M 2013

INSTITUTO DE CIÊNCIAS BIOMÉDICAS ABEL SALAZAR UNIVERSIDADE DO PORTO

\title{
THE ROLE OF MIR-375 IN PROSTATE CARCINOGENESIS
}

PEDRO FILIPE DA COSTA PINHEIRO TESE DE MESTRADO APRESENTADA AO INSTITUTO DE CIÊNCIAS BIOMÉDICAS ABEL SALAZAR DA UNIVERSIDADE DO PORTO EM

ONCOLOGIA MOLECULAR 



\section{THE ROLE OF MIR-375 IN PROSTATE CARCINOGENESIS}

Dissertação de mestrado apresentada ao Instituto de Ciências Biomédicas Abel Salazar da Universidade do Porto em Oncologia - Especialização em Oncologia Molecular

Orientador

Professora Doutora Carmen de Lurdes Fonseca Jerónimo Professora associada convidada com "Agregação" Departamento de Patologia e Imunologia Molecular Instituto de Ciências Biomédicas Abel Salazar Universidade do Porto

Investigadora auxiliar e coordenadora do Grupo de Epigenética do Cancro - Centro de Investigação Instituto Português de Oncologia - Porto

Co-Orientador

Professor Doutor Rui Manuel Ferreira Henrique

Professor auxiliar convidado com "Agregação"

Departamento de Patologia e Imunologia Molecular

Instituto de Ciências Biomédicas Abel Salazar Universidade do Porto

Diretor do Serviço de Anatomia Patológica Investigador sénior Grupo de Epigenética do Cancro Centro de Investigação

Instituto Português de Oncologia - Porto 

"I met a traveler from an antique land Who said: Two vast and trunkless legs of stone Stand in the desert. Near them, on the sand, Half sunk, a shattered visage lies, whose frown, And wrinkled lip, and sneer of cold command, Tells that its sculptor well those passions read Which yet survive, stamped on these lifeless things, The hand that mocked them, and the heart that fed; And on the pedestal these words appear: "My name is Ozymandias, king of kings: Look on my works, ye Mighty, and despair!" Nothing beside remains. Round the decay Of that colossal wreck, boundless and bare The lone and level sands stretch far away."

Percy Bysshe Shelley, Ozymandias, 1818 



\section{AGRADECIMENTOS}

À minha orientadora, Professora Doutora Carmen Jerónimo, um agradecimento muito especial por ter acreditado em mim quando secalhar era mais fácil não o fazer. Por sempre me ter incentivado a ser melhor na parte académica e laboratorial, por todo o apoio quando as coisas correram mal e por nunca me deixar relaxar com o que de bom ia acontecendo. Por ter desenhado um projeto no qual sempre me identifiquei e que conseguimos trazer a bom porto. Pelo conhecimento científico que sempre coloca ao dispor dos alunos! Espero que tenha valido a pena o "investimento" em mim, porque valeu muito a pena dedicar-me a este projeto e ao Grupo! Muito obrigado!

Ao meu co-orientador, Professor Doutor Rui Henrique, por todo o apoio que dá do ponto de vista científico, por todas as dúvidas pertinentes que lançou sobre o desenho e execução do meu projeto, e pela forma como nos prepara cientificamente com todo o seu conhecimento.

Ao Diretor do Serviço de Genética e do Centro de Investigação do Instituto Português de Oncologia do Porto, Professor Doutor Manuel Teixeira, por me ter permitido desenvolver este trabalho no Centro de Investigação do IPO-Porto.

À Filipa, porque chegamos ao Grupo em tempos muito semelhantes e cedo estabelecemos uma relação de amizade. Por todas as conversas científicas sobre os nossos trabalhos, que sem dúvida facilitaram e muito a construção desta tese. Pela tua ajuda na elaboração deste documento tão importante para mim. Pela tua disponibilidade para ajudares na parte da execução prática deste trabalho. Mas acima de tudo, por tudo aquilo que és para comigo e com os outros colegas, um exemplo de profissionalismo e amizade, com quem muito aprendi e muito espero ainda aprender! Um muito obrigado, amiga!

Ao Jorge e à Márcia, porque foram e continuarão a ser os meus estagiários, aqueles que me fazem perguntas chatas mas pertinentes, aqueles que puxam ao máximo por tudo aquilo que sei. Sem dúvida alguma aprendi muito com vocês! Obrigado ao Jorge pela ajuda prática que deu a este projeto em particular, e facilitou-me muito a vida a dada altura!

À Inês e à Elsa, pela vossa amizade e boa-disposição, por poder contar com vocês para a parte prática desta tese, e acima de tudo pelos bons momentos que passamos juntos, momentos de gargalhada constante! 
Ao Diogo Rios, por toda a tua amizade, prontidão em ajudar, seja no que for, pelo teu espírito crítico e pelos momentos de descompressão fora do trabalho. E claro, por me fazeres correr no futebol!

A todos os membros do Grupo de Epigenética do Cancro (atuais e anteriores), pelo ambiente positivo que por norma existe no Grupo e por tudo aquilo que me ensinaram ao longo de todo este tempo, um muito obrigado!

Ao Diogo Silva, porque talvez tenhas sido a pessoa com quem criei maior empatia desde o primeiro momento, porque respeito muito a tua opinião a todos os níveis. Por teres recebido tão bem no Serviço o miúdo de 90! Espero que a nossa amizade perdure por longos e bons anos, sempre com boa-disposição, alegria e muitas futeboladas!

À Joana, muito obrigado por tudo aquilo que me ensinaste, por estares sempre disposta a ajudar, e teres-me ajudado na execução prática desta tese. Tens sido sempre de uma disponibilidade constante, mesmo a aturar as minhas dúvidas em relação aos meus resultados! Pelas discussões pertinentes que tivemos que ajudaram a construir esta tese! Obrigado pela tua verdadeira amizade e paciência!

À Isabel, por aceitares tão facilmente os mais novos, e por todas as vezes em que me ensinaste e alertaste para os erros. Um muito obrigado por tudo aquilo que transmites a quem chega de novo ao Serviço!

A todos os membros do Serviço de Genética, por me terem recebido de forma acolhedora e rápida, e porque de uma forma ou de outra, sempre me foram ensinando coisas durante este percurso.

Aos meus colegas de Mestrado Ricardo, Carlos, Zé, Miguel e Rui, pelas fantásticas aulas e por tudo aquilo que aprendemos juntos sempre com muito boa-disposição.

Aos meus amigos Daniel, Fábio, Miguel e Sara, com quem iniciei o meu percurso académico ainda na Licenciatura, e que sempre se mantiveram presentes na minha vida. Obrigado por me terem facilitado a adaptação ao Porto, e à vida académica, pelos ótimos momentos que fomos tendo que vincaram uma forte amizade entre nós. Muito obrigado!

Aos meus amigos Correia e Diogo, que ainda que longe no sentido físico sempre estiveram presentes. Por ajudarem a descomprimir do trabalho, muito obrigado! 
Ao Hulk, por estar sempre disposto a brincar quando regresso a casa, mesmo quando as coisas não correm tão bem. Nunca pensei vir a agradecer a um gato, mas Hulk, esta Tese também é tua!

À Sofia, por tudo aquilo que me transmites de bom, toda a paciência que tens para mim (eu sei que não sou fácil!). Por ao longo destes anos me teres sempre ajudado com tudo aquilo que fui precisando, e acima de tudo, por me deixares mais tranquilo quando as coisas não correram tão bem e me teres incentivado quando as coisas iam correndo de feição! Sem ti e sem o teu carinho esta Tese não existia! Por caminharmos juntos, esta é uma vitória também tua!

Ao meu irmão, por ser o meu pedestal, aquele que eu nunca vou conseguir alcançar de tão bom que é! És de fato um exemplo, um exemplo que sempre me obrigou a crescer apontando o caminho e indo à frente dando o corpo às balas! Por teres sido sempre presente no percurso escolar desde miúdo, por me teres incluído sempre na tua vida e feito de mim uma pessoa melhor, um muito obrigado Mano!

E como em último vêm sempre os primeiros, aos meus Pais! Por sempre terem acreditado em mim e no meu valor, sempre me terem incentivado a ser o melhor em tudo que ia fazendo. Sem o vosso apoio, compreensão e carinho, não estaria aqui seguramente! Pela exigência, mas sobretudo por estarem sempre presentes, em qualquer situação, um muito obrigado! Até porque, foram os que mais sofreram com os meus insucessos ou preocupações que não me permitiam chegar a casa com a mesma boa-disposição e alegria. Por sempre me terem puxado para cima, muito obrigado! São os melhores Pais do Mundo, disso tenho a certeza!

Esta é para vocês!

Agradeço ainda à Liga Portuguesa Contra o Cancro - Núcleo Regional do Norte, pela bolsa que me concedeu durante o ano de trabalho experimental apresentado nesta dissertação de Mestrado.

Este estudo só foi possível com o financiamento pela Liga Portuguesa Contra o Cancro - Núcleo Regional do Norte, pelo "European Community's Seventh Framework Programme - Grant number FP7-HEALTH-F5-2009-241783" e pelo Centro de Investigação do Instituto Português de Oncologia do Porto (CI-IPOP 4-2008). 



\section{RESUMO}

Introdução: O cancro da próstata é uma doença heterogénea que afecta sobretudo homens dos países desenvolvidos, representando uma das neoplasias mais incidentes em todo o Mundo. Contudo, os processos de iniciação e progressão do cancro da próstata são em grande medida desconhecidos. Assim, um melhor conhecimento nesta área é crucial para uma adequada compreensão e monitorização clínica da doença. Os microRNAs (miRNAs) compõe um campo em crescimento dentro da investigação oncológica, com vários estudos publicados em relação ao seu papel no cancro da próstata. Devido à sua interação com numerosos genes relacionados com a tumorigénese, os miRNAs desempenham um papel crítico no cancro. Assim, compreender como estes miRNAs atuam numa doença tão complexa e incidente como o cancro da próstata é de especial relevância.

Objectivos: O principal objetivo desta Tese foi identificar miRNAs sobreexpressos em carcinoma da próstata. Posteriormente, procuramos caracterizar funcionalmente o papel destes miRNAs na carcinogénese prostática utilizando modelos in vitro.

Material e Métodos: Com recurso a uma plataforma composta por mais de 700 miRNAs obtivemos um perfil de expressão para amostras de cancro da próstata e tecido normal de próstata. De seguida, por RT-qPCR, avaliamos a expressão específica de alguns miRNAs sobreexpressos (miR-32, miR-182 e miR375) num conjunto alargado de amostras. Em relação ao miR-375, realizamos experiências de ganho e perda de função em linhas celulares de cancro da próstata (PC-3 e 22Rv1) e numa linha celular de próstata normal (RWPE-1). Caracterizámos, ainda, quais os efeitos fenotípicos após a transfecção, recorrendo a ensaios de viabilidade celular, apoptose e invasão. Através de uma plataforma personalizada de genes, procuramos potenciais alvos do miR-375 em cancro da próstata, e validámos os mais significativos (RB1, CCND2, CDKN1A e CDK2) numa série alargada de amostras de próstata.

Resultados: Numa primeira abordagem, um total de 17 miRNAs sobreexpressos em cancro da próstata foram encontrados. De seguida, aquando da validação de 3 destes miRNAs, verificamos que tanto o miR-182 como o miR-375 se encontravam sobre-expressos numa maior série de amostras. Relativamente ao miR-375, este encontrava-se sobre-expresso em linhas celulares de cancro da 
próstata comparativamente a uma linha celular normal de próstata, RWPE-1. Após forçar a expressão do miR-375 nesta linha normal, não houve qualquer efeito fenotípico em relação à viabilidade celular e apoptose. A sobre-expressão deste miRNA na linha celular PC-3 aumentou o nível de apoptose e diminuiu a viabilidade celular bem como a capacidade de invasão. Em relação à linha celular 22Rv1, a inibição do miR-375 conduziu a um aumento dos níveis de apoptose e diminuição da viabilidade celular. Conseguimos, ainda, identificar o gene CCND2 com um alvo putativo do miR-375 em cancro da próstata.

Discussão: O miR-182 encontra-se sobre-expresso em cancro da próstata e parece desempenhar um papel oncogénico neste tumor, como previamente reportado por outros. Contudo, não existe ainda uma explicação mecanística para esta sobre-expressão, admitindo-se a hipótese de ser devida a amplificação cromossómica. O nosso estudo associou, ainda, o miR-375 à carcinogénese prostática. Este miRNA encontra-se não apenas sobre-expresso em amostras tecidulares de cancro da próstata mas também nas linhas celulares deste tumor. Após avaliarmos os efeitos fenotípicos das experiências in vitro, postulámos que o miR-375 desempenha um duplo papel no cancro da próstata. Descrevemos ainda o gene CCND2 como um potencial alvo do miR-375 devido à desregulação observada nos estudos in vitro tanto com o precursor como com o inibidor deste miRNA.

Conclusões e Perspectivas Futuras: $O$ miR-375 está envolvido na carcinogénese prostática e está muito provavelmente ligado a várias vias importantes na carcinogénese prostática. Este microRNA aparentemente desempenha um papel duplo dependente do contexto celular, sendo requeridos estudos adicionais para esclarecer o seu envolvimento no cancro da próstata bem como os respectivos genes alvo. 


\section{SUMMARY}

Introduction: Prostate cancer (PCa) is a heterogeneous disease that mostly affects men living in developed countries, representing one of the most incident cancers. There is still limited knowledge about its onset and progression. Therefore, increased knowledge in this area is crucial for a better understanding of the disease and its clinical management. MicroRNAs (miRNAs) are a growing field within cancer research and several studies have been published relating these to PCa. Due to their interaction with numerous cancer-related genes, they play a critical role in tumorigenesis. Thereby, understanding how miRNAs act in such a complex and highly incident disease, such as PCa, is of major importance.

Aims: The main aim of this Thesis was to identify overexpressed miRNAs in PCa. Subsequently we sought to functionally characterize the role of these miRNAs in prostate carcinogenesis, using in vitro models.

Material and Methods: Using a panel of more than 700 miRNAs, we profiled their expression in PCa and morphological normal prostate (MNPT) tissues. Then, by RT-qPCR, we assessed individual expression for overexpressed miRNAs (miR-32, miR-182 and miR-375) in a larger set of tissue samples. Subsequently, we performed gain and loss of function experiments with miR-375 in PCa cell lines (PC-3 and 22Rv1) and a normal prostate cell line (RWPE-1). We characterized the phenotypic effects upon transfection by evaluating cell viability, apoptosis and invasion. Moreover, we used a gene custom array to evaluate miR375 potential target genes in $\mathrm{PCa}$, and then validated the most significant $(R B 1$, CCND2, CDKN1A and CDK2) in a larger set of prostate samples.

Results: We found 17 overexpressed miRNAs in PCa compared to MNPT. Then, we validated 3 of these miRNAs and found that miR-182 and miR-375 were upregulated in a larger set of samples. Regarding miR-375, it was also overexpressed in PCa cell lines comparing with RWPE-1, a normal prostate cell line. After forced expression of miR-375 in RWPE-1, no phenotypic effects on cell viability or apoptosis were apparent. Overexpression of this miRNA in PC-3 cells led to increased apoptosis, diminished invasion ability and cell viability. Loss of function experiments in $22 \mathrm{Rv} 1$ also led to an increase in apoptotic levels and decreased cellular viability. We also identified CCND2 as a putative target for miR375 in PCa. 
Discussion: MiR-182 overexpression in PCa samples suggests an oncogenic role, as previously reported by others. Although, a mechanistic explanation for this upregulation is lacking, we hypothesized that this might be due to chromosomal amplification. Our study also implicates miR-375 in prostatic carcinogenesis. This miRNA is not only overexpressed in PCa samples but also in PCa cell lines. After in vitro experiments and subsequent phenotypic results, we propose that this miRNA might actually play a dual role in PCa. We also described CCND2 as a potential target of miR-375 due to deregulation in PCa cell lines after in vitro studies with precursor and inhibitor molecules of miR-375.

Conclusions and Future Perspectives: MiR-375 is involved in prostatic carcinogenesis and it is most likely related to several key pathways in cancer. This miRNA seems to play a dual role depending on cellular context and further studies focused not only in its involvement in PCa but also on potential targets are mandatory. 


\section{TABLE OF CONTENTS}

INTRODUCTION

1. Prostate 1

1.1. PROSTATE GLAND: ANATOMIC AND HISTOLOGICAL DESCRIPTION

1.2. DISORDERS AFFECTING THE PROSTATE GLAND 2

1.3. Prostate CANCER: A MAJOR EPIDEMIOLOGICAL CONCERN 3

1.4. PROSTATE CANCER: WHICH ARE THE RISK FACTORS SCIENTIFICALLY ESTABLISHED?

1.5. PROSTATE CANCER: GUIDELINES AND TOOLS FOR AN ACCURATE DIAGNOSIS 6

1.6. A GRADING SYSTEM: THE GLEASON SCORE

1.7. Staging Prostate CanCER: Clinical AND Pathologic approach 8

$\begin{array}{ll}\text { 1.8. Therapeutic APPROACHES For Prostate CANCER } & 11\end{array}$

1.9. PROSTATE CANCER: WHAT IS LEFT TO DO?

2. EPIGENETICS

$\begin{array}{ll}\text { 2.1 AN EMERGENT FIELD } & 13\end{array}$

$\begin{array}{lr}\text { 2.2. THE THREE MECHANISMS OF GENE EXPRESSION CONTROL } & 14\end{array}$

3. MICRORNAS 18

3.1. BIOGENESIS: FROM THE NUCLEUS TO THE CYTOPLASM 18

3.2. MODUS OPERANDI: HOW THEY EXERT THEIR FUNCTION? 19

3.3. TARGET PREDICTION: DOWN THE MICRORNA RIVER 20

3.4. MICRORNAS DEREGULATION IN CANCER: A WARNING SIGN 21

3.5. MICRORNAS DEREGULATION: A NEW LAYER ON PROSTATE CANCER COMPLEXITY 23

$\begin{array}{lr}\text { MATERIAL AND METHODS } & 27\end{array}$

1. Clinical SAMPLES

1.1. Patients And Sample Collection 27

$\begin{array}{lr}\text { 1.2. RNA EXTRACTION } & 27\end{array}$

1.3. MICRORNAS CDNA SYNTHESIS 28

1.4. MICRORNAS PANEL: GLOBAL EXPRESSION 29

1.5. MICRORNAS EXPRESSION: INDIVIDUAL ASSAYS 29

2. IN VITRO STUDIES

2.1. Cell Culture 31

2.2. MicRoRNA TRANSFECTION 32

2.3. Cell Viability Assay 33

2.4. APOPTOSIS ASSAY

2.5. INVASION ASSAY 36

2.6. RNA EXTRACTION

2.7. PROTEIN EXTRACTION 38 
3. TARGETS' EXPLOITATION 38

3.1. CDNA SYNTHESIS 38

3.2. CUSTOM EXPRESSION PANEL $\quad 39$

3.3. Gene Ontology EnRICHMENT 39

4. TARGETS' VALIDATION

4.1. CDNA SYNTHESIS: WHOLE TRANSCRIPTOME AMPLIFICATION 40

4.2. EXPRESSION ASSAYS

5. STATISTICAL ANALYSIS

RESULTS 43

1. GLOBAL MiRNAS OVEREXPRESSION IN PCA TISSUES 43

2. VALIDATION OF OVEREXPRESSED MIRNAS 43

3. ASSOCIATION BETWEEN GENES' EXPRESSION AND CLINICOPATHOLOGICAL FEATURES 44

4. MIR-375 EXPRESSION IN PROSTATE CELL LINES 45

5. FORCED EXPRESSION OF MIR-375 IN A NORMAL PROSTATE CELL LINE, RWPE-1, DOES NOT ALTER PROSTATE PHENOTYPE 46

6. OVEREXPRESSION OF MIR-375 IN PC-3: EFFECT ON VIABILITY, APOPTOSIS AND INVASION ABILITY 46

7. MIR-375 SILENCING IN 22RV1: IMPACT ON CELL VIABILITY AND APOPTOSIS 48

8. SEARCHING FOR POTENTIAL TARGETS OF MIR-375 49

9. VALIDATION OF POTENTIAL TARGETS OF MIR-375 51

10. PATHWAYS AFFECTED FOLLOWING MIR-375 DEREGULATION 52

DISCUSSION

CONCLUSIONS AND FUTURE PERSPECTIVES 58

REFERENCES $\quad 59$ 


\section{FIGURES INDEX}

Figure 1. ANATOMY OF THE HUMAN PROSTATE.

Figure 2. PROGRESSION PATHWAY FOR PROSTATE CANCER. 3

Figure 3. CANCER INCIDENCE IN EUROPE AND PORTUGAL, IN MALES.

FiguRE 4. ESTIMATED AGE-STANDARDIZED INCIDENCE RATE PER 100,000. 5

FiguRE 5. MODIFIED GLEASON SCORE SYSTEM FOR HISTOLOGICAL GRADING OF PCA. 8

FIGURE 6. MICRORNAS BIOGENESIS.

FIGURE 7. MICRORNAS MECHANISMS OF ACTION.

FIGURE 8. MICRORNAS DUAL ROLE IN CANCER.

$\begin{array}{lr}\text { FIGURE 9. SPECIFIC MICRORNA CDNA SYNTHESIS. } & 28\end{array}$

FIGURE 10. AMPLIFICATION OF MICRORNAS' CDNA. 30

Figure 11. ChemicAl REDUCTION OF MTT, THE PRINCIPLE OF CELL VIABILITY ASSAY. $\quad 34$

Figure 12. APOPTOTIS EVALUATION USING APOPERCENTAGE ASSAY KIT. 35

Figure 13. PrinCIPLE BEHIND BIOCOAT MATRIGEL INVASION ChAMBER AND SUBSEQUENT

ANALYSIS OF INVASION. 36

FIGURE 14. EXPRESSION LEVELS OF MIRNAS (A) MIR-32, (B) MIR-182 AND (C) MIR-375 AFTER

VALIDATION.

FIGURE 15. MIR-375 EXPRESSION LEVELS IN PROSTATE CELL LINES. 45

FIGURE 16. FORCED EXPRESSION OF MIR-375 IN RWPE-1. 46

FIGURE 17. REEXPRESSION OF MIR-375 IN PC-3.

FIGURE 18. INVASION ASSAY IN PC-3 CELL LINE. $\quad 48$

FIGURE 19. INHIBITION OF MIR-375 IN 22RV1. 49

FIGURE 20. RESULTS FOR GENES INCLUDED IN THE CUSTOM ARRAY NORMALIZED FOR MIR-NC. 50

FIGURE 21. EXPRESSION LEVELS OF POTENTIAL MIR-375 TARGETS FOR ARRAY VALIDATION. 51 


\section{TABLES INDEX}

TABLE 1. TNM StAGing CLASSIFICATION FOR PCA BY THE UICC/AJCC IN 2010.

TABLE 2. SPECIFIC TARGET SEQUENCES FOR MICRORNAS TESTED. 31

TABLE 3. CULTURE MEDIA CONDITIONS FOR PROSTATE CELL LINES. 32

TABLE 4. NUMBER OF CELLS PLATED FOR IN VITRO EXPERIMENTS FOR EACH CELL LINE TESTED. 32

TABLE 5. GENE EXPRESSION ASSAYS.

TABLE 6. OVEREXPRESSED MIRNAS IN MICROARRAY ANALYSIS. CHROMOSOME LOCATION FOR MIRNAS SELECTED FOR FURTHER STUDIES.

TABLE 7. CLINICAL AND PATHOLOGICAL DATA OF PATIENTS INCLUDED IN THIS STUDY. $\quad 45$

TABLE 8. GENES MORE DEREGULATED IN OPPOSITE TRENDS AFTER MIR-375 TRANSFECTION. 51 


\section{LIST OF ABBREVIATIONS}

AFMS Anterior fibromuscular stroma

Ago Argonaute

AJCC American Joint Committe on Cancer

$\boldsymbol{A R} \quad$ Androgen receptor

BCA Bicinchoninic acid

BCL2 B-cell CLL/lymphoma 2

Bim $\quad \mathrm{Bcl}-2$ interacting mediator of cell death

BPE Bovine pituitary extract

BPH Benign prostatic hyperplasia

BSA Bovine serum albumin

BTG2 BTG family member 2

CCND1 Cyclin D1

CCND2 Cyclin D2

CDK2 Cyclin-dependent kinase 2

CDKN1A p21

CIP2A Cancerous inhibitor of PP2A

CRPC Castration-resistant PCa

CTTN Cortactin

DGCR8 Di George Syndrome critical region gene 8

DNMT DNA methytransferase

DRE Digital rectal examination

DTT Dithiothreitol

EGF Human recombinant epidermal growth factor

EGFR Epidermal growth factor receptor

EMT Epithelial-to-mesenchymal transition

Era Estrogen receptor

EZH2 Enhancer of zeste homologue 2

FBS Fetal bovine serum

FDR False discovery rate

FOXF2 Forkhead box F2

FOXO1 Forkhead box 01

GNA13 Guanine nucleotide binding protein (G protein) alpha 13 


\begin{tabular}{|c|c|}
\hline GOE & Gene ontology enrichment \\
\hline GS & Gleason score \\
\hline$G U S \beta$ & Beta-D-Glucuronidase \\
\hline HAT & Histone acetyltransferase \\
\hline HDAC & Histone deacetylase \\
\hline HDAC1 & Histone deacetylase 1 \\
\hline HDM & Histone demethylase \\
\hline HER2 & Erythroblastic leukemia viral oncogene homolog 2 \\
\hline HGPIN & High-grade PIN \\
\hline HMT & Histone methyltransferase \\
\hline IARC & International Agency for Research on Cancer \\
\hline JAK2 & Janus kinase 2 \\
\hline KW & Kruskal-Wallis test \\
\hline lincRNA & large intergenic non-coding RNA \\
\hline InCRNA & Long non-coding RNA \\
\hline $\mathrm{m} 5 \mathrm{C}$ & 5-methyl cytosine \\
\hline$M C L 1$ & Myeloid cell leukemia sequence 1 \\
\hline MDB & Methyl-CpG-binding domain \\
\hline MIM & Missing in metastasis \\
\hline miR-NC & miR-Negative control \\
\hline miRNA & microRNA \\
\hline MNPT & Morphologically normal prostate tissues \\
\hline MRI & Magnetic resonance imaging \\
\hline MTSS1 & Metastasis suppressor 1 \\
\hline MW & Mann-Whitney U test \\
\hline nCRNA & non-coding RNA \\
\hline NDRG 1 & $\mathrm{~N}$-myc downstream regulated 1 \\
\hline ORF & Open reading frame \\
\hline P-S & Penicillin-Streptomycin \\
\hline PBS & phosphate-buffered saline \\
\hline $\mathrm{PCa}$ & Prostate cancer \\
\hline PDCD4 & Programmed cell death 4 \\
\hline PIA & Proliferative inflammatory atrophy \\
\hline PIN & Prostatic intraepithelial neoplasia \\
\hline piRNA & PIWI-interacting RNA \\
\hline pre-miRNA & precursor-miRNA \\
\hline
\end{tabular}




$\begin{array}{ll}\text { PSA } & \text { Prostate-specific antigen } \\ \text { PTEN } & \text { Phosphatase and tensin homolog } \\ \text { RB1 } & \text { Retinoblastoma 1 } \\ \text { RECK } & \text { Reversion-inducing-cysteine-rich protein with kazal motifs } \\ \text { RIPA } & \text { Radio immuno precipitation assay } \\ \text { RISC } & \text { RNA-induced silencing complex } \\ \text { ROCK1 } & \text { Rho-associated protein kinase 1 } \\ \text { RP } & \text { Radical prostatectomy } \\ \text { SAM } & \text { S-adenosyl-methionine } \\ \text { SIRT1 } & \text { Silent information regulator 1 } \\ \text { SNAI2 } & \text { Snail homolog 2 } \\ \text { SNAIL } & \text { Zinc finger protein SNAI1 } \\ \text { SNORNA } & \text { small nucleolar RNA } \\ \text { SNP } & \text { Single nucleotide polymorphism } \\ \text { T-UCR } & \text { Transcribed ultraconserved regions } \\ \text { TFRC } & \text { Transferrin receptor } \\ \text { TRBP } & \text { Trans-activator RNA (tar)-binding protein } \\ \text { TRUS } & \text { Transrectal ultrasound } \\ \text { UICC } & \text { Union for Cancer Control } \\ \text { UTR } & \text { Untranslated region } \\ \text { WHO } & \text { World Health Organization } \\ \text { WNT3A } & \text { Wingless-type MMTV integration site family member 3A } \\ \text { WTA } & \text { Whole transcriptome amplification } \\ \text { XPO5 } & \text { Exportin 5 } \\ \text { ZEB1 } & \text { Zinc finger E-box binding homeobox 1 } \\ \text { ZEB2 } & \text { Zinc finger E-box binding homeobox } 2 \\ & \end{array}$




\section{INTRODUCTION}

\section{Prostate}

\subsection{Prostate gland: anatomic and histological description}

The prostate gland is an exocrine organ located in the pelvic region, which surrounds the urethra and has a walnut shape [1, 2]. In normal conditions, this gland has approximately $25 \mathrm{~cm}^{3}$ and weights about $20 \mathrm{~g}[2,3]$. Prostate is an integral component of male reproductive system, and its main function is to produce crucial components of the seminal fluid [1].

In the twentieth century, researchers tried to divide this gland in lobes as proved in experimental animals. Due to lack of distinguishable lobes in human prostate, a proposal made by McNeal in 1969, that zones instead of lobes should divide the prostate gland, prevailed [1]. Therefore, nowadays it is commonly accepted that there are four distinct zones within a prostate gland: peripheral, central, transition and anterior fibromuscular stroma (AFMS) [3]. The peripheral zone is the main area, comprises about $70 \%$ of the organ and is where most of the prostate carcinomas arise. The central zone has a cone shape and surrounds the ejaculatory ducts that arise from the confluence of the seminal vesicles with the vas deferens on each side. The transition zone is composed of two equal parts of glandular tissue and surrounds the urethra. Age-related benign prostatic hyperplasia (BPH) lesions are frequently limited to this specific region, but occasionally some carcinomas may develop here. The AFMS is an anterior band rich in striated muscle, contiguous with the bladder smooth muscle and the external sphincter. This zone is the clue that sticks the prostate gland to the pelvic diaphragm and bladder neck at the gland's anterior portion. Involving the gland there is a thin layer of fibrous tissue normally referred as prostate capsule (Figure 1) [2, 3].

Histologically, prostate has the architecture of a branched ductal gland each containing two cell layers, a luminal secretory columnar and an underlying basal layer. Rare neuroendocrine cells are also observable in normal epithelium of prostate glands [2, 3]. 


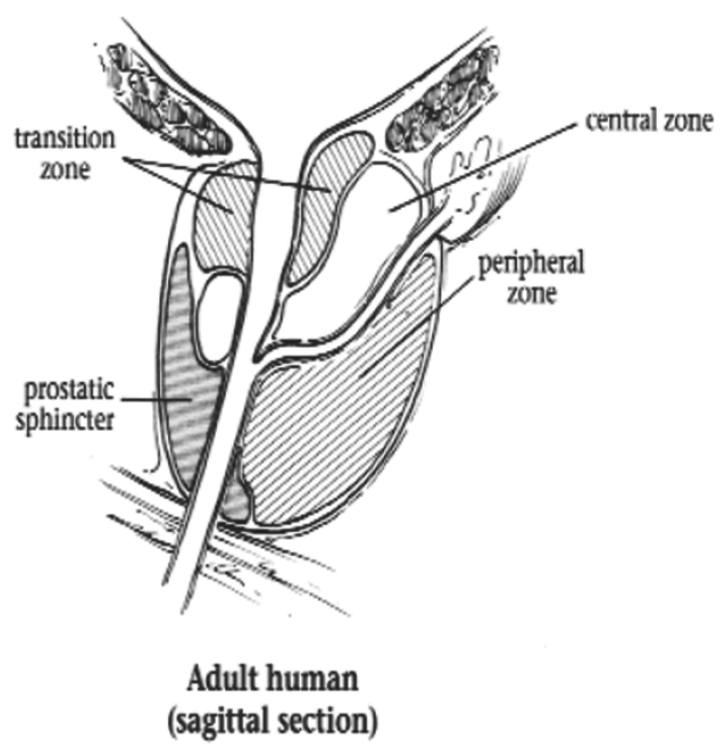

Figure 1. Anatomy of the human prostate (adapted from [4]).

\subsection{Disorders affecting the prostate gland}

Prostate disorders are very common with increasing age and are major health concerns, especially in an aging world population [5]. In fact, regarding men autopsied in the eighth decade of life, there are more than $90 \%$ of individuals with benign alterations and more than $70 \%$ with malignant disorders [6]. Pathologic conditions distressing prostate are very diverse including both benign and malign conditions.

Benign prostatic hyperplasia is a common disease, affecting around $50 \%$ of men over 50 years old [5]. From those, 75\% develop symptoms related to increase of prostate size and volume [7]. BPH is a chronic disease, highly linked to age, but still without a clear connection with prostate cancer (PCa) onset and progression.

However, there are prostatic pathological conditions that are most likely precursors of PCa. Prostatic intraepithelial neoplasia (PIN) has a characteristic presence of atypical epithelial cells but normal prostatic acini architecture is present $[2,8]$. Histologically PIN is divided as low- and high-grade (HGPIN) but only the latter is considered as potential precursor for PCa [2, 8]. HGPIN lesions exhibit higher levels of cellular proliferation markers and prominent nucleoli proving its ability to progress towards a prostate carcinoma. Despite HGPIN also presents basal cells, which are absent in PCa and are important for a differential diagnosis between these two identities and also validates HGPIN as an intermediate stage between normal and cancer of prostate tissues $[1,8]$. Interestingly, HGPIN share some common features with PCa, such as: 
epidemiologic (both have increased prevalence with aging), topographic (proximity of about $70 \%$ in prostatectomy samples), morphologic and genetic alterations (atypia, chromosomal aberrant patterns) [9]. Both lesions are multifocal and heterogeneous, again pointing to a strong relation between HGPIN and PCa [10].

Proliferative inflammatory atrophy (PIA) has been suggested as a precursor of HGPIN, an ancient step in prostate carcinogenesis, although its premalignant potential has yet not been fully determined [9].

Last in the process, first in health concern; prostate adenocarcinoma accounts for $95 \%$ of prostatic malignant conditions and has no specific symptoms, which leads generally to a late diagnosis [3] and range from clinically indolent to extremely aggressive neoplasms [3]. In PCa, tumor cells do not retain their basal cell layer, more interestingly, this feature is lost progressively trough an evident path from BPH, to HGPIN and finally PCa, suggesting some type of ancestry between these lesions (Figure 2) [11].

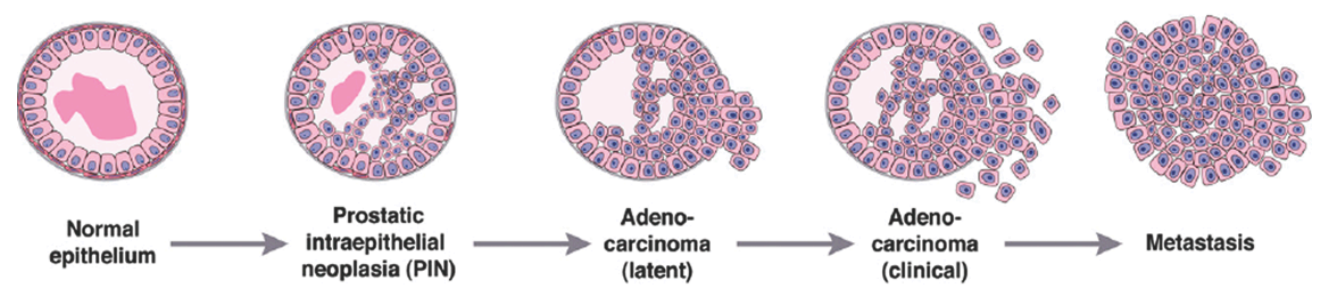

Figure 2. Progression pathway for prostate cancer (adapted from [1]).

Therefore, there is still a lot to understand and explore, regarding how prostate cancer evolves and if this potential relationship is true or just artifact of such a complex cancer model.

\subsection{Prostate cancer: a major epidemiological concern}

Amongst men worlwide, PCa is the second most common neoplasia, only outshined by lung cancer. This fact is even more evident when restricting analysis to European men, where PCa is the most incident neoplasm and is the fourth leading cause of cancer death. In 2008, 899,000 new cases occurred across the World, accounting for $13.6 \%$ of total newly diagnosed cancers. Regarding statistics for PCa in Portugal, 5140 new patients were diagnosed in 2008 being the most frequent neoplasia among men (21.4\% of total) ranking third in cancer mortality (13.7\% of total cancer cases) (Figure 3) [12] 


\section{Incidence}

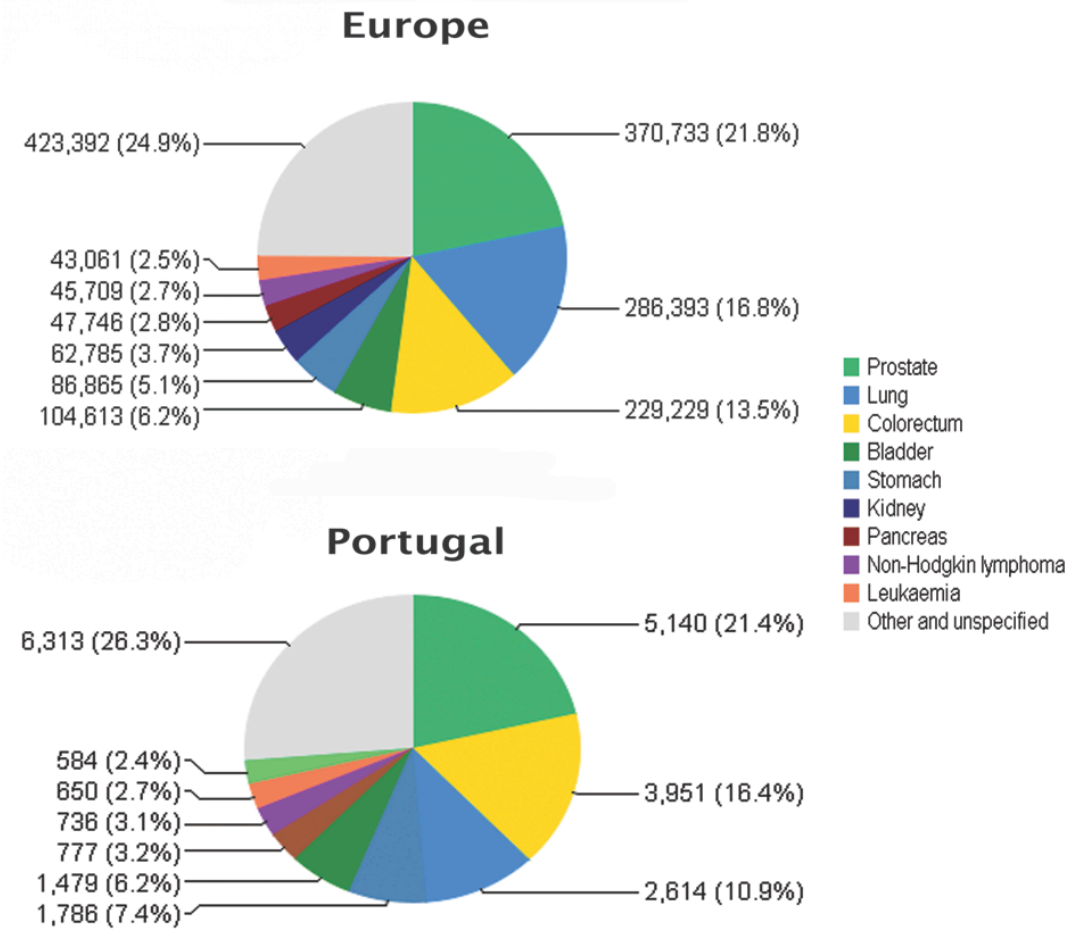

Figure 3. Cancer incidence in Europe and Portugal, in males (adapted from [12]).

Specifically, PCa is the most frequent malignancy in developed regions presenting extremely variable incidence rates around globe regions. Incidence can vary by more than 25-fold worldwide as recorded by International Agency for Research on Cancer (IARC) in 2008. This variance may be explained primarily by abyssal differences in age structure between populations of different regions, which cannot be controlled even with age standardization techniques [9]. Other reasons may account for this difference, such as detection techniques and screening programs, such as prostate-specific antigen (PSA) test [13]. Since introduction of this screening test in the second half of the 80 's, incidence rates rose rapidly in countries that adopted this test. Nowadays, numbers of newly diagnosed cases is stable even presenting a slight reduction [14]. If PSA test may explain differences in incidence rates between regions, it does not seem to play an important part in mortality rates [15]. Mortality rate has a 10-fold variance between developed and developing regions, which is not consistent with differences in incidence brought by introduction of the PSA screening method (Figure 4) [16]. Once more, this difference probably occurs due to different age structure in populations from these countries. 


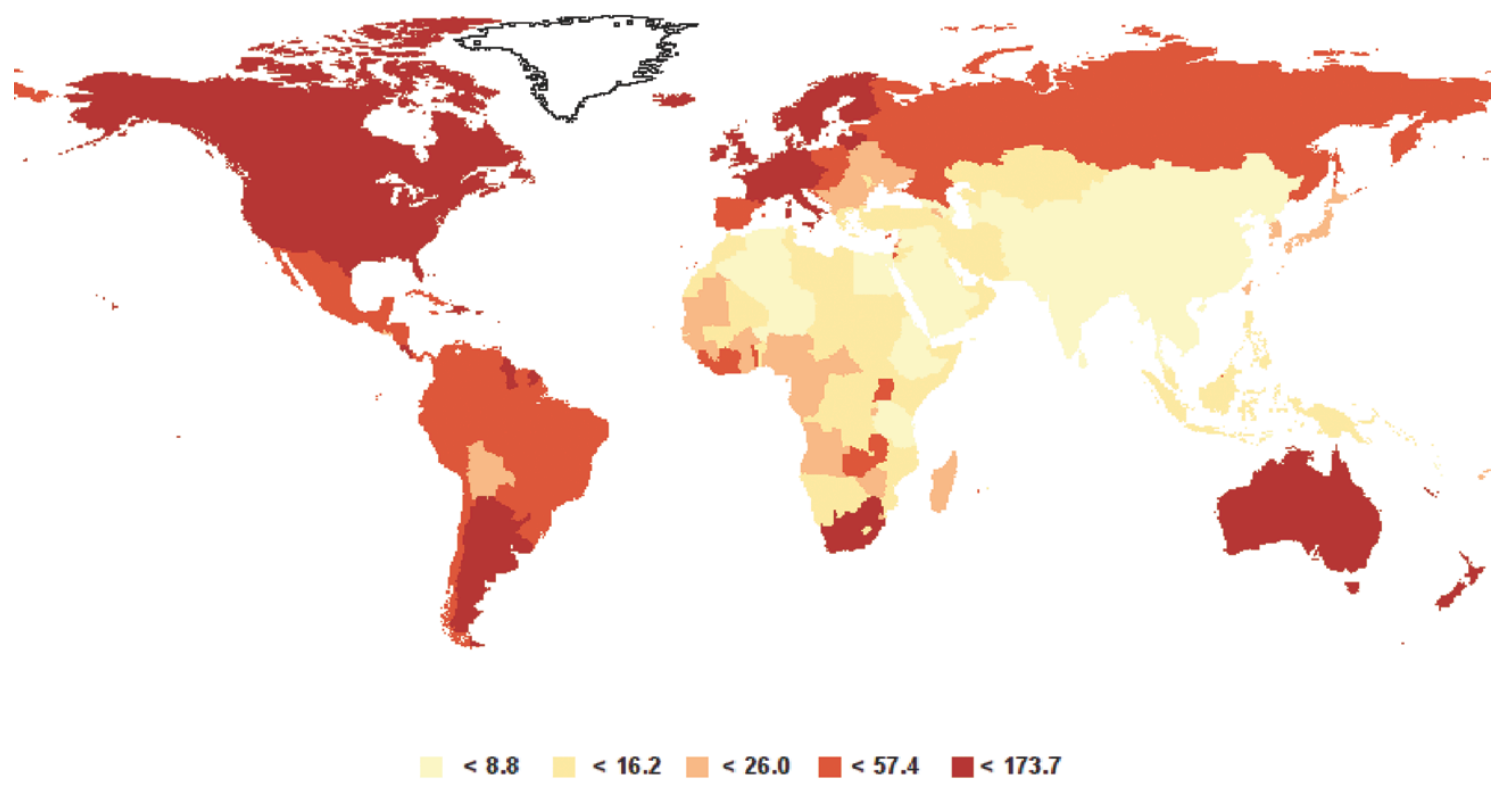

Figure 4. Estimated age-standardized incidence rate per 100,000 (adapted from [12]).

\subsection{Prostate cancer: which are the risk factors scientifically established?}

In contrast to other neoplasias, and despite several attempts from scientific community, there are only three risk factors clearly connected to PCa: family history, ethnicity and age [17].

Family history of PCa increases men's probability of developing the disease, suggesting existence of inherited or genetic factors associated with PCa. Recent reports show that $5-10 \%$ of total prostate cancers are related to familiar clusters [15]. In fact, this may also be explained not only by genetic predisposition but also by exposure to the same environmental factors, which eventually lead to development of PCa.

Race is a well-established risk, however without a clear explanation. In fact, PCa is the most unequal cancer regarding incidence between ethnic groups: African American men have higher chance of being diagnosed, generally are diagnosed earlier and at a more advanced stage when compared with Caucasian counterparts [18]. Unfortunately, there are no data available concerning incidence trends for the African continent [17], which might clarify this racial disparity not only in the United States but also worldwide. Genetic, environment, culture and socioeconomic differences may play a role on this unbalanced distribution of PCa incidence, but there are no definitive conclusions yet [15]. The third established 
PCa risk factor is age. Indeed, PCa normally affects older men as a result of disease's latent progress [19]. Actually, age is the most important established risk factor for both PCa incidence and mortality [15]. Disorders affecting prostate gland have their incidence increased with aging: in the ninth decade of life their incidence is higher than 90\% [20].

Intriguingly, all these three risk factors are inevitable, leaving little scope of action on preventing this disease.

\subsection{Prostate cancer: guidelines and tools for an accurate diagnosis}

PCa is normally asymptomatic until invasion occurs, demanding the need of implementation of screening methods on a population basis. PSA test and digital rectal examination (DRE) are commonly used in clinical practice to assist clinicians on screening and future therapeutic options [21]. However, both tests are fallible even when used in combination, and suggested guidelines are revised frequently by health agencies in order to improve this screening procedures accuracy. Currently, and in accordance with international guidelines, men with abnormal DRE result and/or PSA test equal or above $4 \mathrm{ng} / \mathrm{mL}$ must be considered for prostate biopsy $[22,23]$. Screening must start at age of 50 and it must be regular throughout the years until the seventh decade of life [23]. Regarding prostatic biopsy, European guidelines suggest that in a $30-40 \mathrm{mg}$ organ, eight cores must be obtained at least. The number of collected cores must be adapted depending on patient's age, PSA level and prostate volume [24].

Presently, after abnormal results from one or both tests, a patient must be submitted to prostate biopsy to determine presence of PCa [23]. Patients with high levels of PSA and/or an inconclusive and suspicious DRE are considered for transrectal ultrasound (TRUS)-guided systemic biopsy, the gold standard method to obtain prostatic tissue for histological examination. Factors such age, potential morbidity and subsequent therapeutic consequences must be taken into account [24].

PSA screening test was first implemented in 1987, and in subsequent years incidence rates skyrocketed in the United States [25]. PSA is a glycoprotein with protease activity produced by epithelial cells surrounding prostate acini and ducts. This protein is secreted in the lumina of these ducts and is normally present in the plasma, except when disruption of prostate structure (i.e., inflammation, hyperplasia, cancer) leads to its increased presence [9]. Despite PSA being prostate specific it is not prostate cancer specific, which results in 
reduced accuracy for this test [26]. Notwithstanding the exceptional help provided by PSA test for PCa management by clinicians, its nonspecificity has led to overdiagnosis and overtreatment of indolent tumors [27]. Nevertheless, DRE and PSA together as early detection tools have allowed diminishing stage at detection in the last years, as $70-80 \%$ of PCa now diagnosed are organ confined and with increased chances of cure [2].

\subsection{A grading system: the Gleason Score}

Back in 1966, Donald F. Gleason proposed a grading system for PCa that almost five decades later is still the most used remaining as an important tool for prognostic ascertainment [28]. Gleason grading system, with its adaptations, remains as a relevant powerful prognostic predictor for PCa decades after its implementation. According to the World Health Organization (WHO), it enables the prediction of PCa natural history and assessment of recurrence risk after radical prostatectomy (RP) or radiotherapy [22]. Indeed, this grading system was updated and revised throughout the years, being the most recent the consensus obtained in 2005 by the International Society of Urological Pathology [28]. This grading system possesses the particularity of being based solely on the architectural feature of the tumors, excluding cytologic aspects from the analysis [29]. Gleason grading system is composed of a scale from 1 to 5 that reflects progressive loss of glandular structures and stroma invasion [3, 9]. Briefly, pattern 1 has the highest degree of differentiation with discrete glandular formation and pattern 5 shows complete loss of differentiation with subsequent loss of glandular architecture (Figure 5) [2].

Donald F. Gleason was also aware of PCa morphological heterogeneity, because within a single tumor more than one type of grade can be found [28]. Interestingly, it is supposed that over $50 \%$ of PCa have at least portions of three different Gleason grades [22]. Hence, he proposed that this evaluation should be based on the two most frequent architectures present. The sum of both grades is reported as the Gleason score (GS), which can range from $2(1+1)$ to $10(5+5)$ [30]. Alterations to the system reflect clinical practice evolution throughout the years and are an attempt to control flaws in the original grading system. Interobserver discrepancies, most likely due to experience level, are still the major pitfall in using CS $[3,29]$. Recent studies point to a $20 \%$ increase in inter-observer reproducibility with GS modified system [28]. Another issue resides in the PSA 
era, as tumors are diagnosed earlier and most have a GS of 6-7, intermediate categories, limiting the potential use of a 10-point GS as a prognostic tool [3]. In fact there has been a trend to upgrade tumors' GS as proved by new analysis of old PCa specimens [2].

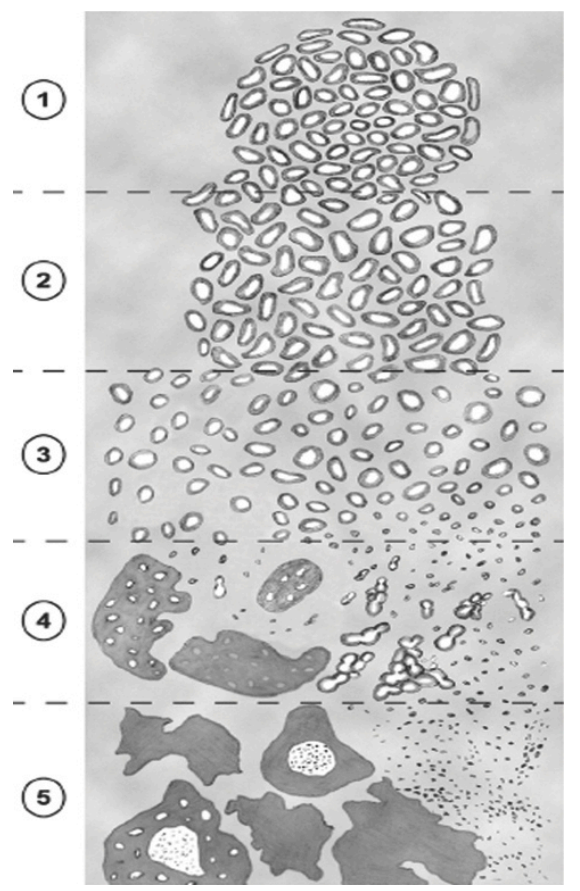

Figure 5. Modified Gleason Score system for histological grading of PCa (adapted from [30]).

\subsection{Staging Prostate Cancer: clinical and pathologic approach}

Over the years, knowledge and evidences have been collected regarding PCa resulting in the establishment of staging systems that allow prognosis evaluation and ascertain tumor development [3]. A global agreement concerning the application and definition of a stage system is crucial for a worldwide approach against cancer. Staging systems must be as accurate as possible due to their unique ability not only to predict prognosis but also to better plan how to treat cancer patients [31]. The American Joint Committee on Cancer (AJCC) and the International Union for Cancer Control (UICC) maintain the most commonly used staging system around the World: the TNM system [32]. This abbreviation consists of the extension of primary tumor $(T)$, presence and extension of involved lymph nodes (N) and distant metastases (M) [9] and offers a "stage grouping" based on $\mathrm{T}, \mathrm{N}$ and $\mathrm{M}$ [32]. AJCC and UICC determined two types of staging considering timing of data collection (Table 1) [33]. Thereby, clinical staging reports to any information on cancer extension before definitive 
treatment onset and remains unchanged apart of the pathologic stage. Concerning PCa, clinical staging is ascertained mainly by DRE examination but also by TRUS and magnetic resonance imaging (MRI). Serum PSA level is also a tool to help on the establishment of clinical stage for PCa [34].

Pathologic staging is obtained after radical prostatectomy (RP) and is centered in macro and microscopic examination of the surgical specimen and dissected regional lymph nodes [2, 33, 34]. Considering extent of disease outside of prostate organ, $\mathrm{N}$-staging is assessed by pelvic lymphadenectomy, while $\mathrm{M}$ staging is obtained by bone scan, however this is only recommended to patients in higher risk (i.e. symptomatic or asymptomatic patients with PSA concentration above $20 \mathrm{ng} / \mathrm{mL}$ and GS of 8 or higher) [13]. Pathologic staging is a relevant ancillary tool to predict recurrence and also a prognostic factor helpful in determining the best follow-up approach for each patient [34]. Throughout the years, clinicians developed nomograms with independent factors to assess prognosis and risk for PCa. These independent prognostic factors include invasion into or through the prostate capsule, preoperative serum PSA levels, GS for the RP specimen, positive surgical margins, lymph node metastases, seminal vesicles involvement and distant metastases [2]. 
Table 1. TNM staging classification for PCa by the UICC/AJCC in 2010 (adapted from [32]).

\begin{tabular}{|c|c|}
\hline \multicolumn{2}{|c|}{ PRIMARY TUMOR (T) } \\
\hline $\mathbf{T X}$ & Primary tumor cannot be assessed \\
\hline TO & No evidence of primary tumor \\
\hline T1 & $\begin{array}{l}\text { Clinically inapparent tumor neither palpable nor visible by } \\
\text { imaging }\end{array}$ \\
\hline T1a & $\begin{array}{l}\text { Tumor incidental histologic finding in 5\% or less of tumor } \\
\text { ressected }\end{array}$ \\
\hline $\mathrm{T} 1 \mathrm{~b}$ & $\begin{array}{l}\text { Tumor incidental histologic finding in more than } 5 \% \text { of tumor } \\
\text { ressected }\end{array}$ \\
\hline T1C & Tumor identified by needle biopsy \\
\hline T2 & Tumor confined within prostate gland \\
\hline $\mathrm{T} 2 \mathrm{a}$ & Tumor involves one half of one side or less \\
\hline $\mathrm{T} 2 \mathrm{~b}$ & $\begin{array}{l}\text { Tumor involves more than one half of one lobe but not both } \\
\text { lobes }\end{array}$ \\
\hline T2C & Tumor involves both lobes \\
\hline T3 & Tumor extendes through prostate capsule \\
\hline T3a & Extracapsular extension (unilateral or bilateral) \\
\hline $\mathrm{T3b}$ & Tumor invades seminal vesicle(s) \\
\hline T4 & $\begin{array}{l}\text { Tumor is fixed or invades adjacent structures other than } \\
\text { seminal vesicles, such as: external sphincter, rectum, bladder, } \\
\text { levator muscles, and/or pelvic wall }\end{array}$ \\
\hline \multicolumn{2}{|r|}{ PATHOLOGIC (PT)* } \\
\hline pT2 & Organ confined \\
\hline $\mathrm{pT} 2 \mathrm{a}$ & Unilateral, one half of one side or less \\
\hline pT2b & $\begin{array}{l}\text { Unilateral, involving more than one half of one lobe but not } \\
\text { both lobes }\end{array}$ \\
\hline pT2c & Bilateral disease \\
\hline pT3 & Extraprostatic extension \\
\hline pT3a & $\begin{array}{l}\text { Extraprostatic extension or microscopic invasion of bladder } \\
\text { neck }\end{array}$ \\
\hline pT3b & Seminal vesicle invasion \\
\hline pT4 & Invasion of rectum, levator muscles and/or pelvic wall \\
\hline \multicolumn{2}{|c|}{ REGIONAL LYMPH NODES (N) } \\
\hline$\overline{N x}$ & Regional lymph nodes were not assessed \\
\hline No & No regional lymph node metastasis \\
\hline N1 & Metastasis in regional lymph node(s) \\
\hline \multicolumn{2}{|c|}{ PATHOLOGIC (PN) } \\
\hline$\overline{p N x}$ & Regional nodes not sampled \\
\hline pNO & No positive regional nodes \\
\hline pN1 & Metastasis in regional node(s) \\
\hline \multicolumn{2}{|c|}{ DISTANT METASTASIS (M) } \\
\hline MO & No distant metastasis \\
\hline M 1 & Distant metastasis \\
\hline Mla & Non-regional lymph node(s) \\
\hline $\mathrm{M} 1 \mathrm{~b}$ & Bone(s) \\
\hline M1c & Other site(s) with or without bone disease \\
\hline
\end{tabular}

*There is no pathologic pTl classification 


\subsection{Therapeutic approaches for Prostate Cancer}

Bearing in mind that PCa is a complex and heterogeneous disease it is difficult to determine standard treatment options for all patients. Clinicians must pay attention to patient and disease's features, such as: age, life expectancy, life quality, TNM classification, GS and preoperative serum PSA level, to determine the best treatment options [9]. The key challenge for the medical/scientific community is to distinguish men with aggressive local disease from whom treatment might change natural history of PCa and spare the other patients from unnecessary treatment morbidity [2].

\subsubsection{Localized disease: treatment options}

\section{Active surveillance}

Active surveillance is a strategy adopted for good-risk patients, where patients are not treated but kept under following and treated when risk of progression increases during follow-up period [24]. Such approach is an attempt to avoid patients' overtreatment and to apply curative therapy procedures only to selected cases [2]. There are defined criteria to decide which PCa patients are eligible for this treatment: clinically confined PCa (T1-T2), GS equal or less than 6 and PSA serum level less than $10 \mathrm{ng} / \mathrm{mL}$ [24]. These patients are subjected to frequent PSA evaluation and prostatic biopsies at 2, 5 and 10 years [9]. In order to ascertain if tumors are in progression phase, some features are essential: PSA above $10 \mathrm{ng} / \mathrm{mL}$ and GS after re-biopsy of 7 or more in a 1 to 4 years interval [24].

\section{Radical prostatectomy}

Radical prostatectomy stands as the only treatment option for localized PCa related with survival benefits comparing with conservative measures [9]. This procedure is offered to men with localized PCa (cT1a-T2b, Gleason score 2-7 and PSA inferior to $20 \mathrm{ng} / \mathrm{mL}$ ), life expectancy of 10 or more years and its intent is to totally eradicate disease $[9,24]$. Nowadays, RP has evolved and its main goal is first to remove the entire cancer but also to preserve normal continence and potency [2]. Recently, cryosurgical ablation of the prostate has emerged as alternative options for patients with clinically localized PCa not eligible for RP [24]. 


\section{External-beam radiotherapy \& Brachytherapy}

Beyond RP efficiency in patients' survival, external-beam radiotherapy and brachytherapy have achieved rates of disease-free survival similar to those obtained by RP [35]. Regarding external-beam radiotherapy, this procedure has lower morbidity rates, which enables its application to broad range of PCa patients, whom do not endure RP or brachytherapy [35]. Concerning brachytherapy, it allows a more localized distribution of radiation resulting in fewer side effects than external-beam radiotherapy [35]. Brachytherapy is typically administrated in patients harbouring localized PCa, with low-volume and low-grade [35]. In patients with intermediate to high-risk disease, combined therapy of external-beam therapy and brachytherapy is frequently used leading to good survival rates [2].

\subsubsection{Advanced disease: which options remain? Hormonal therapy}

The year was 1941 when Huggins and Hodges first reported the benefits of surgical castration in metastatic PCa, also showing that PCa is at some point androgen dependent [36]. Prostate is a hormone-responsive gland [35] and this fact is the basis behind hormonal therapy, leading to androgen deprivation either by surgical castration, suppressing secretion of androgens or inhibiting its action [36]. Such strategies became the core for advanced PCa management, and recently more centers are trying to implement this strategy in patients with earlier stages of PCa [9]. In fact, recent studies demonstrated that hormonal therapy combined with external beam-radiotherapy and administered to local PCa present high success rates of cure [35].

Despite some problematic side effects, androgen deprivation conduced to symptom relief in $70-80 \%$ of treated patients [13]. Although hormonal therapy enables effective control of symptoms in advanced disease, almost all patients will progress and become resistant to androgen suppression, castration-resistant PCa (CRPC), [37] after 18 to 24 months of hormone treatment [38]. CRPC is the final stage of PCa, where morbidity and mortality rates increase substantially [13]. Traditional chemotherapy protocols are generally innefective to treat CRPC with a response rate of 10-20\% [37] and survival time of only 2 months (docetaxel combined with either prednisone or estramustine) [38]. In fact, and knowing that metastatic PCa is incurable, treatment is only intended tend to be directed to improve patients' life quality. 


\subsection{Prostate cancer: what is left to do?}

In recent decades much has been done to better understand this complex and heterogeneous disease. Some consensuses were achieved in crucial areas, such CS and staging that promotes standardization throughout the globe. Nevertheless, concerning therapeutic strategies applied, there is a wide variation across regions even within the same continent [39]. An attempt should be made to standardize efforts for PCa treatment. There is also an urgent need to develop new and better therapeutic options. This goal can only be accomplished with increased knowledge on the biology of PCa carcinogenic pathways. In recent years, epigenetic mechanisms have emerged as critical players, thus, a better understanding of this area in PCa might help in the goal above described.

\section{EPIGENETICS}

\subsection{An emergent field}

In 1939 C.H. Waddington first coined the term "epigenetics" which derives from the Ancient Greek epi - what stays beyond - genetics [40]. Waddington defined epigenetics as "the causal interactions between genes and their products, which bring the phenotype into being" [40], emphasizing the role of cell environment together with genes to determine final state of an individual. The concept has evolved and nowadays it is defined as the study of mechanisms that initiate and maintain patterns of gene function and regulation in a heritable manner without affecting nucleotide sequence [41]. Those heritable changes occur and are established throughout differentiation and are maintained across cell cycles, and are the reason for cells with the same genetic information give rise to cell lineages with different functions within the same organism [42].

The field of epigenetics comprises three different mechanisms of gene expression regulation, namely: DNA methylation, covalent modifications of histones and non-coding RNAs [41]. These three components together constitute the epigenome machinery whose role is to define which information is available for transcription and translation [43]. Epigenetic patterns are different in space and time through development stages and processes, and deregulation of the established patterns conduces to disease onset [40]. 


\subsection{The three mechanisms of gene expression control}

\subsubsection{DNA methylation}

Concerning epigenetic modifications in humans, DNA methylation is the most widely studied and consequently for which there is more solid data [44]. In mammals, DNA methylation occurs typically by addition of a methyl group at the 5' position of a cytosine ring inside CpG dinucleotides [45]. This phenomenon originates a base named 5-methyl cytosine ( $\mathrm{m} 5 \mathrm{C}$ ) [46]. These $\mathrm{CpG}$ sites are not randomly distributed across the genome, yet they are concentrated at 5'-gene regulatory region, known as CpG islands [47]. In order to be denominated a CpG island, a stretch needs to obey some criteria: 200 or plus bases, CG content of $50 \%$ at least and ratio of observed/expected CpG frequency of at least 0.6 [44]. More importantly, about $60 \%$ of human gene promoters contain a CpG island [48], which are usually unmethylated in normal cells [44]. Some of these regions become methylated through development in a tissue-specific manner, which results in gene silencing, such as imprinted genes and X-chromosome inactivation [42].

Methylation is carried out by a group of enzymes denominated DNA methyltransferases (DNMTs) [47]. This enzymatic reaction needs recruitment of Sadenosyl-methionine (SAM) as a methyl group donor by DNMTs [49]. Nowadays, two different types of DNMT activity have been found: de novo DNMTs (DNMT3A and DNMT3B) and maintenance DNMTs (DNMT1) [44]. DNMT1 is the main responsible for conserving existing methylation patterns in cells after DNA replication [45] exhibiting higher preference for hemimethylated DNA [44]. DNMT3A and DNMT3B are de novo methyltransferases, whose targets are unmethylated CpGs [45], which act autonomously from DNA replication with equal preference for hemi- and unmethylated DNA [42]. These enzymes are highly expressed in early development, particularly in embryonic stem cells [44] and are crucial for defining DNA methylation patterns at this stage [47]. DNA methylation is associated with repressive states of chromatin organization and subsequently inhibition of gene expression [44]. Hereupon, DNA methylation is responsible for gene expression control, although exerts its function by different mechanisms. It may act directly by avoiding binding of transcription factors specific for the gene [45] and/or indirectly by recruiting methyl-CpG-binding domain (MBD) proteins, which in their turn promote recruitment of histonemodifying and chromatin-remodeling complexes [44]. 
Once established its importance in cellular and gene expression context, it is clear that somehow DNA methylation patterns must be deregulated in diseases, especially in cancer. In fact, several studies throughout last two decades resulted in broad knowledge regarding DNA methylation in cancer. All reports concluded that changes in methylation patterns are present in tumors pointing this out as a common element in tumor biology with significant impact on tumor pathology [50]. Tumor cells are characterized by global loss of DNA methylation (20-60\%) [44], particularly in repetitive DNA sequences, coding regions and introns [40]. This loss of methylation contributes to malignant phenotype by promoting: chromosomal instability, reactivation of transposable elements and loss of imprinting [40]. Along with global hypomethylation, there is also hypermethylation at specific $\mathrm{CpG}$ islands, mainly in promoter regions of tumor-suppressor genes [40,44]. By inhibiting expression of crucial genes to a normal phenotype establishment, specific hypermethylation promotes tumor onset and development.

Currently, there is an attempt to transfer the knowledge about these DNA methylation aberrant alterations to the clinical practice either as diagnostic or prognostic biomarkers, or as therapeutic targets due to their reversibility [43].

\subsubsection{Covalent histone modifications}

Eukaryotic genomes are closely enfolded around nucleosomes, which are the basic unit of chromatin [51]. Chromatin is a macromolecular complex consisting of DNA and histone proteins [52]. This structure is essential to mantain genome inside cell nucleus, and also to control protein access for transcription, replication and repair of DNA molecules [51]. Nucleosomes, which are the functional elements of chromatin, are themselves an octamer composed of eight pillars: two each of the histones $\mathrm{H} 2 \mathrm{~A}, \mathrm{H} 2 \mathrm{~B}, \mathrm{H} 3$ and $\mathrm{H} 4$, linked by $\mathrm{H} 1$ [52]. Around this packaging structure, there are $147 \mathrm{bp}$ of DNA wrapped twice around octamers [52, 53]. Chromatin is not a static construction; actually it varies between two completely distinct states: heterochromatin, most commonly containing inactive genes due to its highly package conformation, and a more relaxed form, euchromatin, associated with active transcription [52]. Such differential arrangement, together with nucleosomes experiencing several structural alterations both at DNA wrapping level and histone core assembly along time and space (transcription regulation), demonstrate that histones are very dynamic [53]. Histone proteins present a globular C-terminal domain and an 
unstructured N-terminal tail [54]. By the year of 1961, Vincent Alffrey found that histones undergo post-translational modifications in their N-terminal tail [55]. Since then, it is accepted that these $\mathrm{N}$-tail modifications affect chromatin structure [55]. Post-translational modifications include methylation, acetylation, phosphorylation, ubiquitylation and sumoylation of specific residues [51,54]. Of these, the best well-known, and more studied, are histone acetylation and methylation.

Histone acetylation at lysine residues was the first modification to be described and is the most studied [56]. A family of enzymes, histone acetyltransferases (HATs), carries out this alteration, and another family, histone deacetylases (HDACs), opposes its effects [55]. The mechanisms beyond acetylation suggest a role in gene expression promotion [51]. Acetylation, by neutralizing positive charge of lysine residues, weakens interactions between histones and DNA, conducing to augmented access of DNA to transcription machinery [51]. Therefore, acetylation leads to an open conformation of chromatin [53] and a balance between HATs and HDACs activity is essential for a correct development and cellular stability [57].

Recently, histone methylation received much attention due to lack of understanding. Methylation can occur in lysine (mono-, di- or trimethylation) or arginine (mono- or dimethylation) residues [51]. Unlike acetylation, methylation does not alter lysine positive charges [55], and is much more complicated to understand its consequences for DNA transcription. In fact, histone methylation can lead either to transcription repression by heterochromatin fostering and Polycomb silencing (lysine 9 of histone 3- H3K9, and lysine 27 of histone 3H3K27) or gene activation (trimethylation of both lysine 9 and 36 of histone 3 H3K4me3, H3K36me3) [51]. Two different families of enzymes control histone methylation: histone methyltransferases (HMTs) that are responsible for addition of methyl groups to residues, and histone demethylases (HDMs) that can reverse such change [55]. Histone methylation needs further scrutiny for a better comprehension of its involvement in chromatin regulation, due to its complexity. A correct interplay between HMTs and HDMs is imperative for a normal cellular phenotype [57].

Post-translational modifications being such key mechanisms for gene regulation have been found deregulated in cancer [57]. Abnormalities in this epigenetic mechanism contribute to cancer initiation and progression in two different paths: alteration on normal gene expression patterns for both tumor 
suppressors and oncogenes and genomic instability [55]. Due to its reversible nature, aberrant histone modifications in cancer have been target for development of the so-called "epigenetic drugs", and in fact some of those are already in advanced phases in clinical trials [55].

\subsubsection{Non-coding RNAs}

Regarding human genome, only $2 \%$ encodes for proteins but about $90 \%$ is transcribed into RNA molecules [58, 59]. In the last years, particular emphasis has been given to this non-coding RNAs (ncRNAs). In fact, nowadays it is established that they can be divided by their size in microRNAs $(\sim 22$ nucleotides), small non-coding RNAs (30-300 nucleotides) and long non-coding RNAs (300-several kilobases) [58]. NcRNAs as a group includes different classes, depending on interactions and activity, namely: small nucleolar RNAs (snoRNAs), PIWI-interacting RNAs (piRNAs), transcribed ultraconserved regions (T-UCRs), large intergenic non-coding RNAs (lincRNAs), long non-coding RNAs (IncRNAs) and the spotlight within the group, microRNAs (miRNAs) [60].

Initially ncRNAs were thought to be non-functional but recent studies showed that they are not only functional but also essential to a correct development [60]. Small RNAs are responsible for mediation of posttranscriptional gene silencing of their target RNA transcripts [61]. Regarding IncRNAs, these are involved in high-order chromosomal dynamics, telomere biology and subcellular structural organization [62]. Therefore, it seems that ncRNAs are related to epigenetic mechanisms, such as transposon control, DNA methylation, X-chromosome silencing in females and DNA imprinting [63].

Due to their functional importance within cellular context, it is evident that ncRNAs must be deregulated in human diseases, particularly in cancer. Indeed, once their role in disease onset and development was exposed new potential diagnostic biomarkers and therapeutic targets emerged [59]. Considering cancer, miRNAs involvement has been the most studied throughout the last years resulting in an information boom [60]. 


\section{MICRORNAS}

\subsection{Biogenesis: from the nucleus to the cytoplasm}

Non-coding RNAs have emerged in the spotlight of epigenetics, and studies regarding these molecules have been published rampantly. Inside this vast field, main interest has been given to microRNAs as previously referred. MiRNAs are small molecules of 21-24 nucleotides first discovered in Caenorhabditis elegans, in 1993 [64]. Soon, researchers realized that these molecules are well conserved along the evolutionary chain and are highly specific regarding tissue and development stages expression [65]. Nowadays there are more than 2000 human miRNAs registered in the miRBase database (release 19, August 2012). MiRNAs are regulators of gene translation and subsequent expression and have been described as crucial in several cellular pathways, such as apoptosis, differentiation, proliferation and others (Figure 6) [65, 66]. MiRNAs constitute only $1 \%$ of human genome but are estimated to regulate the expression of $50 \%$ of human genes [65].

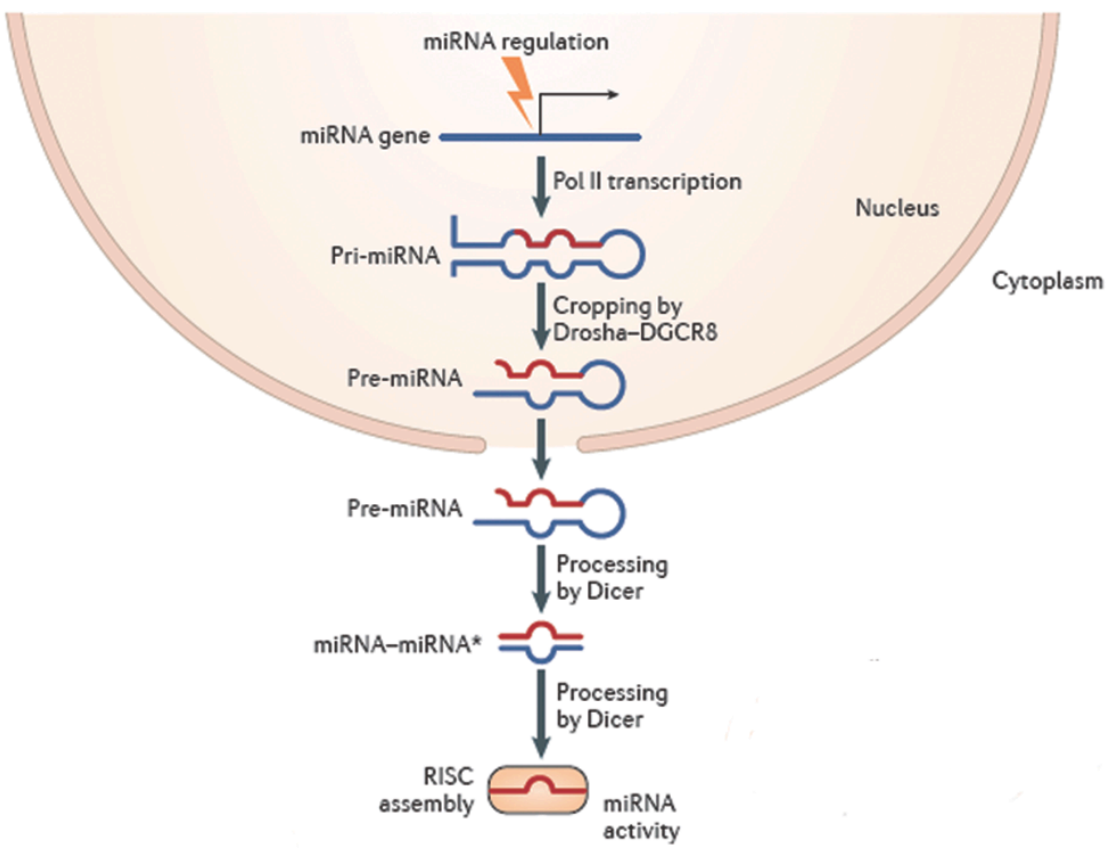

Figure 6. MicroRNAs biogenesis (adapted from [66]).

MicroRNAs pass trough a long maturation process that begins in the nucleus and ends in the cytoplasm (Figure 6). MiRNAs are firstly transcribed in the nucleus by RNA polymerase II resulting in long primary transcripts with multiple hairpin structures (pri-miRNAs) [67]. Then, the RNase III Drosha processes these molecules still in the nucleus by enzymatic cleavage resulting in a precursor-miRNA (pre-miRNA) of $\sim 70$ nucleotides [68]. Drosha is not alone in 
this maturation process and acts together with Di George Syndrome critical region gene 8 (DGCR8) to form the so-called "microprocessor complex" [69]. $D G C R 8$ is responsible to guide Drosha positioning in the pri-miRNA structure for cleavage [69]. However, some intronic miRNAs, mirtrons, are processed by the splicing machinery, skipping Drosha-mediated cleavage. This represents an alternative to the canonical mechanism [67, 68]. From this point on, canonical and alternative mechanisms merge following a common pathway. Pre-miRNAs are then specifically recognized by a nuclear export receptor, Exportin 5 (XPO5) [67]. Export occurs in a Ran-GTP dependent manner as pre-miRNAs are connected with Ran, a GTPase responsible for transporting RNA and proteins through the nuclear pore towards cytoplasm $[68,69]$. Once in the cytoplasm, pre-miRNAs undergo the final maturation process. The RNase III enzyme DICER 1 is responsible for converting pre-miRNAs to mature duplex miRNA [68]. Dicer binds to Transactivator RNA (tar)-binding protein (TRBP) to process pre-miRNAs and originate a short duplex miRNA/miRNA* [67]. This duplex contains a mature miRNA (guide strand) and a complementary strand, miRNA* (passenger strand) [68]. The mature miRNA is transferred to an Argonaute (Ago) protein, mediated by TRBP, and typically in a duplex the guide strand is the one with less pairing stability at the 5' end [69]. In fact, Dicer's helicase domain is responsible for sensor the thermodynamic stability of both strands and positions dsRNA to a correct orientation for right incorporation of the guide strand into the complex [69]. The complex of a mature miRNA and Ago proteins is designated as miRNA-containing RNA-induced silencing complex (RISC) [67].

\subsection{Modus operandi: how they exert their function?}

Once a miRNA is included in RISC it may regulate expression by guiding the catalytic complex to its target mRNA [70]. It is postulated that more than half of human genes $(\sim 50 \%)$ are regulated post-transcriptionally by miRNAs, showing their importance for a normal cell behavior $[67,71]$. In the last years more data emerged regarding how miRNAs interaction with their targets. Most studies report miRNAs as negative regulators of expression, although recent data have indicated an opposite role for this non-coding RNAs [72]. Herein, focus will be exclusively on the well-known role of expression repression. In mammals, miRNAs typically couple with their targets imperfectly requiring only perfect base pairing for nucleotides 2-8 of their sequence, the seed region [73]. Hence, a 
perfect matching miRNA-mRNA rarely occurs [67]. These two mechanisms result in different outcomes for the mRNA target, converging exclusively in translational inhibition. A total pairing conduces to site-specific cleavage, whereas, imperfect match leads to mRNA degradation [67]. Initially, miRNAs binding sites were exclusively located in the 3'-untranslated regions (UTRs) of target mRNAs [67, 70, 73]. Recently, 5'-UTR and open reading frames (ORF) were reported as containing target sequences for miRNAs function, increasing the complexity degree in miRNAs' research field (Figure 7) [67]. Remarkably, miRNAs can interact with ribonucleoproteins interposing in their RNA binding functions [74] and are also able to regulate gene expression, at transcriptional level, by direct binding to DNA [75-77]. Taking into account different rules for miRNA-mRNA interaction and moderate affinity of a miRNA and its target, it stands out that each miRNA have potential to regulate several different targets [67]. Therefore, its effect is a sum of each target inhibition [70]. Several reports demonstrated that a single gene might be target for several miRNAs, suggesting cooperation between them [67].

In sum, a single miRNA can regulate several mRNAs, and a single mRNA is target for different miRNAs. MiRNAs capacity of being regulators of multiple mRNAs places them on top of cellular pathways regulation, confirming the importance of their deregulation in diseases, such as cancer.

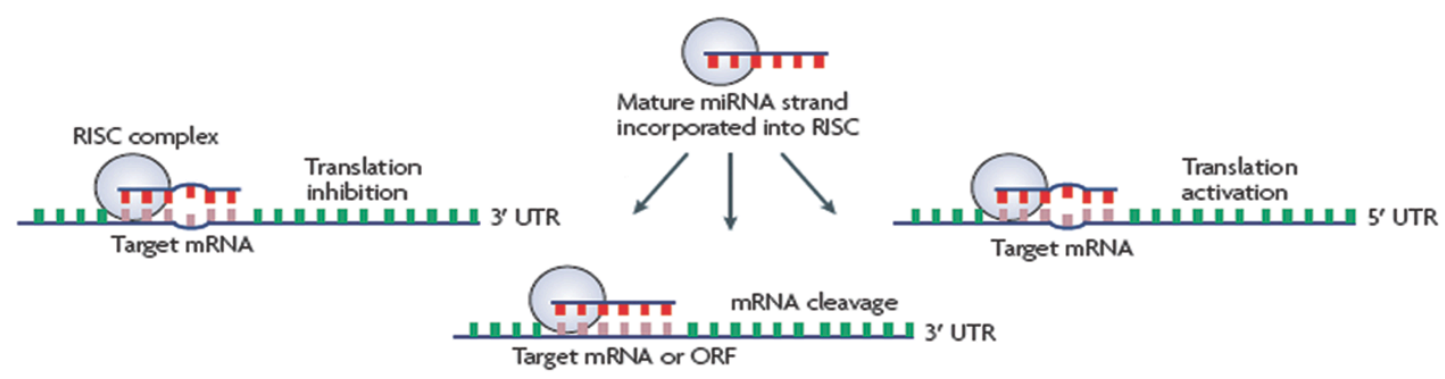

Figure 7. MicroRNAs mechanisms of action (adapted from [89]).

\subsection{Target prediction: down the microRNA river}

However, in accordance with the above-mentioned, prediction of miRNAmRNA interactions are rather complex due to different layers of potential relations [78]. In the last years, several algorithms were designed in order to find possible miRNA-mRNA interactions [78]. Those algorithms mostly differ in the use, or not, of conservation comparison, which generates different lists of targets [79]. More specifically: miRanda, PicTar, TargetScan and DIANA-microT follow the conservation criteria; PITA and rna22 have other features than conservation [78]. 
Nevertheless, there is no universal algorithm, and instead it has been proposed a workflow using some of the available algorithms [78]. The first step should be performed using a program that considers site conservation due to its higher precision and sensitivity. Then, researchers must use algorithms that contemplate other features. After selection of candidate target mRNAs the expression of both miRNA and targets must be evaluated in order to detect overlapping and/or inverse correlations. The last step should be a validation of targeting sites in the identified target mRNAs for each studied miRNA [78]. Therefore, numerous techniques have been developed or adapted in order to perform this last task. Nowadays, gene reporter assays [80], microarray analysis [81], proteome analysis [82], immunoprecipitation [83] among other techniques are used in miRNAs studies. Generally, these studies are performed after cell lines transfection of miRNA mimics (expression enhancers) or inhibitors (expression repressors), to verify which genes are then deregulated and what are the matching phenotypic effects $[84,85]$.

Nevertheless, there is still a lot to be unveiled regarding miRNA-mRNA interactions and specific target lists. Once this is achieved, it will give a wider perception on miRNAs role in cancer onset and progression, as well as in the underlying alterations.

\subsection{MicroRNAs deregulation in cancer: a warning sign}

Eleven years ago, Calin et al. published the first study connecting miRNAs to cancer, after finding miR-15a and miR-16-1 downregulated by deletion in B-cell chronic lymphocytic leukemia [86]. Since this study and following all the hype surrounding miRNAs and cancer research, several studies have been published regarding miRNAs involvement in tumorigenesis. In fact, both genetic and epigenetic mechanisms are involved in miRNAs deregulation contributing to its tumorigenic potential [68]. Globally, miRNAs have a reduced expression in cancer, but specific upregulation has also been reported [87]. The majority of miRNAs are in fragile locations, normally resulting in loss of its expression by chromosomal abnormalities [88]. However, miRNAs are deregulated by other factors, such as the disruption of enzymatic machinery involved in their maturation [68]. In fact, this is of extreme importance since it might affect all miRNAs within a disrupted cell. Concerning genetic alterations, mutations and single nucleotide polymorphisms (SNPs) have also their share for alter miRNAs 
expression [68]. A deregulation in miRNAs' expression may also be caused by modified activity of transcription factors at their promoters [68, 89]. MicroRNAs are also targeted by defects in the epigenetic machinery, which are perfectly described for tumor cells $[68,87,90]$. Indeed, about $20-40 \%$ of miRNAs are located close to $\mathrm{CpG}$ islands and aberrant patterns of methylation might also deregulate miRNAs expression in neoplasias [91]. Histone modifications have also been described as one of the players responsible for miRNAs aberrant expression in cancer [87]. Hereupon, all these alterations commonly present in neoplasias are now being described as deregulators of miRNAs normal state within a cell. As previously mentioned, miRNAs have multiple targets, and altered expression of a single miRNA may affect several cellular pathways.

Over the past years, with the intention to simplify nomenclature involving miRNAs and cancer, and considering their function, they have been classified as tumor-suppressors or oncogenes similarly to protein-coding genes [90]. This classification is not straightforward depending on tissue and target genes [92]. On one side, a miRNA with loss of function and with an oncogene as mRNA target is referred as a tumor-suppressor. On the opposite side, a miRNA with gain of function in a given tumor and with a tumor-suppressor mRNA as target is called as oncogene (Figure 8) [93].

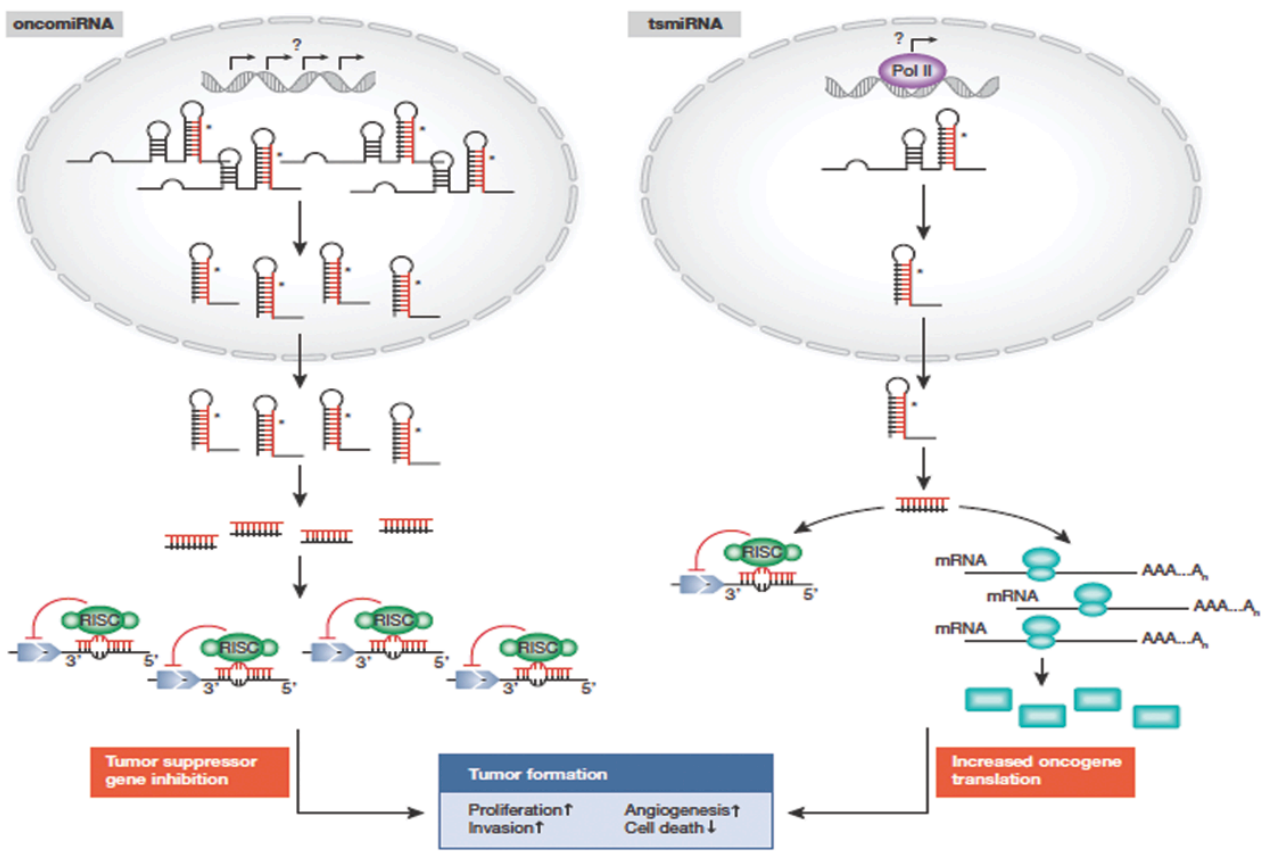

Figure 8. MicroRNAs dual role in cancer (adapted from [67]).

Despite increasing knowledge on miRNAs involvement in cancer, much is still to be found, especially regarding their role in tumorigenesis: which targets 
and pathways they control [67]. Nevertheless, miRNAs are emerging as promising biomarkers for early detection, prognosis and prediction of response to therapy $[94,95]$. MicroRNAs are also being investigated as future therapeutical target and some advances have been made with this issue on sight [96].

\subsection{MicroRNAs deregulation: a new layer on prostate cancer complexity}

Considering what was previously mentioned, microRNAs deregulation is a rather common event in cancer and prostate cancer is not an exception. In 2007, Porkka et al. published the first study concerning wide expression of miRNAs in PCa [97]. Since then, more than 100 studies have been published concerning not only global expression but also studying specific targets and involvement in therapy [98]. There has been an attempt to ascertain a specific profile of miRNAs expression for PCa, but it has not been possible due to controversial results [98, 99]. This issue reflects the trouble of defining a precise landscape for miRNAs in PCa, which may be explained by several reasons such as: technical issues, quality of starting material and study design [99]. However, studies generally reported a global downregulation of miRNAs [100]. Throughout the years, researchers found that miRNA expression is extremely dynamic and has an intimate relationship with PCa [101]. Differential expression will depend on prostate carcinogenesis phase, molecular pathway responsible for tumor onset, treatment exposure and androgen dependence state [98]. Following disclosure of miRNAs presence in several body fluids and due to their structure that protects them from RNase delaying their degradation, miRNAs are now seen as potential diagnosis, prognosis, and treatment-response biomarkers for PCa and finally as therapeutic targets $[102,103]$.

Nowadays, focus has been directed to uncover the relevance of miRNAs in prostate carcinogenesis by studying their targets. As for other tumors, miRNAs are involved in most of the cellular pathways that are deregulated in cancer, such as apoptosis, cell cycle, migration, invasion, proliferation and androgen signaling specific of PCa [99].

MiR-101 is frequently downregulated by deletion in PCa, particularly in metastatic disease. This miRNA targets the enhancer of zeste homologue 2 $(E Z H 2)$ supporting a tumor-suppressor activity, as its downregulation has been associated with EZH2 upregulation [104, 105]. MiR-101 expression decreases with prostate cancer progression and oppositely EZH2 activity tends to increase 
[104]. MiR-21 is commonly reported as deregulated in several types of neoplasms including PCa [106]. Several studies showed that miR-21 overexpression in PCa inhibit apoptosis in prostate cancer cell lines through targeting of programmed cell death 4 (PDCD4) and phosphatase and tensin homolog (PTEN) $[98,107]$ and is associated with increased invasion in LNCaP cell line [108]. More recently, miR21 was linked to androgen receptor signaling due to binding of androgen receptor $(A R)$ to its promoter [109]. Forced overexpression of miR-21 in mice resulted in growth arrest castration-mediated evasion, suggesting that this miRNA might be involved in AR-independent pathway in PCa $[105,110]$. One of the major concerns about PCa is the absence of a valid therapy for androgenindependent advanced cells, which evade apoptotic death. Therefore, miR-21 directed therapy might be a plausible alternative and valid therapy for these patients [101]. Contrarily, miR-15a and miR-16 are lost in PCa by deletion of its chromosomal location [1 111 ]. Several studies have been published regarding how these miRNAs are involved in PCa onset. It has been found that both miRNAs are essential on cell survival, proliferation and invasion [112], targeting several oncogenes such as B-cell CLL/lymphoma 2 (BCL2), myeloid cell leukemia sequence $1(M C L 1)$, cyclin D1 (CCND1) and wingless-type MMTV integration site family member 3A (WNT3A), showing their value as tumor-suppressor in PCa $[111,113]$.

Moreover, a common feature of PCa, especially of hormone refractory prostate tumors, is downregulation of miR-146a, a tumor suppressor in PCa [107]. This miRNA is able to control growth in PC-3 cell line through repression of Rho-associated protein kinase $1(R O C K 1)$ [114]. More recently, epidermal growth factor receptor (EGFR) was found as a target for miR-146a, and therefore underexpression of this miRNA contributes to initiation of ERK-mediated oncogenic pathway [1 15$]$.

MiR-205 is also a downregulated tumor-suppressor in PCa, which inhibits its capacity of prevent epithelial-to-mesenchymal transition (EMT), cell migration and invasion by repression of protein kinase Cepsilon [116]. Moreover, after restoring miR-205 expression in vitro some of the malignant phenotype was reversed [116]. Independent studies had reported miR-221/miR-222 as oncogenic and overexpressed in PCa [98]. These microRNAs are associated with development and metastases of PCa, and their main target is p27kip 1 causing its repression that eventually results in tumor growth [117]. In vitro overexpression of miR-221/222 in androgen dependent LNCaP cells induced androgen- 
independent growth [117]. Hence, these miRNAs seem to play an important role in development and maintenance of CRPC, although the specific mechanism is not fully understood [101]. However, similarly to miR-21, miR-221/222 are promising targets for therapy in advanced PCa.

MiR-331-3p is frequently downregulated in PCa, shutting down its tumorsuppressor function, once this miRNA is responsible for repressing erythroblastic leukemia viral oncogene homolog 2 (HER2) and $A R$ signaling [1 18]. Additionally, when this miRNA is overexpressed in vitro, it results in reduced HER2 expression and blockage of AR signaling [1 18 .

MiR-141 is frequently reported as overexpressed in PCa and is controlled by androgen pathway [119]. Furthermore, its overexpression in LNCaP cells resulted in an increase of cell proliferation, pointing to an oncogenic role behind PCa progression [1 19 ].

Expression levels of miR-449 were found to be lower in prostate tumors than in normal prostate tissues, and this miRNA has been described as a regulator of histone deacetylase 1 (HDAC1) [120], which is overexpressed in about $70 \%$ of prostate tumors [121]. Reactivation of miR-449 in prostate cancer cells led to growth arrest and apoptosis, supporting a tumor-suppressor role for this miRNA in prostate cancer [120]. As previously referred, transcription factors are also responsible for miRNAs' expression regulation. Interestingly, p53 loss in PCa conduces to repression of miR-34a [122], which by its turn targets silent information regulator 1 (SIRT1) [123]. Once SIRT1 is able to reduce p53 expression, this network may reduce apoptosis and promote resistance to paclitaxel therapy scheme [98]. When miR-34a expression is reconstituted in PC-3 cells, it results in a cell-cycle arrest and increased apoptosis levels [124]. MiR$200 \mathrm{~b}$ is another miRNA often reported as downregulated in PCa [105]. In vitro studies showed that upon its reconstitution in PCa cells, cell migration and invasion rates were reduced, and cell adhesion was repressed, therefore promoting cell detachment [125]. This phenomenon occurs by downregulation of its previously upregulated oncogenic targets zinc finger E-box binding homeobox 1 and 2 (ZEB1, ZEB2) and zinc finger protein SNAI1 (SNAIL) [125].

Ultimately, and after understanding specific roles in prostatic carcinogenesis pathway, the goal is to establish therapeutic alternatives for PCa by directed targeting a specific miRNA or a group of miRNAs. In fact, some miRNAs are already in preclinical studies and the number is rising [103]. 


\section{AIMS OF THE STUDY}

MicroRNAs are one of the most exciting and promising fields in cancer research. Yet, there is still a need for a better understanding of their involvement in PCa. Since these molecules regulate so many targets, being engaged with countless cellular pathways, it is crucial to ascertain the impact of their deregulation in a major neoplasm like PCa. Thereby the main goal of this Master Thesis is to determine the role of overexpressed microRNAs in prostate carcinogenesis.

More specifically, several tasks were established:

1. Identify miRNAs upregulated in PCa samples compared with morphologically normal prostate tissues (MNPT).

2. Validate miRNAs overexpressed in PCa in a larger set of PCa and MNPT samples.

3. Evaluate phenotypic impact of miRNAs' inhibition and/or induced expression in PCa cell lines.

4. Ascertain which pathways are deregulated in vitro by the miRNAs studied and validate them in tissue samples. 


\section{MATERIAL AND METHODS}

\section{Clinical Samples}

\subsection{Patients and Sample Collection}

In order to perform this study, samples of 85 prostate adenocarcinomas were prospectively collected from patients with clinically localized disease consecutively diagnosed and submitted to radical prostatectomy at the Portuguese Oncology Institute - Porto, Portugal from 2001 to 2006. As control samples, 15 morphologically normal prostate tissues (MNPT) were collected from peripheral zones of 15 prostates of bladder cancer patients submitted to cystoprostatectomy that did not harbor PCa. All specimens were immediately frozen after surgical procedure and stored at $-80^{\circ} \mathrm{C}$ for further analysis. After histological confirmation of tumor and normal tissue within a specimen, freshfrozen tissue fragments were trimmed to augment the yield of target cells (>70\%). Histological slides from formalin-fixed paraffin-embedded tissue fragments were also obtained from the same surgical specimens and assessed for Gleason grade and TNM stage. Relevant clinical data was collected from the clinical records These studies were approved by the institutional review board [Comissão de Ética para a Saúde-(IRB-CES-IPOFG-EPE 019/08)] of Portuguese Oncology Institute - Porto, Portugal.

\subsection{RNA extraction}

Total RNA was extracted of the clinical samples used (85 PCa and 15 MNPT) with PureLink ${ }^{\mathrm{TM}}$ RNA Mini Kit (Invitrogen, Carlsbad, CA, USA) according to manufacturer's recommendations. In short, $750 \mu \mathrm{L}$ of TRIzol ${ }^{\circledR}$ Reagent (Invitrogen, Carlsbad, CA, USA) were added to a tube containing a tissue sample. After that, a tissue homogenizing apparel was used in order to homogenize and $750 \mu \mathrm{L}$ of TRIzol ${ }^{\circledR}$ Reagent was again added. An incubation period of 10 minutes at room temperature preceded the addition of $300 \mu \mathrm{L}$ of chloroform (Merck, Darmstadt, Germany). This mixture was vortexed and incubated for 3 minutes at room temperature, and submitted to a centrifugation of 15 minutes at $12,000 \mathrm{~g}$ and $4^{\circ} \mathrm{C}$. After this, $600 \mu \mathrm{L}$ of the upper phase, containing RNA, were transferred to a new tube together with $600 \mu \mathrm{L}$ of $70 \%$ ethanol and tubes were strongly 
agitated. Next, $700 \mu \mathrm{L}$ of this mixture were relocated to a Spin Cartridge, previously placed in a collection tube. These components were then centrifuged at $12,000 \mathrm{~g}$ for 15 seconds at room temperature. Flow-through was subsequently discarded and remaining aqueous phase was transferred to the Spin Cartridge and was again centrifuged. Then, $700 \mu \mathrm{L}$ of Wash Buffer I were added and another centrifugation was performed. After this, Spin Cartridge was moved to a new collection tube and added $500 \mu \mathrm{L}$ of Wash Buffer II followed by another centrifugation. This step was repeated and finally a centrifugation of 1 minute was performed to assure maximum cleaning. Lastly, Spin Cartridge was placed in a new tube to collect RNA by elution with $50 \mu \mathrm{L}$ of RNase-free water, incubation for 3 minutes at room temperature and 2 minutes centrifugation at $12,000 \mathrm{~g}$. This step was then repeated culminating in a final volume of about $100 \mu \mathrm{L}$.

RNA concentrations and purity ratios were ascertained using a NanoDrop ND-1000 spectrophotometer (NanoDrop Technologies, Wilmington, DE, USA). RNA quality was verified by electrophoresis and RNA samples were stored at $80^{\circ} \mathrm{C}$.

\subsection{MicroRNAs cDNA synthesis}

CDNA synthesis was performed using miRCURY LNA ${ }^{\text {TM }}$ Universal RT microRNA PCR (Exiqon, Vedbaek, Denmark) following manufacturer's instructions. This kit offers two main advantages: first, provides template for all miRNAs by adding a poly-A tail to mature miRNA sequence that is recognized by a poly-T primer; second, an amplification step to generate higher quantities of miRNAs (Figure 9).

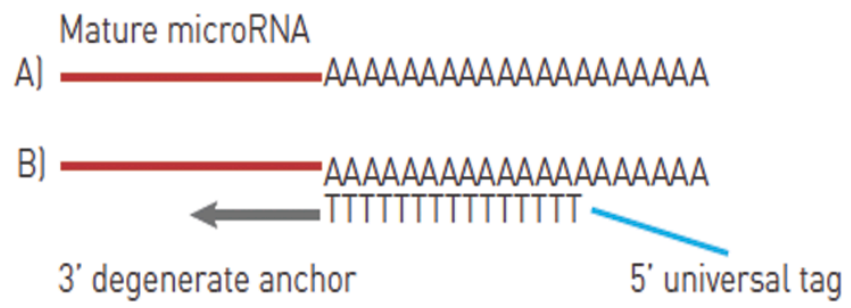

Figure 9. Specific microRNA cDNA synthesis (adapted from miRCURY LNA UNIVERSAL RT microRNA PCR provided by Exiqon).

Briefly, all RNA samples previously extracted were first adjusted to a $5 \mathrm{ng} / \mu \mathrm{L}$ concentration, using nuclease-free water (Exiqon). On ice, per each RNase-free PCR tube was added: $4 \mu \mathrm{L}$ of $5 x$ Reaction Buffer, $9 \mu \mathrm{L}$ nuclease-free 
water, $2 \mu \mathrm{L}$ of enzyme mix, $1 \mu \mathrm{L}$ of synthetic spike in, and $4 \mu \mathrm{L}$ of previously concentration-adjusted RNA. Tubes were then vortexed gently and reverse transcription was performed in a Veriti ${ }^{\circledR}$ Thermal Cycler (Applied Biosystems, Foster City, CA, USA). Protocol consisted in incubation for 60 minutes at $42^{\circ} \mathrm{C}$, followed by 5 minutes at $95^{\circ} \mathrm{C}$. Finally samples were stored at $-20^{\circ} \mathrm{C}$.

\subsection{MicroRNAs panel: global expression}

Global miRNAs' expression was evaluated, in 10 PCa and 4 MNPT using microRNA Ready-to-Use PCR Human Panel (Exiqon), which consists of two 384well plates accounting for 739 lyophilised primers of human miRNAs. In each well, it was added $0.05 \mu \mathrm{L}$ of cDNA previously synthesized, $5 \mu \mathrm{L}$ of $\mathrm{Sybr}^{\circledR}$ Green master mix (Exiqon) and $4.95 \mu \mathrm{L}$ of nuclease-free water (Exiqon). Reactions were performed in the LightCycler 480 instrument (Roche Diagnostics, Manheim, Germany) according to the following conditions: $95^{\circ} \mathrm{C}$ for 10 minutes and 45 cycles at $95^{\circ} \mathrm{C}$ for 10 seconds and $60^{\circ} \mathrm{C}$ for 1 minute. A melting curve analysis was also made according to manufacturer's suggestions to verify specificity and identity of amplification reaction. Each plate, besides containing miRNAs, also had 3 interplate calibrators, 2 water blanks, 3 empty wells and 6 reference genes (SNORD38B, U6, SNORD49A, miR-191, miR-423-5p, miR-103).

Data were analyzed using GenEX software (MultiD Analyses AB, Göteborg, Sweden). Difference in expression values for a single miRNA was calculated by the $2-\Delta \Delta c t$ method and converted to logarithmic scale. Due to high standard deviation results for reference genes between sample's groups (tumor and normal), median value of references were used for normalization. MiRNAs with fold change above 1.5 were classified as overexpressed in PCa compared to MNPT.

\subsection{MicroRNAs expression: individual assays}

Initially, cDNA samples of 80 PCa and 15 MNPT (75 and 11 independent from panel samples, respectively) were freshly diluted $80 \mathrm{x}$ in nuclease-free water (MP Biomedicals, LLC, Solon, OH, USA) in low-nucleic acid binding tubes, as recommended by manufacturer. Then, on ice, per each well of a 96 -well plate it was added: $5 \mu \mathrm{L}$ of $\mathrm{Sybr}^{\oplus}$ Green master mix (Exiqon), $1 \mu \mathrm{L}$ of miRNA specific primer mix (microRNA LNA ${ }^{\mathrm{TM}}$ PCR primer set, Exiqon), $0.2 \mu \mathrm{L}$ of ROX reference dye (Invitrogen) and $4 \mu \mathrm{L}$ of previously diluted cDNA. RT-qPCR protocol was 
carried out in triplicates for each sample on a 7500 Sequence Detection System (Applied Biosystems). Protocol consisted in a denaturation step at $95^{\circ} \mathrm{C}$ for 10 minutes, followed by 40 amplification cycles at $95^{\circ} \mathrm{C}$ for 10 seconds and $60^{\circ} \mathrm{C}$ for 1 minute (Figure 10). As previously referred a melting curve analysis was also performed in the end of the procedure according to instrument's manufacturer recommendations. Each plate also contained 2 negative template controls (only reaction $\mathrm{mix}$ ) and five serial dilutions (10x dilution factor) of cDNA from total human prostate RNA (Ambion, Invitrogen, Carlsbad, CA, USA) previously synthesized similarly to patient samples. These serial dilutions allowed generation of a standard curve for relative quantification and ascertain PCR efficiency.

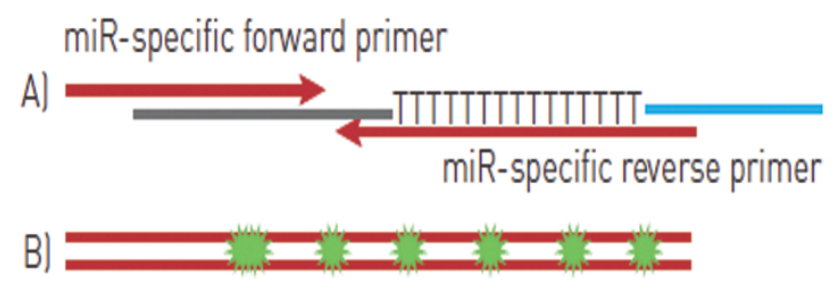

Figure 10. Amplification of microRNAs' cDNA (adapted from miRCURY LNA UNIVERSAL RT microRNA PCR provided by Exiqon).

Relative expression of miRNAs tested in each sample was obtained using the formula: relative expression = target gene mean quantity/reference gene mean quantity. This ratio was then multiplied by 1000 for easier tabulation. Reference gene used for normalization was miR-423-5p as this gene had the lowest coefficient of variation in the miRNAs global expression protocol, between samples and samples' groups. In Table 2 are present individual assays used and also their specific sequences.

Bear in mind that the same exact protocol was used to evaluate miRNAs expression in cell lines and ascertain expression after transfection with precursor and inhibitor molecules. 
Table 2. Specific target sequences for microRNAs tested.

\begin{tabular}{l|c}
\hline \multicolumn{1}{c|}{ GENE } & TARGET SEQUENCE \\
\hline hsa-miR-375 & 5'- UUUGUUCGUUCGGCUCGCGUGA -3' \\
\hline hsa-miR-32 & 5'- UAUUGCACAUUACUAAGUUGCA -3' \\
\hline hsa-miR-182 & 5'- UUUGGCAAUGGUAGAACUCACACU -3' \\
\hline hsa-miR-423-5p & 5'- UGAGGGGCAGAGAGCGAGACUUU -3' \\
\hline
\end{tabular}

\section{IN VITRO STUDIES}

\subsection{Cell Culture}

In this study, four PCa cell lines (LNCaP, 22Rv1, DU145, PC-3) and a normal prostate cell line (RWPE-1) were evaluated. Regarding cell lines representative of $\mathrm{PCa}$, they differ in some features of the adenocarcinoma; on one side, LNCaP and 22Rv1 are hormone-sensitive, on the other side DU145 and PC-3 are castration-resistant. RWPE-1 is a normal epithelial cell line originated from the peripheral zone of a histologically normal adult human prostate. LNCaP and PC-3 were kindly provided by Prof. Ragnhild A. Lothe from the Department of Cancer Prevention at The Institute for Cancer Research at Oslo, Norway; DU145 was kindly ceded by Prof. Fátima Baltazar from the Life and Health Sciences Research Institute at the University of Minho, Braga, Portugal; 22Rv1 was gently ceded by Prof. David Sidransky from The Johns Hopkins University School of Medicine, Baltimore, MD, USA; RWPE-1 was generously provided by Prof. Margarida Fardilha from University of Aveiro, Portugal.

All prostate cell lines were grown using the recommended medium and correspondent supplements (Table 3 ) and $1 \%$ of Penicillin-Streptomycin (P-S) (GIBCO, Invitrogen, Carlsbad, CA, USA). Cell culture flasks were kept at $37^{\circ} \mathrm{C}$ and $5 \% \mathrm{CO}_{2}$ at a humidifying chamber. Cell lines were subcultured using a dissociation reagent, TrypLE ${ }^{\mathrm{TM}}$ Express (GIBCO) to harvest them and obtain the wanted number of $75 \mathrm{~cm} 3$ cell culture flasks.

All cell lines were routinely tested by a specific multiplex PCR for contamination by Mycoplasma spp. 
Table 3. Culture media conditions for prostate cell lines.

\begin{tabular}{l|c|c}
\hline CELL LINE & GROWTH MEDIUM & SUPPLEMENTS \\
\hline RWPE-1 & K-SFM & $\begin{array}{c}\text { Bovine pituitary extract (BPE) } \\
\& \\
\text { Human recombinant epidermal growth } \\
\text { factor (EGF) }\end{array}$ \\
\hline PC-3 & F-12+RPMI-1640 & \\
\hline 22 Rv1 & RPMI-1640 & \multirow{2}{*}{ 10\% Fetal bovine serum (FBS) } \\
\hline DU145 & MEM & \\
\hline LNCaP & RPMI-1640 & \\
\hline
\end{tabular}

\subsection{MicroRNA Transfection}

To perform miR-375 transfection in prostate cell lines, PC-3, 22Rv1 and RWPE-1 were cultured in 96-well plates and 6-well plates at optimized different concentrations (Table 4). Cells were transfected with a Pre-miR ${ }^{\mathrm{TM}}$ miRNA Precursor (pre-miR-375, PM10327, Applied Biosystems) in PC-3 and RWPE-1, an Anti-miR ${ }^{\text {TM }}$ miRNA Inhibitor (anti-miR-375, AM10327, Applied Biosystems) in 22Rv1 and miRNA Negative Control (miR-NC, AM17010, Applied Biosystems) in all cell lines used.

Table 4. Number of cells plated for in vitro experiments for each cell line tested.

\begin{tabular}{c|c|c}
\hline \multirow{2}{*}{ CELL LINE } & \multicolumn{2}{|c}{ NUMBER OF CELLS PER WELL } \\
\cline { 2 - 3 } RWPE-1 & 6-well plate & 96-well plate \\
\hline PC-3 & 600,000 & 12,000 \\
\hline 22Rv1 & 200,000 & 4,000 \\
\hline
\end{tabular}


Briefly cells were cultured one day prior to transfection protocol to guarantee a 30-50\% confluence at time of transfection. Concentrations of precursor and inhibitor molecules were first optimized and defined as: precursor $(10 \mathrm{nM}$ and $50 \mathrm{nM})$ and inhibitor (25nM and 50nM). Negative controls (miR-NC) were always used at the highest concentration for both precursor and inhibitor experiments (50nM) to control cytotoxicity in miRNA-375 transfected cells. This control consists of molecules tested in human cells and shown as not producing effects on known miRNA function. Transfection was performed, as suggested by manufacturer, using Oligofectamine ${ }^{\mathrm{TM}}$ Reagent (Invitrogen), which favours an efficient and highly specific transfection into cells. Briefly, transfection molecules were diluted in Opti-Mem ${ }^{\circledR} 1 \times$ (GIBCO) and simultaneously, $0.85 \mu \mathrm{L}$ of Oligofectamine $^{\mathrm{TM}}$ was added to $2.15 \mu \mathrm{L}$ of Opti-Mem ${ }^{\circledR}$ (96-well) and $4.5 \mu \mathrm{L}$ of Oligofectamine ${ }^{\mathrm{TM}}$ was added to $10.5 \mu \mathrm{L}$ of Opti-Mem ${ }^{\circledR}$ (6-well), and incubated for 10 minutes mixing gently. Diluted transfection molecules were combined with diluted Oligofectamine ${ }^{\mathrm{TM}}$ and incubated for 20 minutes to form complexes. Then, $80 \mu \mathrm{L}$ of medium without serum and $20 \mu \mathrm{L}$ of complexes were added to each well with cell content in 96 -well plates. For 6 -well plates, $800 \mu \mathrm{L}$ of medium without serum and $200 \mu \mathrm{L}$ were added. Plates were then incubated in a humidified chamber at $37^{\circ} \mathrm{C}$ and $5 \% \mathrm{CO}_{2}$ for 4 hours, when $50 \mu \mathrm{L}$ and $500 \mu \mathrm{L}$ of medium with $30 \%$ fetal bovine serum (FBS) were added in 96-well and 6-well plates respectively. Biological triplicates were performed for each condition. Cells were then incubated for 72 hours for further phenotypic assays.

\subsection{Cell Viability Assay}

In order to evaluate the impact of in vitro transfection of miR-375 in prostate cell lines viability, MTT assay was performed. This method was developed in 1983 by Mosmann, and is based on the cleavage of yellow-colored, 3-(4,5-dimethylthiazol-2-yl)-2,5-diphenyltetrazolium-bromide, into a blue-colored formazan by the mitochondrial enzyme succinate-dehydrogenase [126, 127]. This technique is grounded on the fact that mitochondrial activity is constant in viable cells, allowing measuring differences between transfected and non-transfected cells $[128,129]$. The main advantage of this assay is that the reaction only occurs in living cells with functional mitochondria, standing as a direct measure of cell viability (Figure 11 ) [127]. 


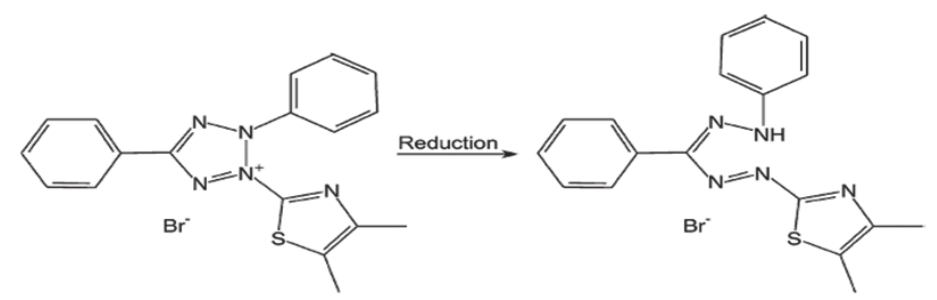

Figure 11. Chemical reduction of MTT, the principle of cell viability assay (adapted from [126]).

Prostate cells were seeded in 96-well plates (Sarstedt, Nümbrecht, Germany) at different concentrations (Table 4), depending on cell line, in $200 \mu \mathrm{L}$ of complete medium and incubated in a humidified chamber at $37^{\circ} \mathrm{C}$ and $5 \% \mathrm{CO}_{2}$. Cells were allowed to adhere and then viability assay was performed right before transfection (0 hours) and in subsequent days after transfection protocol (24, 48, 72 hours) at same time. Briefly, $20 \mu \mathrm{L}$ of MTT at $5 \mathrm{mg} / \mathrm{mL}$ (Sigma-Aldrich, Schnelldorf, Germany) diluted in $180 \mu \mathrm{L}$ of complete medium were added to each well and incubated in a humidified chamber $\left(37^{\circ} \mathrm{C}, 5 \% \mathrm{CO}_{2}\right)$ for 1 hour and a half. Then MTT solution was withdrawn and formazan crystals were dissolved in 100 $\mu \mathrm{L}$ DMSO (Sigma-Aldrich) and finally plates were shaken for 15 minutes for complete dissolution.

Absorbance levels were measured using a microplate reader (Fluostar Omega, BMG Labtech, Offenburg, Germany) at a wavelength of $540 \mathrm{~nm}$ with background deduction at $630 \mathrm{~nm}$. Nine blanks consisting of DMSO (SigmaAldrich) were included in each plate and optical density (OD) values were corrected using these blanks. Number of cells was obtained using the following formula: [(OD experiment $x$ Mean Number of cells at Day 0)/Mean OD at Day 0]. Three biological independent experiments were performed with methodological triplicates for each experiment.

\subsection{Apoptosis Assay}

Apoptosis evaluation was accomplished by using the APOPercentage ${ }^{\text {TM }}$ Apoptosis Assay (Biocolor Ltd., Belfast, Northern Ireland, UK). This assay uses a dye that is incorporated by cells undergoing apoptosis. Another important feature of the dye is that it does not stain necrotic cells as well as it stains initial stages of apoptosis process; therefore, it allows a better evaluation of apoptotic levels. This assay is based on phosphatidylserine transmembrane movements, which results in incorporation of the APOPercentage dye by cells in apoptosis (Figure 12). 


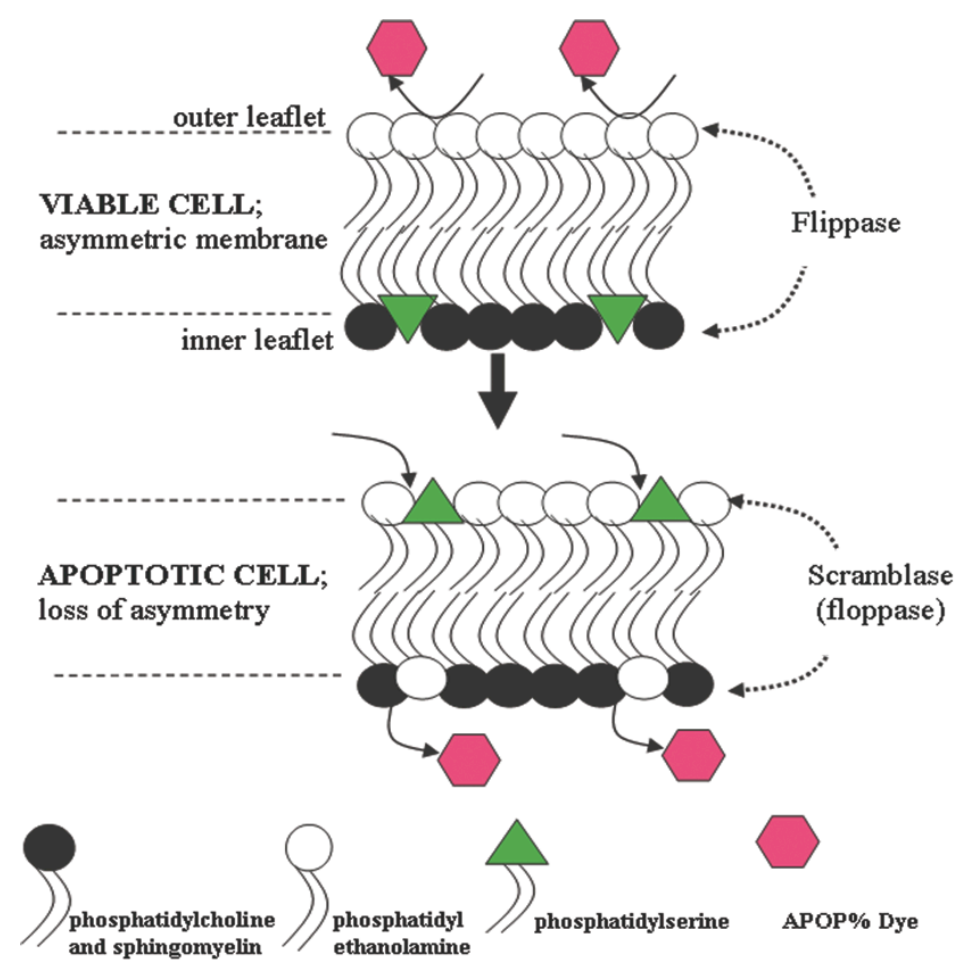

Figure 12. Apoptotis evaluation using APOPercentage Assay Kit (adapted from www.biocolor.co.uk).

Cells were grown in 96-well plates (Sarstedt) at different concentrations, depending on the cell line, in $200 \mu \mathrm{L}$ of complete medium and incubated in a humidified chamber at $37^{\circ} \mathrm{C}$ and $5 \% \mathrm{CO}_{2}$. One day after plating, cells were transfected and apoptosis assay was conduced 72 hours after transfection. In short, after medium removal $100 \mu \mathrm{L}$ of culture medium with $5 \%$ APOPercentage dye were added to each well and plates were then incubated at $37^{\circ} \mathrm{C}$ and $5 \% \mathrm{CO}_{2}$ for about 15 minutes. Then, medium was removed and $200 \mu \mathrm{L}$ of $1 \times$ phosphatebuffered saline (PBS) were added to wash the wells twice, to remove non-cell bound dye. After washing, $100 \mu \mathrm{L}$ of APOPercentage dye releasing reagent, which is an alkali solution responsible for disrupting the cell membrane and releasing of intracellular accumulated dye, were added to each well. Plates were then submitted to a 15 minutes shaking, and then each 3 wells of the same condition were joined in a single well. This last step results in three biological independent experiments with methodological triplicates for each experiment.

Absorbance levels were measured using a microplate reader (Fluostar Omega) at a wavelength of $550 \mathrm{~nm}$ with background deduction at $620 \mathrm{~nm}$. Hydrogen peroxide ( $5 \mathrm{mM}$ ) (Merck) was added to wells containing not transfected cells to serve as positive controls of apoptosis. Six blanks consisting of 
APOPercentage dye releasing agent were included in each plate and optical density (OD) values were blank corrected. So as to normalize the OD obtained for the apoptosis assay relatively to the cell number, OD of cell viability assay divided this OD. The results were expressed as the ratio of the OD of transfected cells to the miR-NC OD (set as 100\%).

\subsection{Invasion Assay}

To determine the impact of miR-375 transfection in PC-3 cell line invasion ability, it was ascertained using BD BioCoat ${ }^{\mathrm{TM}}$ Matrige $^{\mathrm{TM}}$ Invasion Chamber (BD Biosciences, San Jose, CA, USA) (Figure 13).

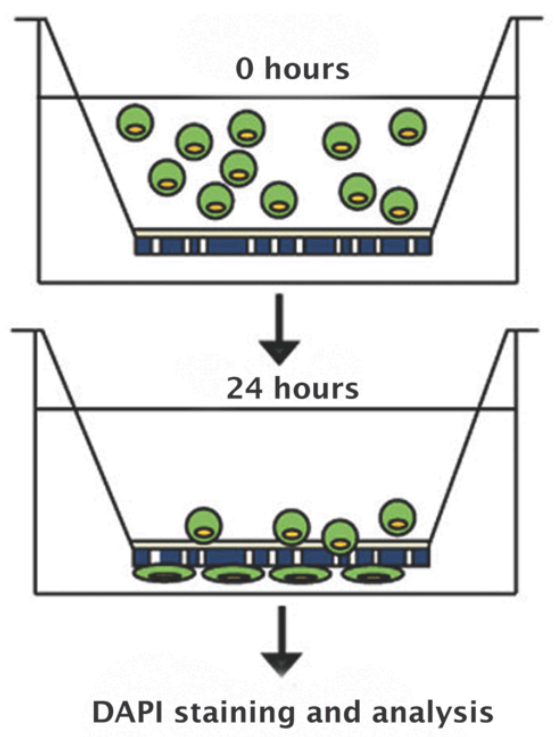

Figure 13. Principle behind BioCoat Matrigel Invasion Chamber and subsequent analysis of invasion (adapted from www.bmglabtech.com).

First step consisted of a rehydration procedure by adding $500 \mu \mathrm{L}$ of complete culture medium to the interior of the chambers and bottom of the wells. Then, plates were incubated at $37^{\circ} \mathrm{C}$ and $5 \% \mathrm{CO}_{2}$ for 2 hours, and afterwards medium was removed. PC-3 cells were seeded and transfected in 6well plates as above described and, 48 hours after transfection, cells were collected by trypsinization and per each chamber of invasion kit were seeded $2.5 \times 104$ cells in $500 \mu \mathrm{L}$ of free-serum medium. For all wells standing below chambers with PC-3 cells, it was added $750 \mu \mathrm{L}$ of medium with serum as a chemoattractant. Plates were then incubated for 24 hours in a humidified chamber at $37^{\circ} \mathrm{C}$ and $5 \% \mathrm{CO}_{2}$, according with manufacturer's instructions. After incubation period, medium was removed from both chambers and wells, and 
using cotton swabs, cells were gently removed from the upper side of the insert. Chambers were transferred to methanol at $4^{\circ} \mathrm{C}$, in order to fix cells in the lower side of the insert, invading cells, for 10 minutes at $4^{\circ} \mathrm{C}$. After this, chambers were washed with PBS, to clean the inserts and then were placed upside down to dry the inserts. Later, with the aid of a scalpel, inserts were cut in its inside portion to promote the least damage possible to the membrane and transferred to a slide. This membrane was then stained with VECTASHIELD ${ }^{\circledR}$ Mounting Media containing DAPI (Vector Laboratories, Inc., Burlingame, CA, USA) and finally invading cells were counted using a fluorescence microscope. Two independent experiments were performed for each condition with methodological triplicates.

\subsection{RNA extraction}

Total RNA from cell lines was extracted by TRIzo| ${ }^{\circledR}$ Reagent (Invitrogen) as recommended by manufacturer. Cells were cultured and transfected in 6-well plates and after collecting cell's pellets at 72 hours of transfection protocol, these were defrosted on ice and ressuspended in $1 \mathrm{~mL}$ of TRIzol ${ }^{\circledR}$ Reagent with the help of a $0.9 \mathrm{~mm}$ needle to homogenize. Then, samples were incubated for 5 minutes at room temperature followed by addition of $200 \mu \mathrm{L}$ of chloroform (Merck). After that, samples were briefly vortexed for 15 seconds and incubated for 3 minutes at room temperature. Tubes were then centrifuged at $11,900 \mathrm{~g}$ for 15 minutes at $4^{\circ} \mathrm{C}$. Then, the upper phase containing RNA was transferred to a new tube RNase-free and $500 \mu \mathrm{L}$ of $100 \%$ isopropanol were added, and then tubes were shaken by inversion. To RNA precipitation occur, samples were incubated for 10 minutes at room temperature followed by centrifugation for 10 minutes at $11,900 \mathrm{~g}$ at $4^{\circ} \mathrm{C}$. After supernatant removal, RNA pellets were washed with $1 \mathrm{~mL}$ of $75 \%$ ethanol and vortexed, being later centrifuged at $8,600 \mathrm{~g}$ for 5 minutes at $4^{\circ} \mathrm{C}$. This step was executed two times for a correct pellet washing. Finally, supernatant was rejected and RNA pellets were let to air dry for 15 to 20 minutes. Then, pellets were eluted with $40 \mu \mathrm{L}$ of RNA storage solution (1 mM Sodium Citrate, $\mathrm{pH}$ 6.4) (Ambion). RNA concentrations and purity ratios were determined using a NanoDrop ND-1000 spectrophotometer (NanoDrop Technologies). RNA quality was verified by electrophoresis and RNA samples were stored at $-80^{\circ} \mathrm{C}$. 


\subsection{Protein extraction}

Cell lines were grown in 6-well plates and transfected as previously stated. Protein extraction from cell lines was made using the Radio Immuno Precipitation Assay (RIPA) (Santa Cruz Biotechnology Inc., Santa Cruz, CA, USA). This protocol was carried out 72 hours after transfection experiment. Briefly, growth medium was withdrawn and cells were then washed with 1x PBS. After that procedure, 40 $\mu \mathrm{L}$ of RIPA buffer (10 $\mu \mathrm{L}$ of PMSF solution, $10 \mu \mathrm{L}$ of sodium orthovanadate solution and $20 \mu \mathrm{L}$ of protease inhibitor cocktail solution per $\mathrm{mL}$ of $1 \times$ RIPA lysis buffer) were added, and then cells were scrapped to promote lysis and removal. Cell lysate was transferred to a $1.5 \mathrm{~mL}$ tube and placed on ice for 15 minutes with periodic hand shaking. Samples were, then, centrifuged for 30 minutes at $18,000 \mathrm{~g}$ at $4^{\circ} \mathrm{C}$, and supernatant was collected to a new tube.

Protein concentration was ascertained by the Pierce BCA Protein Assay Kit (Thermo Scientific Inc., Bremen, Germany). This assay is a detergent-compatible formulation based on bicinchoninic acid (BCA) used for the colorimetric detection and quantitation of total protein. Protein concentrations were calculated using standards of bovine serum albumin (BSA) as references. Serial dilutions were prepared from this protein and measured together with cell lines samples. Briefly, $25 \mu \mathrm{L}$ of each standard or sample and $200 \mu \mathrm{L}$ of working reagent (50:1, Reagent $\mathrm{A}: \mathrm{B})$ were added to a $1.5 \mathrm{~mL}$-tube and then incubated at $37^{\circ} \mathrm{C}$ for 30 minutes. Tubes content were then relocated to a 96-well plate (Ratiolab, Dreieich, Germany) and absorbance levels were measured at $562 \mathrm{~nm}$ on a microplate reader (Fluostar Omega). Proteins were stored and kept at $-20^{\circ} \mathrm{C}$.

\section{TARGETS' EXPLOITATION}

\section{1. cDNA synthesis}

Total RNA extracted from PC-3 (miR-NC and pre-miR-375 at 50nM) and $22 \mathrm{Rv} 1$ (miR-NC and anti-miR-375 at 25nM) transfected cells were defrosted on ice and cDNA synthesis was achieved using Transcriptor High Fidelity cDNA Synthesis Kit (Roche Diagnostics), according to instructions by manufacturer. In short, a total of $500 \mathrm{ng}$ for each sample was transferred to a new sterile PCR-tube. Then, to each tube $2 \mu \mathrm{L}$ of Random Hexamer Primer and water to a final volume of 11.4 $\mu \mathrm{L}$ were added. This mix was denatured at $65^{\circ} \mathrm{C}$ for 10 minutes and immediately cooled on ice. After this, $4 \mu \mathrm{L}$ of $5 x$ Transcriptor High Fidelity Reverse 
Transcriptase Reaction Buffer, $0.5 \mu \mathrm{L}$ of Protector RNase Inhibitor, $2 \mu \mathrm{L}$ of Deoxynucleotide Mix, $1 \mu \mathrm{L}$ of Dithiothreitol (DTT) and 1.1 $\mu \mathrm{L}$ of Transcriptor High Fidelity Reverse Transcriptase were added to each tube totaling $20 \mu \mathrm{L}$. Samples were posteriorly incubated for 10 minutes at $29^{\circ} \mathrm{C}$ and 60 minutes at $48^{\circ} \mathrm{C}$, followed by enzyme inactivation for 5 minutes at $85^{\circ} \mathrm{C}$. In the end, samples were stored at $-20^{\circ} \mathrm{C}$.

\subsection{Custom expression panel}

A 384-well custom array panel (Roche Diagnostics) was designed containing 61 genes involved in cell cycle, apoptosis, DNA repair, mTOR, MAPK/ERK and AR pathways. Briefly, per each well was added $5 \mu \mathrm{L}$ of $2 x$ LighCycler $^{\circledast} 480$ Probes Master (Roche Diagnostics), 5ng of cDNA sample and water until $10 \mu \mathrm{L}$ of mix was reached. Each plate was then centrifuged for 2 minutes at $1,500 \mathrm{~g}$ and finally expression levels were determined using a LighCycler $^{\circledR} 480$ instrument (Roche Diagnostics). PCR program consisted of a preincubation cycle at $95^{\circ} \mathrm{C}$ for 10 minutes, 45 cycles of $95^{\circ} \mathrm{C}$ for 10 seconds, $60^{\circ} \mathrm{C}$ for 30 seconds and $72^{\circ} \mathrm{C}$ for 1 second, ending with a cooling $40^{\circ} \mathrm{C}$ for 30 seconds cycle. In order to normalize results, for each plate were also included endogenous controls Beta-D-Glucuronidase (GUS $\beta$ ), transferrin receptor (TFRC) and $18 \mathrm{~s}$ as reference genes.

Three biological independent replicates were run for all conditions previously referred. Comparative $\mathrm{Ct}$ was used to calculate fold-difference in gene expression between groups [130]. After obtaining logarithmic values, genes simultaneously upregulated in 22Rv1 and downregulated in PC-3 transfected cells were selected to posterior validation in clinical samples.

\subsection{Gene Ontology Enrichment}

In order to ascertain which biological processes are regulated by miR-375, a Gene Ontology Enrichment (GOE) analysis was performed by an experienced bioinformatics. Briefly, AmiGO database was used to obtain important information regarding genes present in custom array and their specific involvement in cellular pathways [131]. After data collection, a statistical analysis using the $\mathrm{R}$ program was performed based on a hypergeometric distribution (probability of $\mathrm{k}$ successes in $\mathrm{n}$ draws without replacement in a finite population of size $N$ containing $K$ successes) [132] followed by a Fisher's exact test. False 
discovery rate (FDR) was calculated in the end as the proportion of hypotheses thought to be significant that are not significant [132]. P-value was set at 0.05 for multiple testing.

\section{TARGETS' VALIDATION}

\section{1. cDNA synthesis: Whole Transcriptome Amplification}

In order to assure a maximum amplification and presence of total RNA within a sample after cDNA synthesis, it was used the TransPlex ${ }^{\circledR}$ Whole Transcriptome Amplification (WTA) Kit (Sigma-Aldrich). This kit involves, first a reverse transcription of RNA with universal non-self-complimentary primers and second, an amplification step with universal primers to produce WTA product. In this way, RNA from the same $80 \mathrm{PCa}$ and 15 MNPT samples used in individual miRNA assays were subjected to this synthesis. Briefly, $300 \mathrm{ng}$ of RNA were placed in a sterile PCR-tube together with $2.5 \mu \mathrm{L}$ of WTA Library Synthesis Buffer, $2.5 \mu \mathrm{L}$ of WTA Library Stabilization Solution and Nuclease-free water for a total volume of $24 \mu \mathrm{L}$. Samples were then incubated at $70^{\circ} \mathrm{C}$ for 5 minutes followed by immediately cooling on ice. Afterwards, $1 \mu \mathrm{L}$ of WTA Library Synthesis Enzyme was added to each tube, and samples were incubated in a Veriti ${ }^{\circledR}$ Thermal Cycler (Applied Biosystems) for 15 minutes at $24^{\circ} \mathrm{C}, 2$ hours at $42^{\circ} \mathrm{C}$ and 5 minutes at $95^{\circ} \mathrm{C}$. Reactions, when ready, were promptly placed on ice. Each sample after this process, was divided in 5 individual aliquots and for each was added $70 \mu \mathrm{L}$ of WTA Amplification Mix (60 $\mu \mathrm{L}$ of water, $7.5 \mu \mathrm{L}$ of WTA Amplification Master Mix, $1.5 \mu \mathrm{L}$ of dNTP Mix and $1 \mu \mathrm{L}$ of antibody inactivated hot-start Taq DNA Polymerase). Tubes were again placed in the thermal cycler for 3 minutes at $95^{\circ} \mathrm{C}$ and 17 cycles at $94^{\circ} \mathrm{C}$ for 20 seconds and $65^{\circ} \mathrm{C}$ for 5 minutes.

These products were then purified using the QIAquick ${ }^{\circledR}$ PCR Purification Kit (QIAGEN, Hilden, Germany) according to instructions. In short, in a QIAquick spin column previously placed in a $2 \mathrm{~mL}$ collection tube, samples were mixed with $350 \mu \mathrm{L}$ of Buffer PB and centrifuged at 18,000g for 60 seconds. Flow-trough was then discarded and $750 \mu \mathrm{L}$ of Buffer PE were added to each column and again centrifuged for 60 seconds at $18,000 \mathrm{~g}$. Centrifugation was repeated to assure maximum cleaning and then columns were placed in a sterile $1.5 \mathrm{~mL}$ tube. To elute cDNA, $40 \mu \mathrm{L}$ of nuclease free-water (Sigma-Aldrich) were added to the 
center of each column, and after incubation for 1 minute at room temperature, tubes were centrifuged at $18,000 \mathrm{~g}$ for 1 minute.

In the end, samples were diluted $5 x$ prior to RT-qPCR use and stored at $20^{\circ} \mathrm{C}$. Stock tubes were stored at $-80^{\circ} \mathrm{C}$.

\subsection{Expression Assays}

Genes identified as putative targets of miRNA-375 were quantified and validated by RT-qPCR. Validation was performed using expression assays specific for the targets as shown in Table 5. Reactions were carried out in 96-well plates using a 7500 Sequence Detection System (Applied Biosystems). Briefly, per each well, $10 \mu \mathrm{L}$ TaqMan ${ }^{\circledR}$ Universal PCR Master Mix (Applied Biosystems), $7 \mu \mathrm{L}$ of nuclease-free water (Sigma-Aldrich), $1 \mu \mathrm{L}$ of TaqMan ${ }^{\circledR}$ Gene Expression Assay and $2 \mu \mathrm{L}$ of previously synthetized cDNA were added. PCR program consisted of $50^{\circ} \mathrm{C}$ for 2 minutes, $95^{\circ} \mathrm{C}$ for 10 minutes and 40 cycles at $95^{\circ} \mathrm{C}$ for 15 seconds and $60^{\circ} \mathrm{C}$ for 1 minute, as recommended by manufacturer. All samples were run in triplicate and two negative template controls were included in each plate. Total human prostate RNA (Ambion) underwent same cDNA synthesis and was used to dilute in a five serial dilutions (10x dilution factor). These serial dilutions allowed generation of a standard curve for relative quantification and ascertain PCR efficiency.

GUS $\beta$, a housekeeping gene, was used as a reference gene to normalize results obtained for target genes. Relative expression of targets tested in each sample was obtained using the following formula: relative expression $=$ (target gene mean quantity/GUS $\beta$ mean quantity). This ratio was then multiplied by 1000 for easier tabulation.

Table 5. Gene expression assays.

\begin{tabular}{l|c}
\hline \multicolumn{1}{c|}{ GENE } & TAQMAN $^{\circledR}$ GENE EXPRESSION ASSAY \\
\hline$R B 1$ & Hs01078066_m1 \\
\hline CDKN1A (p21) & Hs00355782_m1 \\
\hline CCND2 (Cyclin D2) & Hs00153380_m1 \\
\hline CDK2 & Hs01548894_m1 \\
\hline
\end{tabular}




\section{Statistical Analysis}

In this work, non-parametric tests were used to ascertain statistical significance for comparisons made. Kruskal-Wallis test (KW) was used for comparisons between multiple groups (more than 2) and Mann-Whitney $U$ test (MW) was used in pairwise comparisons. These tests were used both in clinical samples and in vitro studies.

P-values were considered statistically significant when inferior to 0.05 for comparisons between two groups. When comparing multiple groups, Bonferroni correction was applied in subsequent paired comparisons, dividing P-value by number of comparisons performed.

Statistical analyses were performed using SPSS software for Mac, version 20.0 (IBM-SPSS Inc., Chicago, IL, USA). Graphs were built using GraphPad Prism 5.0 software for Mac (GraphPad Software Inc., La Jolla, CA, USA). 


\section{RESULTS}

\section{GLOBAL MIRNAS OVEREXPRESSION IN PCA TISSUES}

In order to obtain a list of miRNAs overexpressed in PCa compared with MNPT, we used a commercial platform containing 739 mature human miRNAs in 10 PCa and 4 MNPT. Data was analyzed using appropriate software and, as expected from literature, a higher percentage of miRNAs was found to be downregulated. Then, miRNAs with fold variation values higher than 1.5 were selected, resulting in a panel comprising 17 miRNAs (Table 6).

Table 6. Overexpressed miRNAs in microarray analysis. Chromosome location for miRNAs selected for further studies.

\begin{tabular}{l|c|c}
\hline \multicolumn{1}{c|}{ MICRORNA } & $\begin{array}{c}\text { FOLD VARIATION } \\
\text { (TUMOR VS. MNPT) }\end{array}$ & CHROMOSOME LOCATION \\
\hline miR-449a\# & 3.92 & \\
\hline miR-32 & 3.49 & $9 q 31.3$ \\
\hline miR-548c-5p\& & 2.71 & \\
\hline miR-562\& & 2.56 & \\
\hline miR-103-as\& & 2.53 & \\
\hline miR-512-3p & 2.41 & \\
\hline miR-200c*\& & 2.33 & \\
\hline miR-147b & 2.24 & \\
\hline miR-770-5p & 2.09 & \\
\hline miR-518c*\& & 2.00 & \\
\hline miR-517b & 1.88 & \\
\hline miR-182 & 1.79 & \\
\hline miR-615-3p & 1.70 & \\
\hline miR-496 & 1.59 & \\
\hline miR-1200\& & 1.58 & \\
\hline miR-375 & 1.54 & \\
\hline miR-551a & 1.53 & \\
\hline
\end{tabular}

\# Already studied in other work by our research group.

\& Primers did not work.

\section{VALIDATION OF OVEREXPRESSED MIRNAS}

We decided to validate miRNAs previously referred in literature corresponding to large-scale microarrays in PCa, but still not validated. We chose miR-32, miR-1 82 and miR-375 to validate, as a first approach, in a larger number of samples of PCa and MNPT by quantitative RT-PCR. We verified that miR-32 
expression levels were not statistically different between groups, whereas miR182 and miR-375 were significantly overexpressed in PCa samples $(p<0.001$ and $\mathrm{p}=0.022$ respectively) (Figure 14 ).
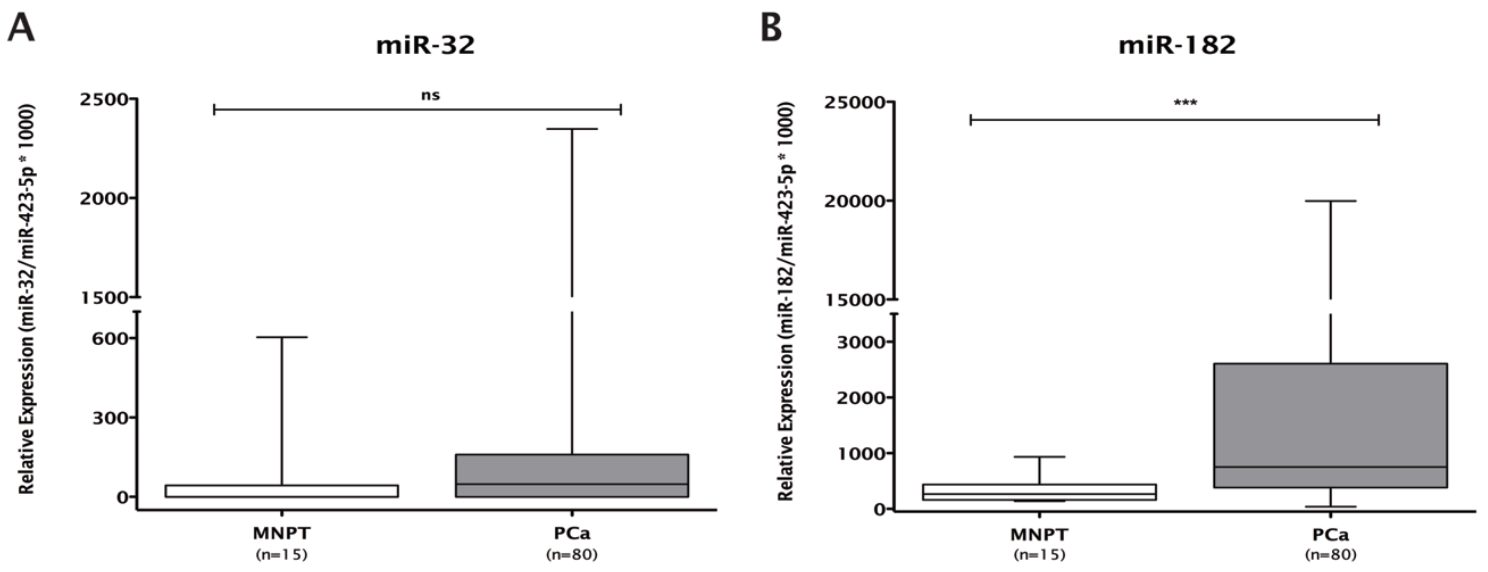

C

$\operatorname{miR}-375$

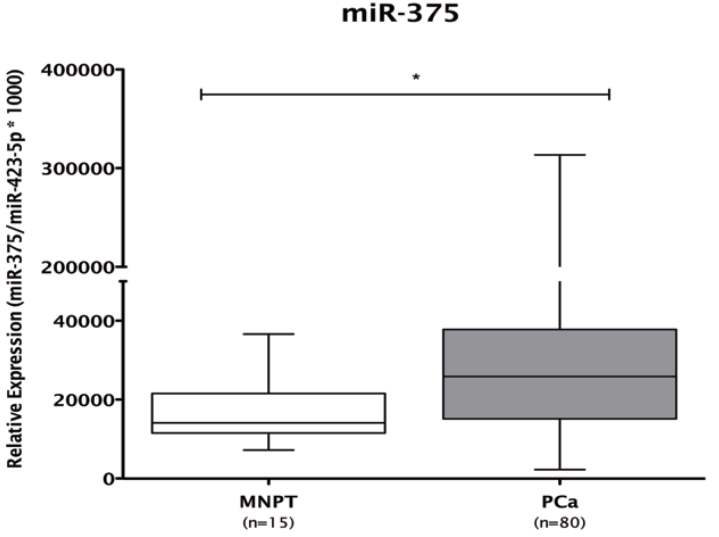

Figure 14. Expression levels of miRNAs (A) miR-32, (B) miR-182 and (C) miR-375 after validation $(* * * 0<0.001 ; * * \mathrm{p}<0.01 ; * \mathrm{p}<0.05$; ns - non-significant).

\section{ASSOCIATION BETWEEN GENES' EXPRESSION AND CLINICOPATHOLOGICAL FEATURES}

Clinical and pathological characteristics of patients included in this study are shown in Table 7.

Regarding age, PCa and MNPT groups did not significantly differ statistically. Expression levels of genes tested (miR-32, miR-182, miR-375, cyclin D2- CCND2, cyclin-dependent kinase 2- CDK2, retinoblastoma 1-RB1 and p21CDKNIA) and clinicopathological data were compared but statistical analysis did not disclose any association. 
Table 7. Clinical and pathological data of patients included in this study.

\begin{tabular}{|c|c|c|}
\hline ClinicopatholoGical DATA & $\begin{array}{l}\text { TUMORS } \\
(\mathrm{N}=80)\end{array}$ & $\begin{array}{c}\text { MNPT } \\
(N=15)\end{array}$ \\
\hline Age (yrs), median (range) & $65(49-74)$ & $64(45-80)$ \\
\hline PSA (ng/mL), median (range) & $\begin{array}{c}8.00 \\
(2.66-20.00)\end{array}$ & n.a. \\
\hline \multicolumn{3}{|c|}{ PATHOLOGICAL STAGE, N (\%) } \\
\hline pT2 & $49(61.3 \%)$ & n.a. \\
\hline pT3a & $24(30.0 \%)$ & n.a. \\
\hline pT3b & $7(8.7 \%)$ & n.a. \\
\hline \multicolumn{3}{|c|}{ GLEASON SCORE N (\%) } \\
\hline$<7$ & $25(31.3 \%)$ & n.a. \\
\hline$=7$ & $47(58.7 \%)$ & n.a. \\
\hline$>7$ & $8(10.0 \%)$ & n.a. \\
\hline
\end{tabular}

n.a., not applicable

\section{MIR-375 EXPRESSION IN PROSTATE CELL LINES}

In order to obtain an expression profile for miR-375 in prostate cell lines, we performed RT-qPCR in 4 PCa cell lines (PC-3, DU145, LNCaP, 22Rv1) and 1 normal prostate cell line (RWPE-1) (Figure 15). As expected from tissue samples, PCa cell lines displayed higher values for miR-375 expression than RWPE-1 normal cell line. Following this result, we decided to choose $22 \mathrm{Rv} 1$ as the most overexpressing PCa cell line, PC-3 as the least overexpressing of PCa cell lines and RWPE-1 as a normal prostate cell line, for further phenotypic studies.

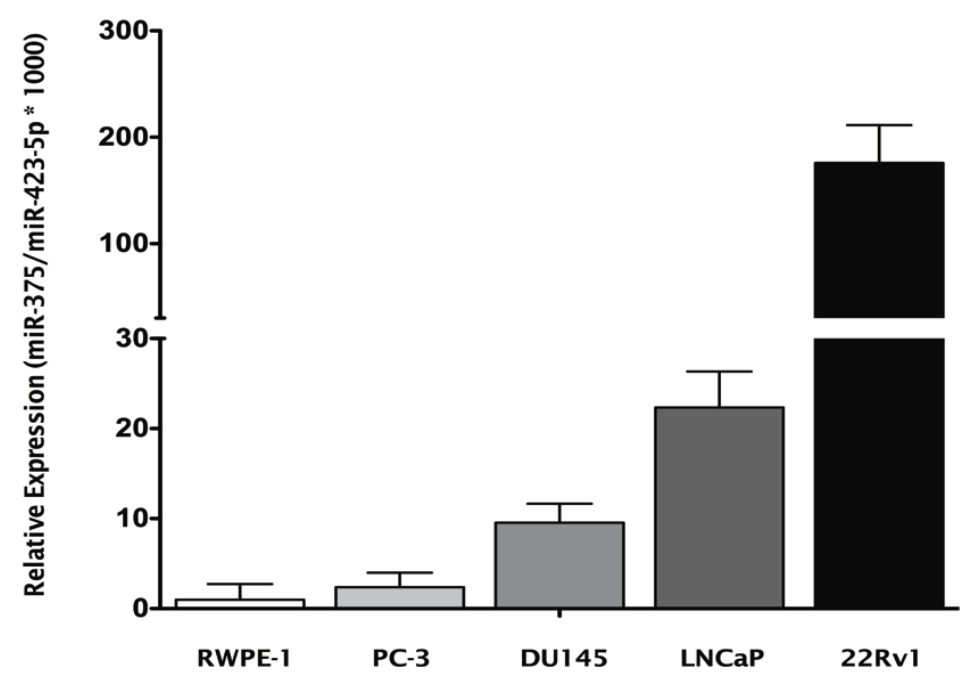

Figure 15. MiR-375 expression levels in prostate cell lines. Results are displayed after normalization to RWPE-1. 


\section{FORCED EXPRESSION OF MIR-375 IN A NORMAL PROSTATE CELL LINE, RWPE-1, DOES NOT ALTER PROSTATE PHENOTYPE}

Using two different concentrations for precursor molecules, $10 \mathrm{nM}$ and 50nM, we were able to induce miR-375's expression 4,000 and 7,000 times higher when compared with miR-NC transfected cells, respectively (Figure 16- A). However, induction of miR-375 in RWPE-1 did not alter significantly cell viability (Figure 16-B) or apoptosis (Figure 16-C) comparing with miR-NC cells.
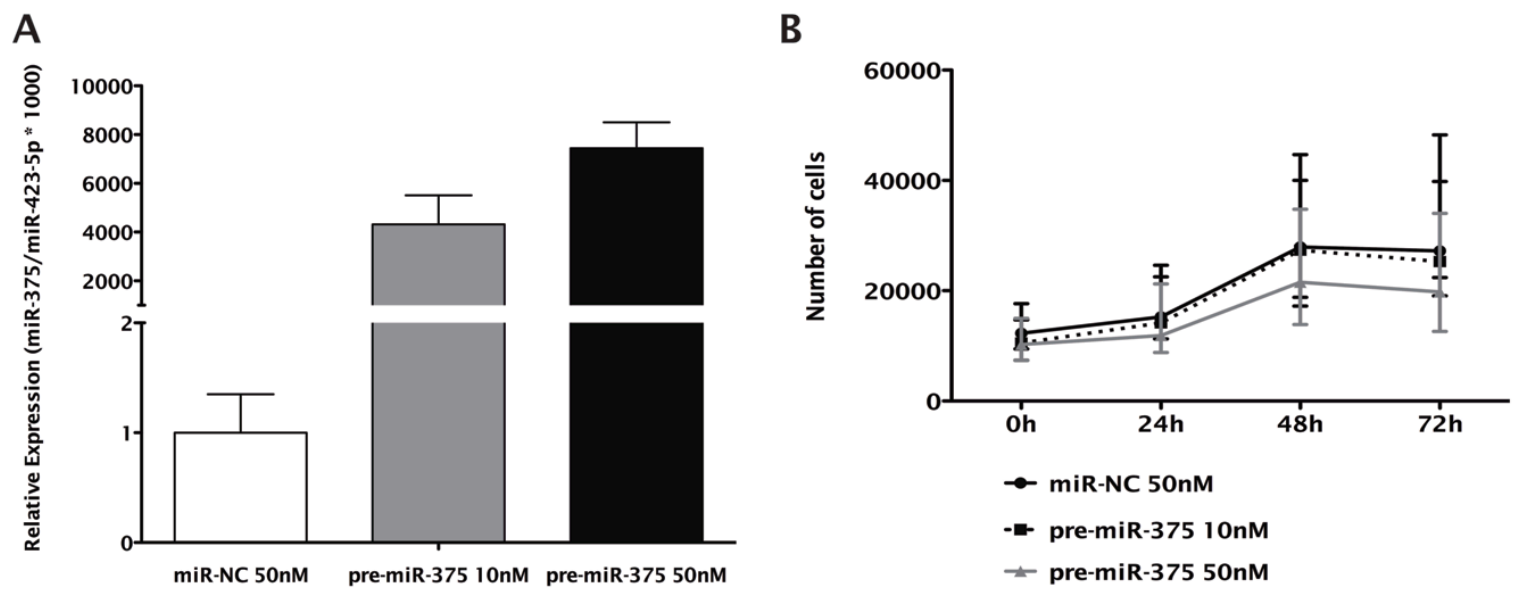

C

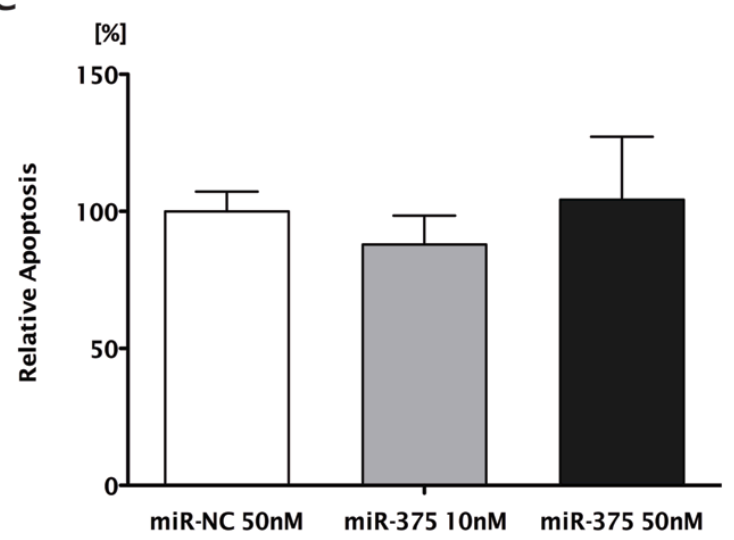

Figure 16. Forced expression of miR-375 in RWPE-1. (A) Relative expression of miR-375 (normalized to miR-NC), (B) Number of viable cells and (C) Relative apoptosis levels (normalized to miR-NC). (B,C) Data shown as the median and range of three independent experiments performed in triplicate.

\section{OVEREXPRESSION OF MIR-375 IN PC-3: EFFECT ON VIABILITY, APOPTOSIS AND INVASION ABILITY}

To assess the cellular phenotypic effect of miR-375 overexpression, we overexpressed this miRNA in PC-3 cell line, which normally displays low levels of this specific miRNA, as earlier demonstrated (Figure 15). Values of expression were measured 72 hours after transfection by RT-qPCR. PC-3 cells transfected 
with $10 \mathrm{nM}$ and 50nM of pre-miR-375 showed a 40,000 times and 56,000 times increase of expression compared to miR-NC (Figure 17- A). The 10nM pre-miR375 transfection only induced a cell viability reduction of $34.4 \%$ at 72 hours $(p=0.004)$. Regarding transfection with $50 \mathrm{nM}$ precursor molecules, cell viability was significantly reduced at 48 hours $(39 \%, p=0.007)$ and 72 hours $(60.5 \%$, $\mathrm{p}<0.001)$. Results were compared with miR-NC cells and are displayed in Figure 17- B.

Moreover, 72 hours after transfection, apoptosis levels were statistically increased for both concentrations (Figure 17- C). Indeed, for $10 \mathrm{nM}$ a $56 \%$ increase $(p=0.007)$ in apoptosis was found and a more impressive effect was observed for $50 \mathrm{nM}$, which caused a 3 times augment $(\mathrm{p}<0.001)$ compared to miR-NC transfected cells.
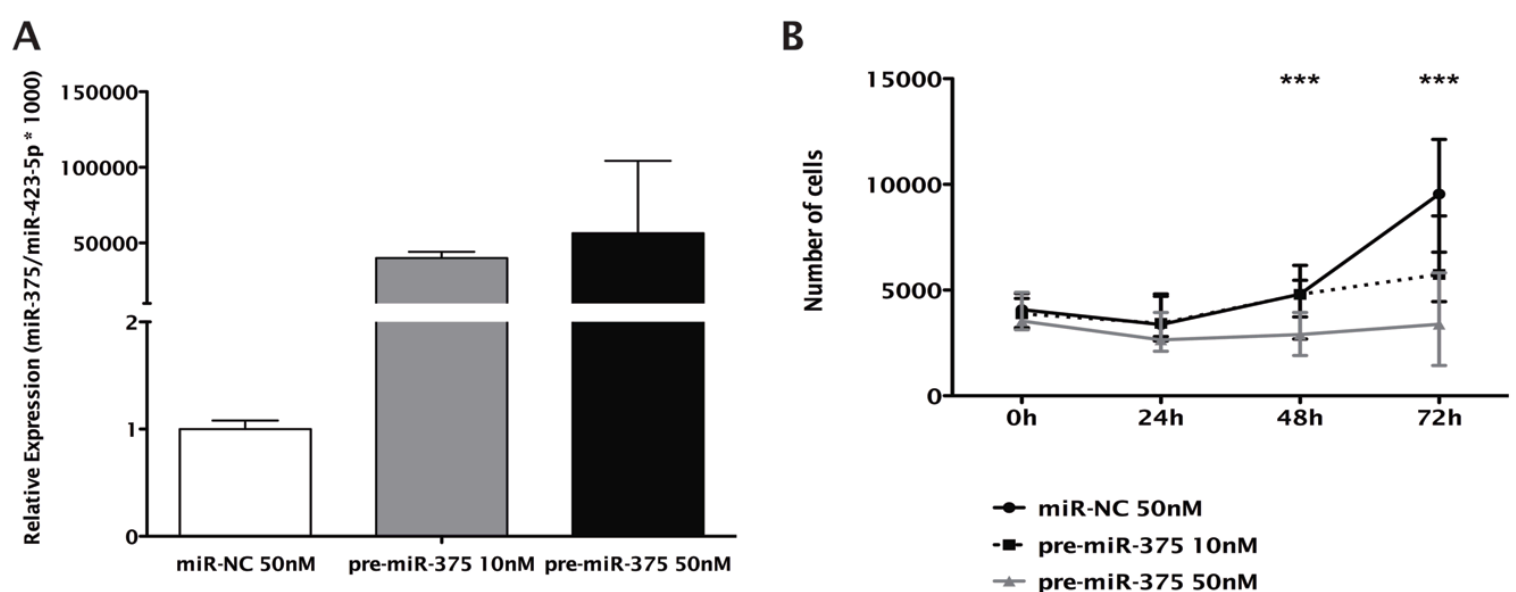

C

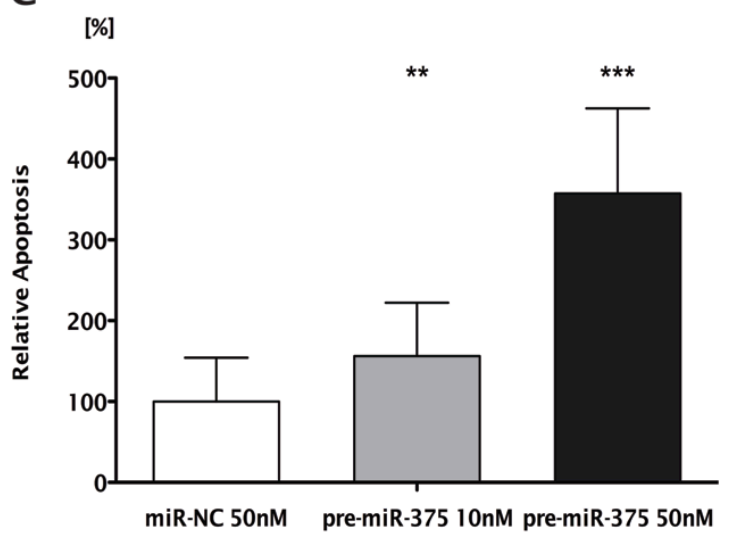

Figure 17. Forced expression of miR-375 in PC-3. (A) Relative expression of miR-375 (normalized to miR-NC), (B) Number of viable cells, (C) Relative apoptosis levels (normalized to miR-NC). (B,C) Data shown as the median of three independent experiments and range performed in triplicate $(* * * p<0.001 ; * * p<0.01)$.

PC-3 is a well-known highly invasive PCa cell line and we measured this feature upon pre-miR-375 transfection. We observed that this ability was 
diminished using both concentrations of precursor molecules compared with miR-NC transfected cells (10nM, $\mathrm{p}=0.002 ; 50 \mathrm{nM}, \mathrm{p}=0.002)$ (Figure 18). In fact, invasion was reduced by $30 \%$ and $55 \%$ in cells transfected with $10 \mathrm{nM}$ and $50 \mathrm{nM}$ pre-miR-375, respectively (Figure 18- D).
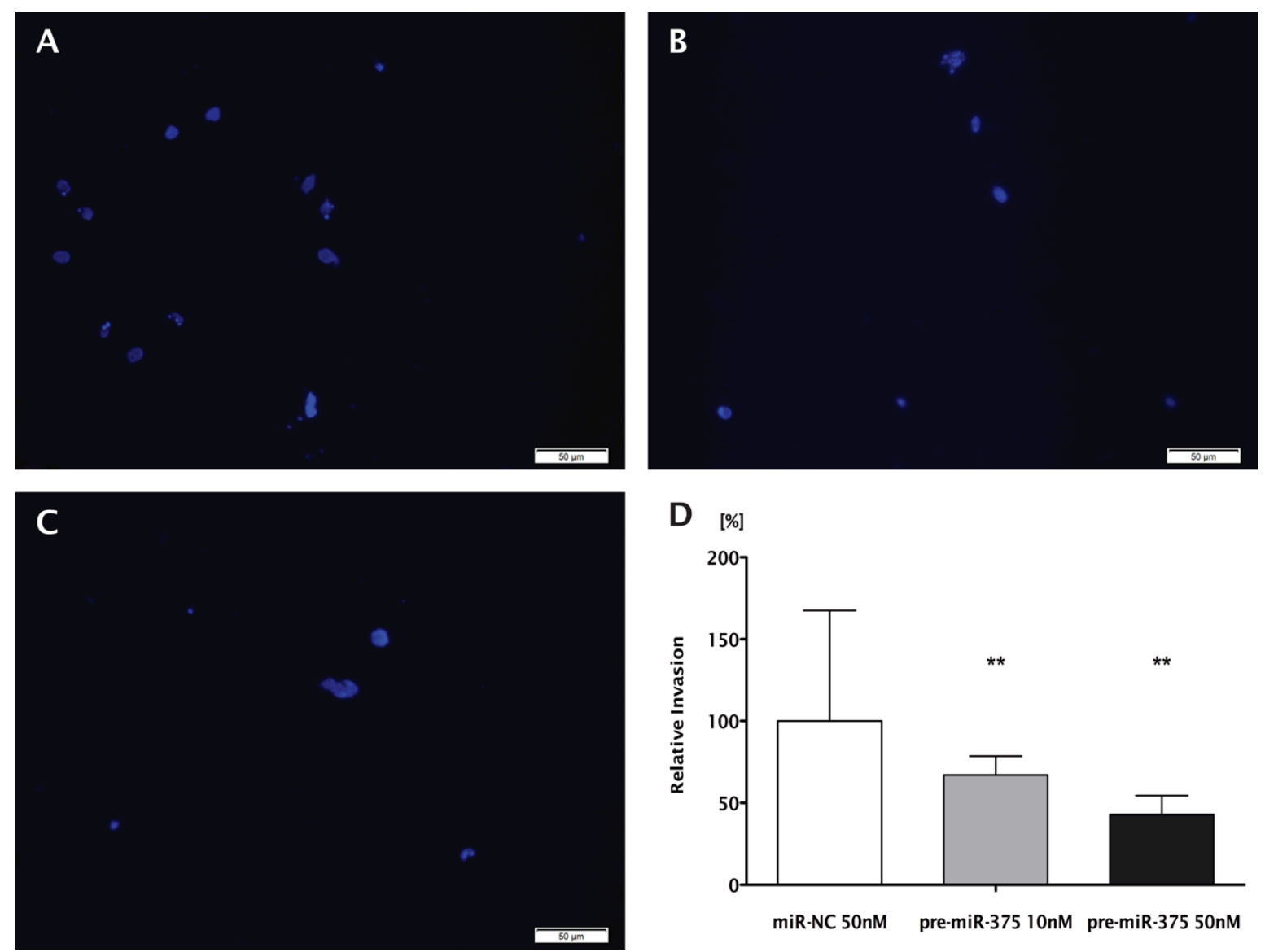

Figure 18. Invasion assay in PC-3 cell line. (A) miR-NC cells, (B) pre-miR-375 10nM and (C) pre-miR-375 50nM transfected cells, (D) percentage of PC-3 invading cells. (D) Data corresponds to median values of two independent experiments performed in triplicate (normalized to miR-NC) $(* * \mathrm{p}<0.01)$.

\section{MIR-375 SILENCING IN 22RV1: IMPACT ON CELL VIABILITY AND APOPTOSIS}

The effect of miR-375 silencing was also evaluated in 22Rv1, a PCa cell line that was previously shown to overexpress this miRNA. A 52\% decrease in expression was achieved with a transfection with the inhibitor at $25 \mathrm{nM}$ concentration, and of $68 \%$ with $50 \mathrm{nM}$ anti-miR-375 comparing with miR-NC cells (Figure 19- A). Silencing of miR-375 significantly reduced cell viability at both concentrations, 72 hours after transfection $(25 \mathrm{nM}, \mathrm{p}=0.002 ; 50 \mathrm{nM}, \mathrm{p}=0.007)$ (Figure 19- B). The number of viable cells was decreased in $21.61 \%(25 \mathrm{nM})$ and $16.84 \%(50 \mathrm{nM})$ after transfection when compared to miR-NC. 
Additionally, transfection with both concentrations of miR-375 inhibitor induced apoptosis in $22 \mathrm{Rv} 1$ cells. Specifically, an induction of $51 \%(25 \mathrm{nM}$, $\mathrm{p}<0.001)$ and $30 \%(50 \mathrm{nM}, \mathrm{p}=0.004)$ was obtained comparing with miR-NC transfected cells (Figure 19- B).
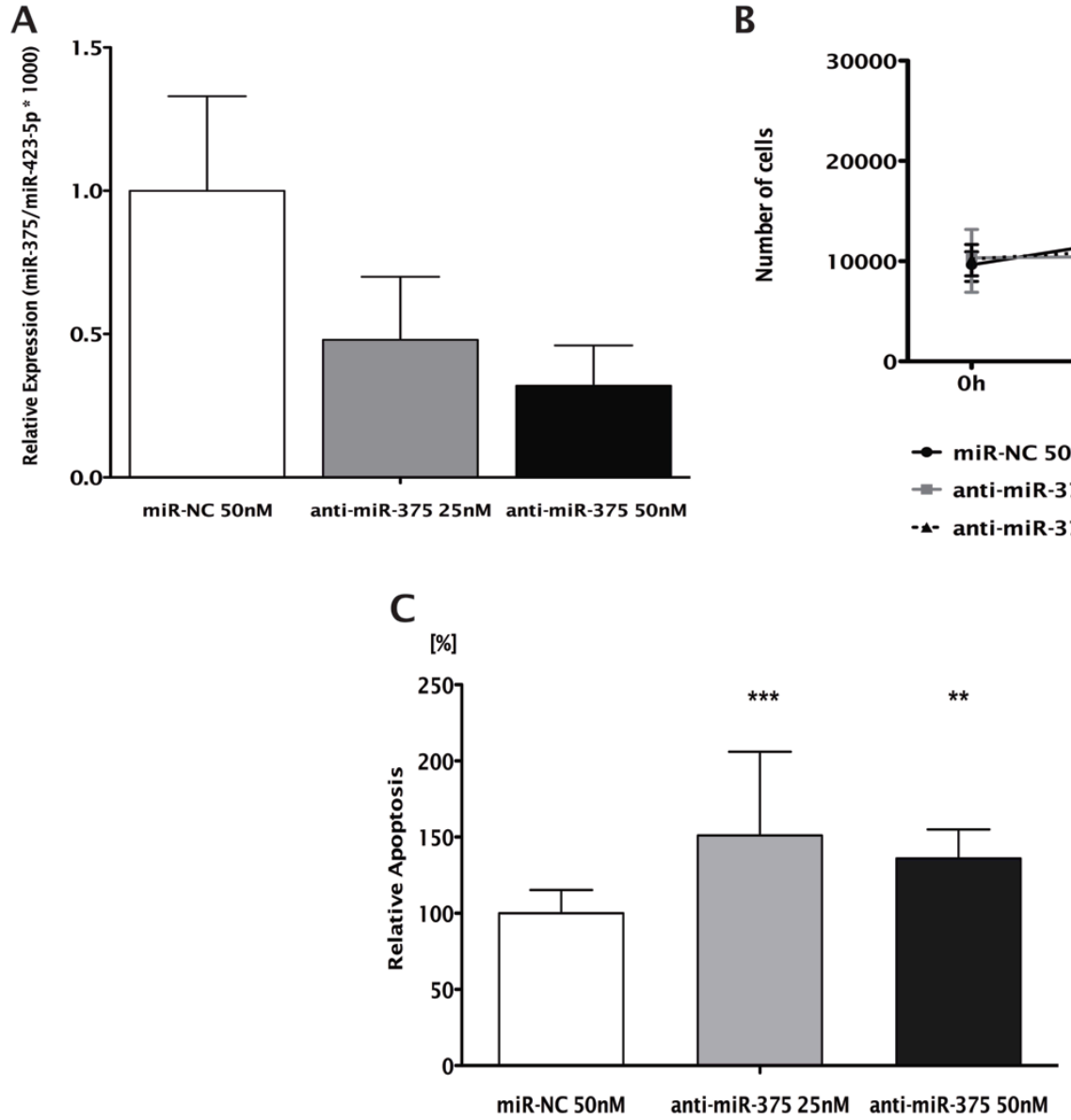

B

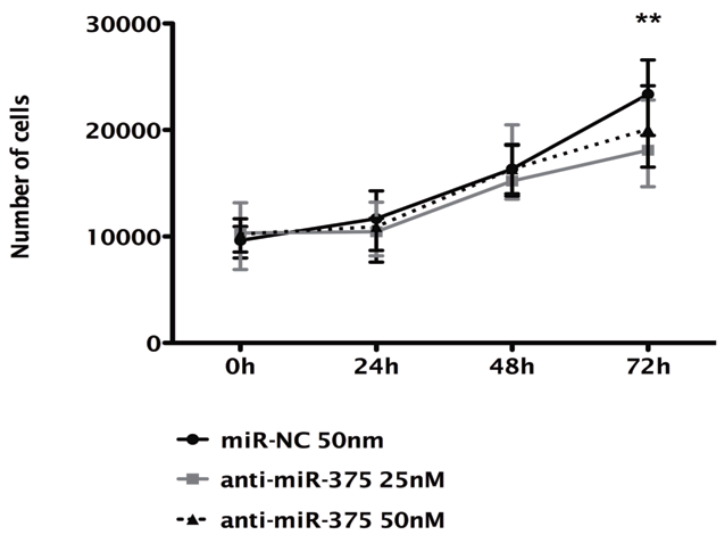

Figure 19. Inhibition of miR-375 in $22 \mathrm{Rv} 1$. (A) Relative expression of miR-375 (normalized to miR-NC), (B) Number of viable cells and (C) Relative apoptosis levels (normalized to miR-NC). (B,C) Data shown as the median and range of three independent experiments performed in triplicate $(* * * p<0.001 ; * * p<0.01)$.

\section{SEARCHING FOR POTENTIAL TARGETS OF MIR-375}

Aiming for discovery of potential targets of miR-375 in PCa, we used a platform consisting of 61 genes involved in some of the most important cellular pathways. Thus, this panel was analyzed in PC-3 cells transfected with 50nM premiR-375 and 22Rv1 cells transfected with 25nM anti-miR-375, which exhibited more impressive results in phenotypic assays. We also tested miR-NC transfected PC-3 and 22Rv1 cells, for control purposes. Results for each gene are presented in Figure 20. 

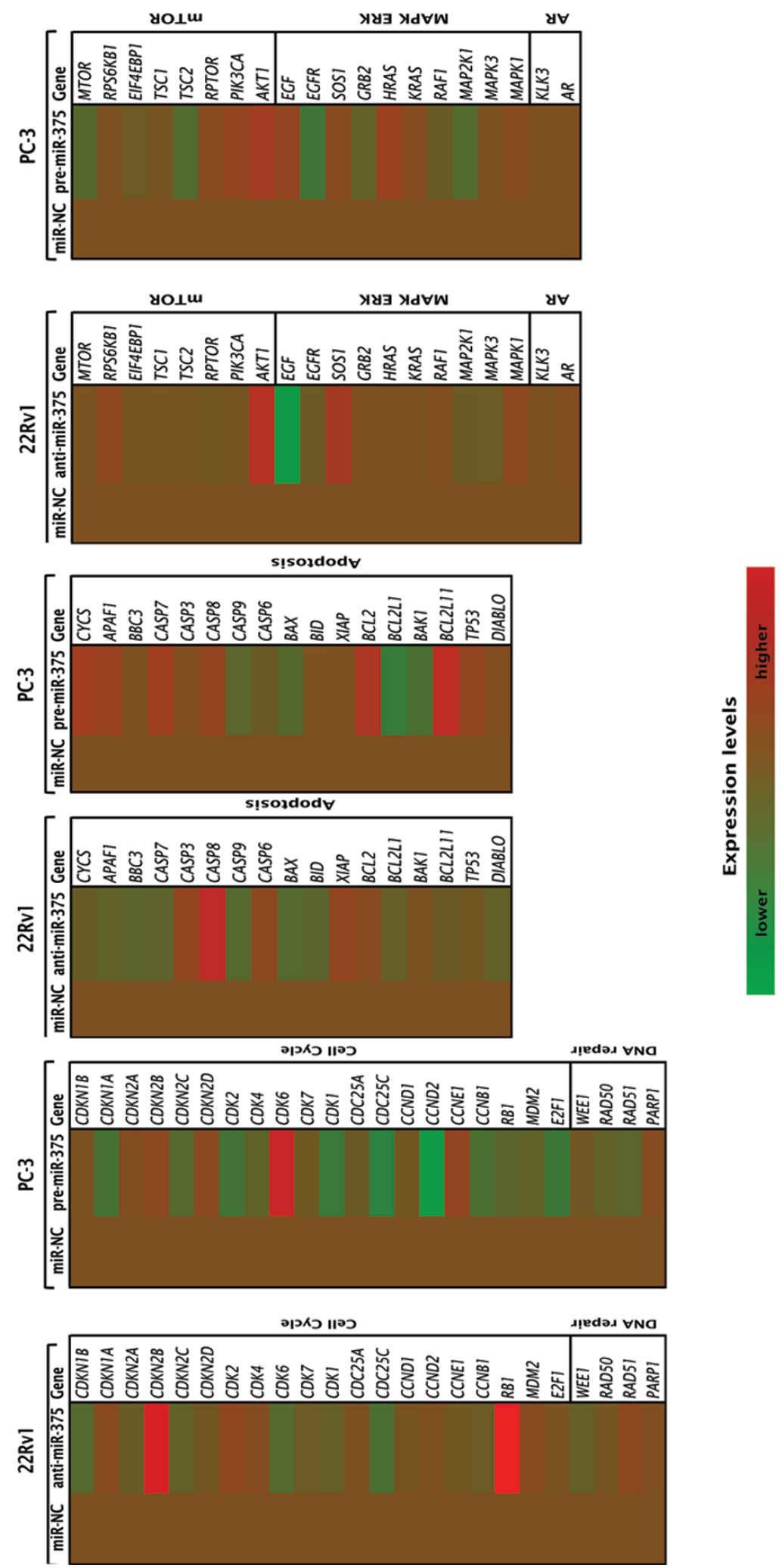

Figure 20. Results for genes included in the custom array normalized for miR-NC. 


\section{VALIDATION OF POTENTIAL TARGETS OF MIR-375}

Then, the identified miR-375's potential targets (Table 8) were validated by RT-qPCR in the same clinical samples used for evaluation of miR-375 expression and results are displayed in Figure 21.

Table 8. Genes more deregulated in opposite trends after miR-375 transfection.

\begin{tabular}{l|c|c}
\hline \multirow{2}{*}{ GENES } & \multicolumn{2}{|c}{ FOLD VARIATION AFTER TRANSFECTION } \\
\cline { 2 - 3 } & 22Rv1, anti-miR-375 & PC-3, pre-miR-375 \\
\hline$R B 1$ & 5.64 & -0.46 \\
\hline$C D K N 1 A(\mathrm{p} 21)$ & 0.12 & -0.68 \\
\hline$C D K 2$ & 0.18 & -0.73 \\
\hline$C C N D 2$ (CyclinD2) & 0 & -3.16 \\
\hline
\end{tabular}

Overall, these targets have opposite deregulation patterns upon induced expression and silencing of miR-375. Only $R B 1$ and CCND2 expression levels were significantly different between PCa and MNPT samples. RB 1 was found to be upregulated in PCa samples $(p=0.006)$, whereas CCND2 showed decreased levels in tumor samples when compared with normal prostate tissues $(p=0.008)$.
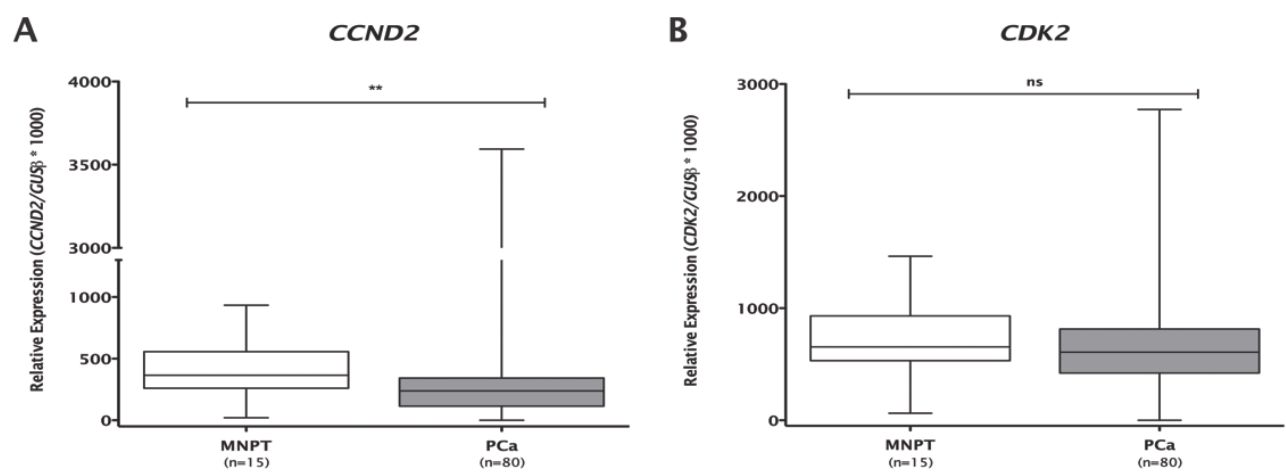

C

D

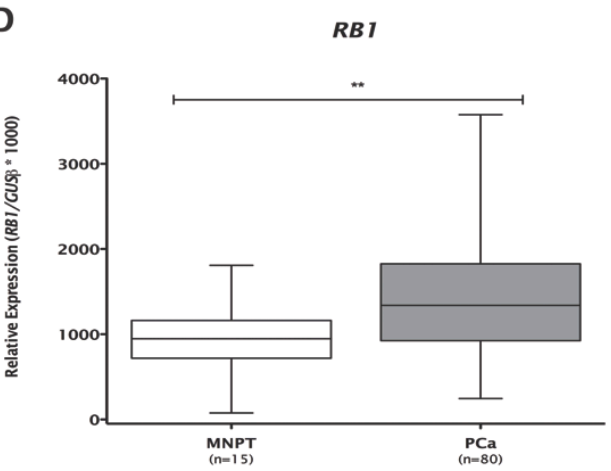

Figure 21. Expression levels of potential miR-375 targets for array validation. (A) CCND2, (B) CDK2, (C) CDKN1A and (D) RB1 (** $p<0.01$; ns - non-significant). 


\section{Pathways affected following MiR-375 Deregulation}

In order to elucidate which pathways were deregulated upon miR-375's transfection in both PCa cell lines, a gene ontology enrichment analysis was performed. In Figure 22, results for genes downregulated after miR-375 reexpression in PC-3 (A) and upregulated after respective silencing in 22Rv1 (B) are displayed. Pathways with higher enrichment values for opposite analysis corresponded to two major cellular functions: cell cycle regulation and phosphorylation.

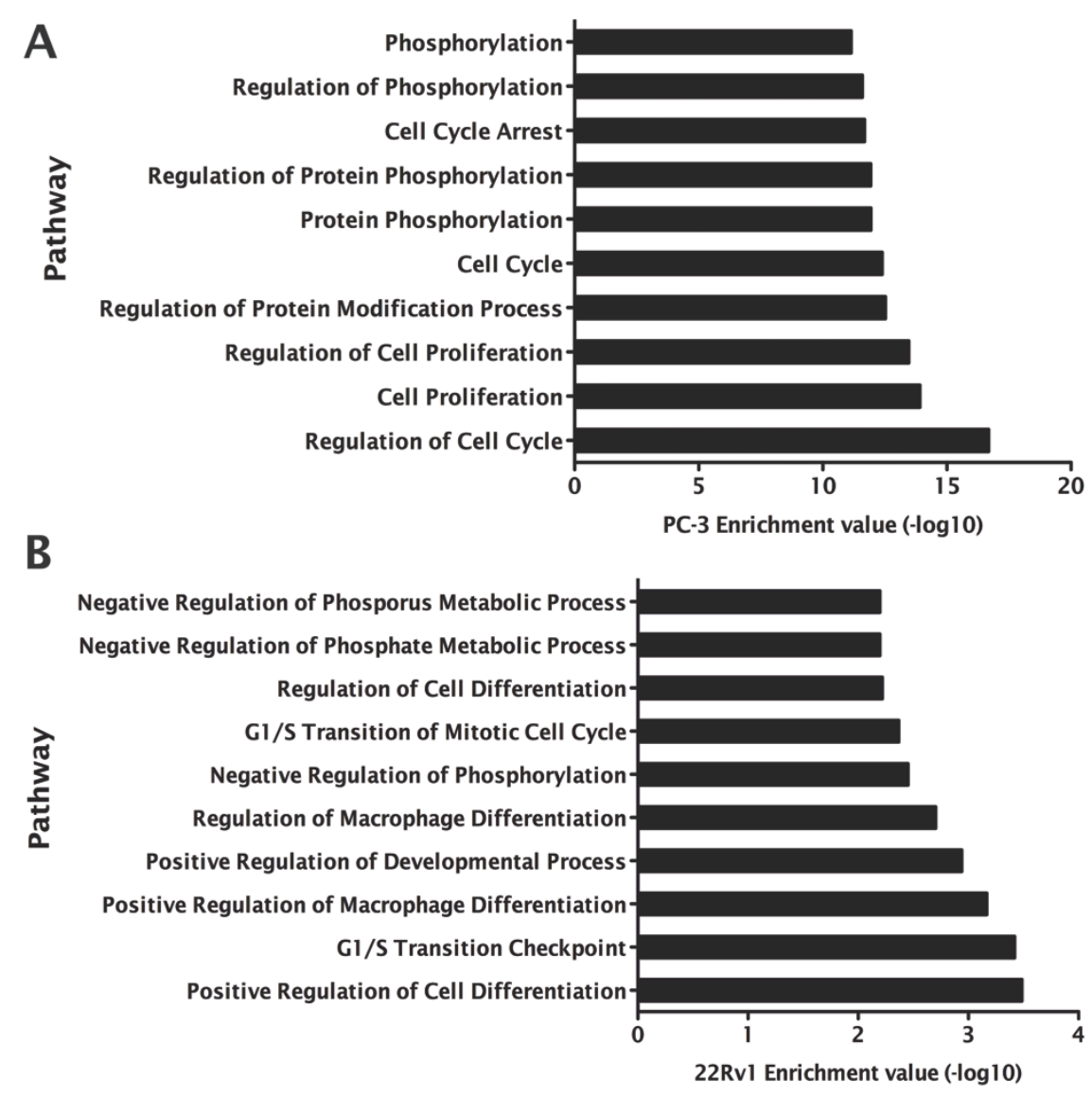

Figure 22. GO enrichment: deregulated pathways: (A) downregulated in PC-3 and (B) upregulated in 22Rv1 transfected cells. 


\section{DISCUSSION}

PCa is still a major health concern worldwide, mainly due to insufficient biological knowledge about its onset and progression [1]. Despite having brought expectations for an earlier and more accurate detection of PCa, the serum PSA test has become controversial due to its lack of specificity [27]. Therefore, there is an urge to increase current knowledge about the biology of PCa development, to improve both detection and treatment options in an individual approach. Epigenetic mechanisms have emerged in recent decades as new tools to understand the tumorigenesis process [107]. MicroRNAs are a "hot" field in research; since their functional importance within cellular context has been uncovered. Regarding cancer, most studies have been focused in ascertain specific profiles of miRNAs expression for different types of tumors when compared with their normal tissues [133, 134]. PCa is no exception and several studies attempted to distinguish prostate tumors from normal prostatic tissues, but not always the profiles generated were congruent [97, 99]. One of the major pitfalls of these studies is the lack of validation in a larger set of samples and of the impact of specific miRNA deregulation in PCa in vitro models [106]. Therefore our initial approach consisted in the discovery, for a limited number of samples, which miRNAs were upregulated in PCa compared to MNPT. We reached a list of 17 miRNAs, from which miR-449a has been already studied in a different study form our group (unpublished data), thus being excluded from this Thesis. Then, also based on other previously published microarray studies on miRNAs in PCa, we decided to start validating 3 of those miRNAs: miR-32, miR-182 and miR-375 $[98,99]$. Our study presents a significant difference when compared with other published works within the same scope: the use of normal prostate tissues derived from patients not harboring PCa. This is indeed a major advantage since it avoids potential contamination during specimen collection and nucleic acid extraction, assuring that all the differences found between MNPT and PCa are real and genuine.

MiR-32 was described in 2006 as overexpressed in colorectal and pancreatic cancer [106]. Moreover, and also for colorectal cancer, overexpression of this miRNA was associated with cell growth promotion, migration, invasion and apoptosis reduction [135, 136]. Mir-32 overexpression was also associated with poor outcome in kidney tumors [137]. Concerning PCa, miR-32 was firstly 
reported as differentially expressed in a global miRNA expression study in which the authors have used matched samples collected from the prostates harboring cancer as controls [138]. Nevertheless, miR-32 was the most significantly upregulated miRNA followed by miR-182, also evaluated in this thesis. Interestingly, in this same study, Bcl-2 interacting mediator of cell death (Bim), a proapoptotic member of the BCL-2 family, was identified as a miR-32's target. More recently, miR-32 was reported as overexpressed in CRPC but not in PCa samples, suggesting a hormone dependent role [139]. Transfection of this miRNA into the androgen-sensitive LNCaP cell line resulted in increased cell growth. However, when exposed to low levels of androgens, growth enhancement was diminished. The same authors found that this effect was related with apoptosis reduction, and identified BTC family member 2 (BTC2) as a direct target for miR32 in CRPC samples, in which it is downregulated. Importantly, Jalava and coauthors hypothesized that miR-32/BTG2 form a positive feedback loop of $A R$ signaling in PCa. Interestingly, we found miR-32 overexpression in the small set used for microarray platform, but we were unable to validate that result in a larger samples set. Our findings suggest that miR-32 might be implicated in a subset of PCa, as it occurs in CRPC, which is in accordance with Jalava et al. Additionally, our findings demonstrate the need of microarray platform validation in a larger and mostly independent set of samples to obtain reliable results.

Regarding the second miRNA selected for validation in our study, miR182, available data on its role in tumorigenesis is rather contradictory. Depending on the tumor model, miR-182 seems to act as a tumor suppressor as suggested for lung and gastric cancers [140, 141], or to play an oncogenic function, such as in melanoma, and ovarian, hepatocellular, and breast cancers [142-145]. Indeed, in lung cancer cell lines miR-182 exogenous expression diminished invasion and proliferation abilities through cortactin (CTTN) downregulation [140]. Concerning the latter function, in breast cancer miR-182 overexpression has been linked to forkhead box 01 (FOXO1) (tumor-suppressor) downregulation, together with miR-27a and miR-96 [146]. Moreover, the same authors demonstrated in vitro that inhibition of these miRNAs increased expression of FOXO1. The same oncogenic role has been recently reported for miR-182, by suppressing missing in metastasis (MIM) gene and promoting RhoA activation promoting tumor cell invasion and metastasis in vitro [145]. In this study, miR-182 was also implicated in cytoskeleton dynamics and metastatic properties of breast cancer cells [145]. 
Nonetheless, for PCa, at the time of the beginning of our study, only one report showing overexpression in malignant lesions was available [138]. In the current year, however, five studies were published, and we thus decided not to perform further studies, such as phenotypic and target validation assays [147151]. Importantly, our results, both from the array and the validation set, corroborate those found by others. According to Tsuchiyama and collaborators, miR-182 expression levels are associated with GS, suggesting its use as high grade PCa marker in biopsy samples [151]. Contrarily, we were not able to find any correlation between miR-182 expression and any of the clinical variables. Additionally, in several other studies miR-182 was found to directly target numerous genes such as guanine nucleotide binding protein (G protein) alpha 13 (GNA13), snail homolog 2 (SNAI2), N-myc downstream regulated 1 (NDRG1), reversion-inducing-cysteine-rich protein with kazal motifs (RECK), forkhead box F2 (FOXF2) and metastasis suppressor 1 (MTSS1) in PCa [147-150]. In all these independent studies, miR-1 82 inhibition decreased cell proliferation, invasion and migration in vitro, as well as tumors volume reduction in vivo assays. However, the mechanism underlying miR-182 overexpression in PCa still needs to be elucidated. Strikingly, amplification of the genomic region where miR-182 is mapped was already demonstrated and associated with PCa aggressiveness [152, 153].

Finally, as regards to miR-375, the third miRNA addressed in this Thesis, mostly the data gathered on malignant lesions support its role as a tumor suppressor. This miRNA was reported to be downregulated in gastric, head and neck, pancreatic and hepatocellular carcinoma [154-157]. In fact for gastric cancer, its reexpression in vitro increased apoptosis and led to cell viability reduction [157]. In a parallel study, also in gastric carcinoma, janus kinase 2 (JAK2) was identified as a direct target of miR-375 and their expression was inversely correlated [158]. Similarly, in breast cancer cells, miR-375's in vitro inhibition was associated with lower cell proliferation rates [159] and was proposed to function as an estrogen receptor $(E R \alpha)$ signaling activator. Interestingly, in some breast cancer cells, miR-375 downregulation was associated with a repressive chromatin status in the miR-375 locus, suggesting the existence of a positive loop between ER $\alpha$ and miR-375 [159]. Furthermore, in oral cancer, a similar function has been observed concerning proliferation inhibition along with impairment of migration and invasion [160], supporting the anti-oncogenic role described for other tumors. The same research group 
identified a gene responsible for stabilizing the protein $M Y C$, the cancerous inhibitor of PP2A (CIP2A) as a direct target of miR-375 [160]. Herein, we evaluated miR-375 expression levels in PCa samples compared with MNPT and using in vitro assays assessed the phenotypic impact of its ectopic expression and silencing in PCa cell lines. As far as we know, this is the first study investigating the role of miR-375 in prostate carcinogenesis. Until now, miR-375 has only been studied by microarray platforms or in validation platforms to find groups of miRNAs capable of distinguishing PCa from normal tissues [161-165]. Additionally, two studies from Nguyen et al. and Cheng et al. showed that miR375 expression levels were related with disease progression, advocating its usefulness as a tumor biomarker. Our results both from microarray analysis and subsequent validation are in the same lines, although we did not disclosed any significant association between miR-375 expression levels and Gleason Score or pathologic staging.

Importantly, PCa cell lines also displayed miR-375 overexpression in comparison with the normal prostate cell line, RWPE-1. After transfecting RWPE-1 cells with precursor molecules of miR-375, however, no significant phenotypic effects differences were observed. Unexpectedly, miR-375 ectopic expression in PC-3 resulted in decreased cell viability, and invasion, concomitant with an enhancement of apoptotic levels, supporting a tumor suppressor role in this in vitro model. Contrarily, in $22 \mathrm{Rv} 1$ cells (which display the highest expression levels), miR-375 silencing induced a reduction in cell viability and increased apoptosis. Interestingly, similar phenotypic effects were observed using two different concentrations for miR-375 inhibition. However, the most significant impact was depicted using the lowest concentration. We speculate that this might be due to the fact that a more efficient miR-375 silencing could not reverse the malignant phenotype for $22 \mathrm{Rv} 1$ cell line, resembling the low expression levels of PC-3 cells.

Taking these results into account along with the overexpression found in PCa samples, miR-375 seems to play a dual role in prostatic carcinogenesis. In order to further clarify miR-375 function in PCa we investigated its specific targets. Hence, we performed a microarray analysis assessing 61 genes, involved in critical cellular pathways, in PC-3 cells with ectopic miRNA expression and $22 \mathrm{Rv} 1$ cells silenced for miR-375, and compared them with their respective negative control. 
After gene ontology enrichment analysis, our data implicated miR-375 in cell cycle regulation. We then selected deregulated genes common to both experiments for validation by RT-qPCR in the same set of samples used for miRNA validation. After validation, only $R B 1$ and CCND2 were differentially expressed in PCa cells. Importantly, only CCND2 was underexpressed in PCa samples as might be presumed for a target of an overexpressed miRNA. We have previously reported that CCND2 was downregulated in $\mathrm{PCa}$ in association with gene promoter hypermethylation [166]. Nonetheless, miR-375 might constitute an alternative mechanism for CCND2 deregulation in $\mathrm{PCa}$, acting in concert with aberrant DNA methylation. Regarding $R B 1$, its loss of expression due to genetic and epigenetic alterations in PCa is well documented, which contradicts our results [167]. Remarkably, in colon cancer, $R B 1$ is normally transcribed but there is no $R B 1$ protein expression [106]. We, thus, hypothesize that a similar same mechanism might occur in PCa. Regarding other putative targets, Sec23A protein (which mediates protein transport from the endoplasmic reticulum to the Golgi apparatus) has been suggested as a target for miR-375 in PCa [161]. However, that study was based only in gain and loss of function experiments with this protein and not with miR-375 expression levels, not providing direct evidence of this regulatory connection.

Although our study in the first to show, in vitro, miR-375 involvement in prostatic carcinogenesis, the elucidation of the target genes requires further investigation. 


\section{CONCLUSIONS AND FUTURE PERSPECTIVES}

In this study, no differences in expression levels were disclosed for miR32 in PCa samples compared to MNPT, contradicting previous reports. However, none of those performed adequate validation of expression data in an independent series of patients, as we did.

Concerning miR-182, we confirmed results from other groups and hypothesized that its overexpression might be due to genomic amplification. In fact, we intend to verify if this hypothesis in primary PCa samples.

Regarding miR-375, which constituted the main focus of this study, we demonstrated its overexpression both in in PCa tissue samples and in PCa cell lines. Moreover, gain of function experiments in RWPE-1 cells did not disclose any phenotypic impact, suggesting that miR-375 overexpression is not sufficient to transform benign prostate epithelial cells. Strikingly, miR-375 silencing in a PCa cell line $(22 R v 1)$ displaying the highest levels of expression and miR-375 forced expression in PC-3 cells (which displayed the lowest expression levels) resulted in similar phenotypic effects on cell viability and apoptosis. In PC-3, reduced invasion ability was also observed following miR-375 induced expression. Hence, in the same cancer model, this particular miRNA might play a dual role, either as an oncogene or a tumor-suppressor, a feature that requires further elucidation.

As we found that miR-375 might be involved in cell cycle regulation, it is our purpose to test the impact of its deregulation in cell cycle of PCa cells.

We also intend to perform luciferase assays to validate potential target genes of miR-375 after in silico search.

Regarding CCND2, our results suggest this gene is a potential target of miR-375, but additional studies are needed to confirm this hypothesis. 


\section{REFERENCES}

1. Shen MM, Abate-Shen C. (2010) Molecular genetics of prostate cancer: new prospects for old challenges. Genes \& development.24(1 8):1967-2000.

2. DeVita VT, Lawrence TS, Rosenberg SA. (2008) Cancer: Principles \& Practice of Oncology. Wolters Kluwer/Lippincott Williams \& Wilkins.

3. Hricak H, Scardino PT. (2009) Prostate cancer. Cambridge University Press.

4. Abate-Shen C, Shen MM. (2000) Molecular genetics of prostate cancer. Genes \& development. 14(19):2410-34.

5. Alcaraz A, Hammerer P, Tubaro A, Schroder FH, Castro R. (2009) Is there evidence of a relationship between benign prostatic hyperplasia and prostate cancer? Findings of a literature review. Eur Urol.55(4):864-73.

6. Kasper DL. (2005) Harrison's Principles of Internal Medicine. 16th edition ed. McGraw-Hill.

7. Briganti A, Capitanio U, Suardi N, Gallina A, Salonia A, Bianchi M, et al. (2009) Benign Prostatic Hyperplasia and Its Aetiologies. European Urology Supplements.8(13):865-71.

8. Epstein Jl. (2009) Precursor lesions to prostatic adenocarcinoma. Virchows Archiv : an international journal of pathology.454(1):1-16.

9. Ramon J, Denis L. (2007) Prostate Cancer. Springer, Berlin.

10. Bostwick DG, Cheng L. (2012) Precursors of prostate cancer. Histopathology.60(1):4-27.

11. Chrisofos M, Papatsoris AG, Lazaris A, Deliveliotis C. (2007) Precursor lesions of prostate cancer. Critical reviews in clinical laboratory sciences.44(3):243-70.

12. Ferlay J SH, Bray F, Forman D, Mathers C and Parkin DM. (2010) GLOBOCAN 2008: Cancer Incidence and Mortality Worldwide v2.0.

13. Damber JE, Aus G. (2008) Prostate cancer. Lancet.371(9625):1710-21.

14. Baade PD, Youlden DR, Krnjacki LJ. (2009) International epidemiology of prostate cancer: geographical distribution and secular trends. Molecular nutrition $\&$ food research.53(2):171-84.

15. Brawley OW. (2012) Prostate cancer epidemiology in the United States. World journal of urology.30(2):195-200.

16. Ferlay J, Shin HR, Bray F, Forman D, Mathers C, Parkin DM. (2010) Estimates of worldwide burden of cancer in 2008: GLOBOCAN 2008. International journal of cancer Journal international du cancer.127(12):2893-917.

17. Center MM, Jemal A, Lortet-Tieulent J, Ward E, Ferlay J, Brawley O, et al. (2012) International variation in prostate cancer incidence and mortality rates. Eur Urol.61 (6): 1079-92. 
18. Chornokur G, Dalton K, Borysova ME, Kumar NB. (2011) Disparities at presentation, diagnosis, treatment, and survival in African American men, affected by prostate cancer. The Prostate.71(9):985-97.

19. Boyd LK, Mao X, Lu YJ. (2012) The complexity of prostate cancer: genomic alterations and heterogeneity. Nature reviews Urology.9(11):652-64.

20. Bostwick DG, Burke HB, Djakiew D, Euling S, Ho SM, Landolph J, et al. (2004) Human prostate cancer risk factors. Cancer.101(10 Suppl):2371-490.

21. Kirby RS, Fitzpatrick JM, Irani J. (2009) Prostate cancer diagnosis in the new millennium: strengths and weaknesses of prostate-specific antigen and the discovery and clinical evaluation of prostate cancer gene 3 (PCA3). BJU international. 103(4):441-5.

22. Eble JL, Sauter G, Epstein JI, Sesterhenn IA. (2004) Pathology and Genetics of Tumours of the Urinary System and Male Genital Organs: WHO Classification of Tumours. World Health Organization.

23. Wolf AM, Wender RC, Etzioni RB, Thompson IM, D'Amico AV, Volk RJ, et al. (2010) American Cancer Society guideline for the early detection of prostate cancer: update 2010. CA: a cancer journal for clinicians.60(2):70-98.

24. Heidenreich A, Bellmunt J, Bolla M, Joniau S, Mason M, Matveev V, et al. (2011) EAU guidelines on prostate cancer. Part 1: screening, diagnosis, and treatment of clinically localised disease. Eur Urol.59(1):61-71.

25. Barry MJ. (2001) Clinical practice. Prostate-specific-antigen testing for early diagnosis of prostate cancer. The New England journal of medicine.344(18):13737.

26. Crawford ED. (2003) Epidemiology of prostate cancer. Urology.62(6 Suppl 1):3-12.

27. Duffy MJ. (2011) Prostate-specific antigen: does the current evidence support its use in prostate cancer screening? Annals of Clinical Biochemistry.48(4 \%U http://acb.rsmjournals.com/content/48/4/310.abstract):310-6.

28. Lotan TL, Epstein Jl. (2010) Clinical implications of changing definitions within the Gleason grading system. Nature reviews Urology.7(3):136-42.

29. Iczkowski KA, Lucia MS. (2011) Current perspectives on Gleason grading of prostate cancer. Current urology reports.12(3):216-22.

30. Epstein Jl. (2010) An update of the Gleason grading system. The Journal of urology. 183(2):433-40.

31. Cheng L, Montironi R, Bostwick DG, Lopez-Beltran A, Berney DM. (2012) Staging of prostate cancer. Histopathology.60(1):87-117.

32. Edge SB, Compton CC. (2010) The American Joint Committee on Cancer: the 7th edition of the AJCC cancer staging manual and the future of TNM. Annals of surgical oncology.17(6):1471-4.

33. Edge S, Byrd D, Compton C. (2010) AJCC Cancer Staging Manual 7th Edition. Springer, New York.

34. Falzarano SM, Magi-Galluzzi C. (2011) Prostate cancer staging and grading at radical prostatectomy over time. Advances in anatomic pathology.18(2):15964. 
35. Jani $A B$, Hellman S. (2003) Early prostate cancer: clinical decision-making. Lancet.361(9362):1045-53.

36. Hammerer P, Madersbacher S. (2012) Landmarks in hormonal therapy for prostate cancer. BJU international.1 10 Suppl 1:23-9.

37. Carles J, Castellano D, Climent MA, Maroto P, Medina R, Alcaraz A. (2012) Castration-resistant metastatic prostate cancer: current status and treatment possibilities. Clinical \& translational oncology : official publication of the Federation of Spanish Oncology Societies and of the National Cancer Institute of Mexico.14(3):169-76.

38. Felici A, Pino MS, Carlini P. (2012) A changing landscape in castrationresistant prostate cancer treatment. Frontiers in endocrinology.3:85.

39. Cooperberg MR, Broering JM, Carroll PR. (2010) Time trends and local variation in primary treatment of localized prostate cancer. Journal of clinical oncology : official journal of the American Society of Clinical Oncology.28(7): $1117-23$.

40. Esteller M. (2008) Epigenetics in cancer. The New England journal of medicine.358(11):1148-59.

41. Sandoval J, Esteller M. (2012) Cancer epigenomics: beyond genomics. Current opinion in genetics \& development.22(1):50-5.

42. Sharma S, Kelly TK, Jones PA. (2010) Epigenetics in cancer. Carcinogenesis.31(1):27-36.

43. Rodriguez-Paredes M, Esteller M. (2011) Cancer epigenetics reaches mainstream oncology. Nature medicine.17(3):330-9.

44. Portela A, Esteller M. (2010) Epigenetic modifications and human disease. Nature biotechnology.28(10):1057-68.

45. Kanwal R, Gupta S. (2012) Epigenetic modifications in cancer. Clinical genetics.81(4):303-11.

46. Sincic N, Herceg Z. (2011) DNA methylation and cancer: ghosts and angels above the genes. Current opinion in oncology.23(1):69-76.

47. Jones PA. (2012) Functions of DNA methylation: islands, start sites, gene bodies and beyond. Nature reviews Genetics.13(7):484-92.

48. De Carvalho DD, You JS, Jones PA. (2010) DNA methylation and cellular reprogramming. Trends in cell biology.20(10):609-17.

49. Turek-Plewa J, Jagodzinski PP. (2005) The role of mammalian DNA methyltransferases in the regulation of gene expression. Cellular $\&$ molecular biology letters. 10(4):631-47.

50. Cedar H, Bergman Y. (2012) Programming of DNA methylation patterns. Annual review of biochemistry.81:97-117.

51. Zentner GE, Henikoff S. (2013) Regulation of nucleosome dynamics by histone modifications. Nature structural \& molecular biology.20(3):259-66.

52. Dawson MA, Kouzarides T, Huntly BJ. (2012) Targeting epigenetic readers in cancer. The New England journal of medicine.367(7):647-57. 
53. Musselman CA, Lalonde ME, Cote J, Kutateladze TG. (2012) Perceiving the epigenetic landscape through histone readers. Nature structural \& molecular biology.19(12):1218-27.

54. Kouzarides T. (2007) Chromatin modifications and their function. Cell.128(4):693-705.

55. Bannister AJ, Kouzarides T. (2011) Regulation of chromatin by histone modifications. Cell research.21(3):381-95.

56. Strahl BD, Allis CD. (2000) The language of covalent histone modifications. Nature.403(6765):41-5.

57. Waldmann T, Schneider R. (2013) Targeting histone modificationsepigenetics in cancer. Current opinion in cell biology.25(2):184-9.

58. Costa FF. (2009) Non-coding RNAs and new opportunities for the private sector. Drug discovery today.14(9-10):446-52.

59. Batista PJ, Chang HY. (2013) Long noncoding RNAs: cellular address codes in development and disease. Cell.152(6):1298-307.

60. Esteller M. (2011) Non-coding RNAs in human disease. Nature reviews Genetics.12(12):861-74.

61. Sabin LR, Delas MJ, Hannon GJ. (2013) Dogma derailed: the many influences of RNA on the genome. Molecular cell.49(5):783-94.

62. Mercer TR, Dinger ME, Mattick JS. (2009) Long non-coding RNAs: insights into functions. Nature reviews Genetics. 10(3):155-9.

63. Costa FF. (2008) Non-coding RNAs, epigenetics and complexity. Gene.410(1):9-17.

64. Croce CM. (2009) Causes and consequences of microRNA dysregulation in cancer. Nature reviews Genetics.10(10):704-14.

65. Iorio MV, Croce CM. (2009) MicroRNAs in cancer: small molecules with a huge impact. Journal of clinical oncology : official journal of the American Society of Clinical Oncology.27(34):5848-56.

66. van Rooij E, Olson EN. (2012) MicroRNA therapeutics for cardiovascular disease: opportunities and obstacles. Nature reviews Drug discovery.11(11):86072.

67. Iorio MV, Croce CM. (2012) MicroRNA dysregulation in cancer: diagnostics, monitoring and therapeutics. A comprehensive review. EMBO molecular medicine.4(3): 143-59.

68. Melo SA, Esteller M. (2011) Dysregulation of microRNAs in cancer: playing with fire. FEBS letters.585(13):2087-99.

69. Treiber T, Treiber N, Meister G. (2012) Regulation of microRNA biogenesis and function. Thrombosis and haemostasis.107(4):605-10.

70. Tetreault N, De Guire V. (2013) miRNAs: Their discovery, biogenesis and mechanism of action. Clinical biochemistry.46(10-11):842-5.

71. Pasquinelli AE. (2012) MicroRNAs and their targets: recognition, regulation and an emerging reciprocal relationship. Nature reviews Genetics.13(4):271-82. 
72. Vasudevan S, Tong Y, Steitz JA. (2007) Switching from repression to activation: microRNAs can up-regulate translation. Science.318(5858):1931-4.

73. Filipowicz W, Bhattacharyya SN, Sonenberg N. (2008) Mechanisms of posttranscriptional regulation by microRNAs: are the answers in sight? Nature reviews Genetics.9(2):102-14.

74. Beitzinger M, Meister G. (2010) Preview. MicroRNAs: from decay to decoy. Cell.140(5):612-4.

75. Gonzalez S, Pisano DG, Serrano M. (2008) Mechanistic principles of chromatin remodeling guided by siRNAs and miRNAs. Cell Cycle.7(16):2601-8.

76. Kim DH, Saetrom P, Snove O, Jr., Rossi JJ. (2008) MicroRNA-directed transcriptional gene silencing in mammalian cells. Proceedings of the National Academy of Sciences of the United States of America.105(42):16230-5.

77. Khraiwesh B, Arif MA, Seumel GI, Ossowski S, Weigel D, Reski R, et al. (2010) Transcriptional control of gene expression by microRNAs. Cell.140(1):11122.

78. Witkos TM, Koscianska E, Krzyzosiak WJ. (2011) Practical Aspects of microRNA Target Prediction. Current molecular medicine. 11 (2):93-109.

79. Friedman RC, Farh KK, Burge CB, Bartel DP. (2009) Most mammalian mRNAs are conserved targets of microRNAs. Genome research.19(1):92-105.

80. Krek A, Grun D, Poy MN, Wolf R, Rosenberg L, Epstein EJ, et al. (2005) Combinatorial microRNA target predictions. Nature genetics.37(5):495-500.

81. Wang X, Wang X. (2006) Systematic identification of microRNA functions by combining target prediction and expression profiling. Nucleic acids research.34(5):1646-52.

82. Baek D, Villen J, Shin C, Camargo FD, Gygi SP, Bartel DP. (2008) The impact of microRNAs on protein output. Nature.455(7209):64-71.

83. Easow G, Teleman AA, Cohen SM. (2007) Isolation of microRNA targets by miRNP immunopurification. RNA.13(8):1198-204.

84. Davis S, Lollo B, Freier S, Esau C. (2006) Improved targeting of miRNA with antisense oligonucleotides. Nucleic acids research.34(8):2294-304.

85. Olejniczak M, Galka P, Krzyzosiak WJ. (2010) Sequence-non-specific effects of RNA interference triggers and microRNA regulators. Nucleic acids research.38(1):1-16.

86. Calin GA, Dumitru CD, Shimizu M, Bichi R, Zupo S, Noch E, et al. (2002) Frequent deletions and down-regulation of micro- RNA genes miR 15 and miR16 at 13 q14 in chronic lymphocytic leukemia. Proceedings of the National Academy of Sciences of the United States of America.99(24):15524-9.

87. Davalos V, Esteller M. (2010) MicroRNAs and cancer epigenetics: a macrorevolution. Current opinion in oncology.22(1):35-45.

88. Nelson KM, Weiss GJ. (2008) MicroRNAs and cancer: past, present, and potential future. Molecular cancer therapeutics.7(12):3655-60.

89. Garzon R, Marcucci G, Croce CM. (2010) Targeting microRNAs in cancer: rationale, strategies and challenges. Nature reviews Drug discovery.9(10):775-89. 
90. Jansson MD, Lund AH. (2012) MicroRNA and cancer. Molecular oncology.6(6):590-610.

91. Choudhry H, Catto JW. (2011) Epigenetic regulation of microRNA expression in cancer. Methods Mol Biol.676:165-84.

92. Zhang B, Pan X, Cobb GP, Anderson TA. (2007) microRNAs as oncogenes and tumor suppressors. Developmental biology.302(1):1-12.

93. Garzon R, Calin GA, Croce CM. (2009) MicroRNAs in Cancer. Annual review of medicine.60:167-79.

94. Schetter AJ, Leung SY, Sohn JJ, Zanetti KA, Bowman ED, Yanaihara N, et al. (2008) MicroRNA expression profiles associated with prognosis and therapeutic outcome in colon adenocarcinoma. JAMA.299(4):425-36.

95. Ji J, Shi J, Budhu A, Yu Z, Forgues M, Roessler S, et al. (2009) MicroRNA expression, survival, and response to interferon in liver cancer. The New England journal of medicine.361(15):1437-47.

96. Liu X, Liu L, Xu Q, Wu P, Zuo X, Ji A. (2012) MicroRNA as a novel drug target for cancer therapy. Expert opinion on biological therapy.12(5):573-80.

97. Porkka KP, Pfeiffer MJ, Waltering KK, Vessella RL, Tammela TL, Visakorpi T. (2007) MicroRNA expression profiling in prostate cancer. Cancer research.67(13):6130-5.

98. Catto JW, Alcaraz A, Bjartell AS, De Vere White R, Evans CP, Fussel S, et al. (2011) MicroRNA in prostate, bladder, and kidney cancer: a systematic review. Eur Urol.59(5):671-81.

99. Coppola V, De Maria R, Bonci D. (2010) MicroRNAs and prostate cancer. Endocrine-related cancer.17(1):F1-17.

100. Ozen M, Creighton CJ, Ozdemir M, Ittmann M. (2008) Widespread deregulation of microRNA expression in human prostate cancer. Oncogene.27(12):1788-93.

101. Hassan O, Ahmad A, Sethi S, Sarkar FH. (2012) Recent updates on the role of microRNAs in prostate cancer. Journal of hematology \& oncology.5:9.

102. Weber JA, Baxter DH, Zhang S, Huang DY, Huang KH, Lee MJ, et al. (2010) The microRNA spectrum in 12 body fluids. Clinical chemistry.56(11):1733-41.

103. Gordanpour A, Nam RK, Sugar L, Seth A. (2012) MicroRNAs in prostate cancer: from biomarkers to molecularly-based therapeutics. Prostate cancer and prostatic diseases.15(4):314-9.

104. Varambally S, Cao Q, Mani RS, Shankar S, Wang X, Ateeq B, et al. (2008) Genomic loss of microRNA-101 leads to overexpression of histone methyltransferase EZH2 in cancer. Science.322(5908):1695-9.

105. O'Kelly F, Marignol L, Meunier A, Lynch TH, Perry AS, Hollywood D. (2012) MicroRNAs as putative mediators of treatment response in prostate cancer. Nature reviews Urology.9(7):397-407.

106. Volinia S, Calin GA, Liu CG, Ambs S, Cimmino A, Petrocca F, et al. (2006) A microRNA expression signature of human solid tumors defines cancer gene targets. Proceedings of the National Academy of Sciences of the United States of America.103(7):2257-61. 
107. Jeronimo C, Bastian PJ, Bjartell A, Carbone GM, Catto JW, Clark SJ, et al. (2011) Epigenetics in prostate cancer: biologic and clinical relevance. Eur Urol.60(4):753-66.

108. Schramedei K, Morbt N, Pfeifer G, Lauter J, Rosolowski M, Tomm JM, et al. (2011) MicroRNA-21 targets tumor suppressor genes ANP32A and SMARCA4. Oncogene.30(26):2975-85.

109. Ribas J, Ni X, Haffner M, Wentzel EA, Salmasi AH, Chowdhury WH, et al. (2009) miR-21: an androgen receptor-regulated microRNA that promotes hormone-dependent and hormone-independent prostate cancer growth. Cancer research.69(18):7165-9.

110. Maugeri-Sacca M, Coppola V, Bonci D, De Maria R. (2012) MicroRNAs and prostate cancer: from preclinical research to translational oncology. Cancer J.18(3):253-61.

111. Aqeilan RI, Calin GA, Croce CM. (2010) miR-15a and miR-16-1 in cancer: discovery, function and future perspectives. Cell death and differentiation. 17(2):215-20.

112. Todorova K, Mincheff M, Hayrabedyan S, Mincheva J, Zasheva D, Kuzmanov A, et al. (2013) Fundamental role of microRNAs in androgen-dependent male reproductive biology and prostate cancerogenesis. Am J Reprod Immunol.69(2):100-4.

113. Bonci D, Coppola V, Musumeci M, Addario A, Giuffrida R, Memeo L, et al. (2008) The miR-15a-miR-16-1 cluster controls prostate cancer by targeting multiple oncogenic activities. Nature medicine.14(11):1271-7.

114. Lin SL, Chiang A, Chang D, Ying SY. (2008) Loss of mir-146a function in hormone-refractory prostate cancer. RNA.14(3):417-24.

115. Xu B, Wang N, Wang X, Tong N, Shao N, Tao J, et al. (2012) MiR-146a suppresses tumor growth and progression by targeting EGFR pathway and in a $p$ ERK-dependent manner in castration-resistant prostate cancer. The Prostate.72(11):1171-8.

116. Gandellini P, Folini M, Longoni N, Pennati M, Binda M, Colecchia M, et al. (2009) miR-205 Exerts tumor-suppressive functions in human prostate through down-regulation of protein kinase Cepsilon. Cancer research.69(6):2287-95.

117. Sun T, Wang Q, Balk S, Brown M, Lee GS, Kantoff P. (2009) The role of microRNA-221 and microRNA-222 in androgen-independent prostate cancer cell lines. Cancer research.69(8):3356-63.

118. Epis MR, Giles KM, Barker A, Kendrick TS, Leedman PJ. (2009) miR-331-3p regulates ERBB-2 expression and androgen receptor signaling in prostate cancer. The Journal of biological chemistry.284(37):24696-704.

119. Waltering KK, Porkka KP, Jalava SE, Urbanucci A, Kohonen PJ, Latonen LM, et al. (2011) Androgen regulation of micro-RNAs in prostate cancer. The Prostate.71(6):604-14.

120. Noonan EJ, Place RF, Pookot D, Basak S, Whitson JM, Hirata H, et al. (2009) miR-449a targets HDAC-1 and induces growth arrest in prostate cancer. Oncogene.28(14):1714-24. 
121. Weichert W, Roske A, Gekeler V, Beckers T, Stephan C, Jung K, et al. (2008) Histone deacetylases 1,2 and 3 are highly expressed in prostate cancer and HDAC2 expression is associated with shorter PSA relapse time after radical prostatectomy. British journal of cancer.98(3):604-10.

122. He L, He X, Lim LP, de Stanchina E, Xuan Z, Liang Y, et al. (2007) A microRNA component of the p53 tumour suppressor network. Nature.447(7148):1130-4.

123. Kojima K, Fujita Y, Nozawa Y, Deguchi T, Ito M. (2010) MiR-34a attenuates paclitaxel-resistance of hormone-refractory prostate cancer PC3 cells through direct and indirect mechanisms. The Prostate.70(14):1501-12.

124. Fujita Y, Kojima K, Hamada N, Ohhashi R, Akao Y, Nozawa Y, et al. (2008) Effects of miR-34a on cell growth and chemoresistance in prostate cancer PC3 cells. Biochemical and biophysical research communications.377(1):114-9.

125. Kong D, Li Y, Wang Z, Banerjee S, Ahmad A, Kim HR, et al. (2009) miR-200 regulates PDGF-D-mediated epithelial-mesenchymal transition, adhesion, and invasion of prostate cancer cells. Stem Cells.27(8):1712-21.

126. Kupcsik L. (2011) Estimation of cell number based on metabolic activity: the MTT reduction assay. Methods Mol Biol.740:13-9.

127. Sylvester PW. (2011) Optimization of the tetrazolium dye (MTT) colorimetric assay for cellular growth and viability. Methods Mol Biol.716:157-68.

128. Hansen J, Bross P. (2010) A cellular viability assay to monitor drug toxicity. Methods Mol Biol.648:303-11.

129. van Meerloo J, Kaspers GJ, Cloos J. (2011) Cell sensitivity assays: the MTT assay. Methods Mol Biol.731:237-45.

130. Schmittgen TD, Livak KJ. (2008) Analyzing real-time PCR data by the comparative C(T) method. Nature protocols.3(6):1101-8.

131. Carbon S, Ireland A, Mungall CJ, Shu S, Marshall B, Lewis S. (2009) AmiGO: online access to ontology and annotation data. Bioinformatics.25(2):288-9.

132. Boyle El, Weng S, Gollub J, Jin H, Botstein D, Cherry JM, et al. (2004) GO::TermFinder--open source software for accessing Gene Ontology information and finding significantly enriched Gene Ontology terms associated with a list of genes. Bioinformatics.20(18):3710-5.

133. Liu C, Kelnar K, Vlassov AV, Brown D, Wang J, Tang DG. (2012) Distinct microRNA expression profiles in prostate cancer stem/progenitor cells and tumor-suppressive functions of let-7. Cancer research.72(13):3393-404.

134. Liu R, Chen X, Du Y, Yao W, Shen L, Wang C, et al. (2012) Serum microRNA expression profile as a biomarker in the diagnosis and prognosis of pancreatic cancer. Clinical chemistry.58(3):610-8.

135. Sarver AL, French AJ, Borralho PM, Thayanithy V, Oberg AL, Silverstein KA, et al. (2009) Human colon cancer profiles show differential microRNA expression depending on mismatch repair status and are characteristic of undifferentiated proliferative states. BMC cancer.9:401. 
136. Wu W, Yang J, Feng X, Wang H, Ye S, Yang P, et al. (2013) MicroRNA-32 (miR-32) regulates phosphatase and tensin homologue (PTEN) expression and promotes growth, migration, and invasion in colorectal carcinoma cells. Molecular cancer.12:30.

137. Petillo D, Kort EJ, Anema J, Furge KA, Yang XJ, Teh BT. (2009) MicroRNA profiling of human kidney cancer subtypes. International journal of oncology.35(1):109-14.

138. Ambs S, Prueitt RL, Yi M, Hudson RS, Howe TM, Petrocca F, et al. (2008) Genomic profiling of microRNA and messenger RNA reveals deregulated microRNA expression in prostate cancer. Cancer research.68(15):6162-70.

139. Jalava SE, Urbanucci A, Latonen L, Waltering KK, Sahu B, Janne OA, et al. (2012) Androgen-regulated miR-32 targets BTG2 and is overexpressed in castration-resistant prostate cancer. Oncogene.31(41):4460-71.

140. Zhang L, Liu T, Huang Y, Liu J. (2011) microRNA-182 inhibits the proliferation and invasion of human lung adenocarcinoma cells through its effect on human cortical actin-associated protein. International journal of molecular medicine.28(3):381-8.

141. Kong WQ, Bai R, Liu T, Cai CL, Liu M, Li X, et al. (2012) MicroRNA-182 targets CAMP-responsive element-binding protein 1 and suppresses cell growth in human gastric adenocarcinoma. The FEBS journal.279(7):1252-60.

142. Segura MF, Hanniford D, Menendez S, Reavie L, Zou X, Alvarez-Diaz S, et al. (2009) Aberrant miR-182 expression promotes melanoma metastasis by repressing FOXO3 and microphthalmia-associated transcription factor. Proceedings of the National Academy of Sciences of the United States of America.106(6): 1814-9.

143. Liu Z, Liu J, Segura MF, Shao C, Lee P, Gong Y, et al. (2012) MiR-182 overexpression in tumourigenesis of high-grade serous ovarian carcinoma. The Journal of pathology.228(2):204-15.

144. Wang J, Li J, Shen J, Wang C, Yang L, Zhang X. (2012) MicroRNA-182 downregulates metastasis suppressor 1 and contributes to metastasis of hepatocellular carcinoma. BMC cancer.12:227.

145. Lei R, Tang J, Zhuang X, Deng R, Li G, Yu J, et al. (2013) Suppression of MIM by microRNA-182 activates RhoA and promotes breast cancer metastasis. Oncogene.

146. Guttilla IK, White BA. (2009) Coordinate regulation of FOXO1 by miR-27a, miR-96, and miR-182 in breast cancer cells. The Journal of biological chemistry.284(35):23204-16.

147. Hirata H, Ueno K, Shahryari V, Deng G, Tanaka Y, Tabatabai ZL, et al. (2013) MicroRNA-182-5p promotes cell invasion and proliferation by down regulating FOXF2, RECK and MTSS1 genes in human prostate cancer. PloS one.8(1):e55502.

148. Liu R, Li J, Teng Z, Zhang Z, Xu Y. (2013) Overexpressed MicroRNA-182 Promotes Proliferation and Invasion in Prostate Cancer PC-3 Cells by DownRegulating N-myc Downstream Regulated Gene 1 (NDRG1). PloS one.8(7):e68982. 
149. Qu Y, Li WC, Hellem MR, Rostad K, Popa M, McCormack E, et al. (2013) MiR-182 and miR-203 induce mesenchymal to epithelial transition and selfsufficiency of growth signals via repressing SNAI2 in prostate cells. International journal of cancer Journal international du cancer.133(3):544-55.

150. Rasheed SA, Teo CR, Beillard EJ, Voorhoeve PM, Casey PJ. (2013) MicroRNA182 and microRNA-200a control G-protein subunit alpha-13 (GNA13) expression and cell invasion synergistically in prostate cancer cells. The Journal of biological chemistry.288(11):7986-95.

151. Tsuchiyama K, Ito H, Taga M, Naganuma S, Oshinoya $Y$, Nagano K, et al. (2013) Expression of microRNAs associated with Gleason grading system in prostate cancer: miR-182-5p is a useful marker for high grade prostate cancer. The Prostate.73(8):827-34.

152. Neville PJ, Conti DV, Paris PL, Levin H, Catalona WJ, Suarez BK, et al. (2002) Prostate cancer aggressiveness locus on chromosome 7q32-q33 identified by linkage and allelic imbalance studies. Neoplasia.4(5):424-31.

153. Ribeiro FR, Jeronimo C, Henrique R, Fonseca D, Oliveira J, Lothe RA, et al. (2006) $8 \mathrm{q}$ gain is an independent predictor of poor survival in diagnostic needle biopsies from prostate cancer suspects. Clinical cancer research : an official journal of the American Association for Cancer Research.12(13):3961-70.

154. Szafranska AE, Davison TS, John J, Cannon T, Sipos B, Maghnouj A, et al. (2007) MicroRNA expression alterations are linked to tumorigenesis and nonneoplastic processes in pancreatic ductal adenocarcinoma. Oncogene.26(30):4442-52.

155. Ladeiro Y, Couchy G, Balabaud C, Bioulac-Sage P, Pelletier L, Rebouissou S, et al. (2008) MicroRNA profiling in hepatocellular tumors is associated with clinical features and oncogene/tumor suppressor gene mutations. Hepatology.47(6):1955-63.

156. Avissar M, Christensen BC, Kelsey KT, Marsit CJ. (2009) MicroRNA expression ratio is predictive of head and neck squamous cell carcinoma. Clinical cancer research : an official journal of the American Association for Cancer Research.15(8):2850-5.

157. Tsukamoto $Y$, Nakada C, Noguchi T, Tanigawa M, Nguyen LT, Uchida T, et al. (2010) MicroRNA-375 is downregulated in gastric carcinomas and regulates cell survival by targeting PDK1 and 14-3-3zeta. Cancer research.70(6):2339-49.

158. Ding L, Xu Y, Zhang W, Deng Y, Si M, Du Y, et al. (2010) MiR-375 frequently downregulated in gastric cancer inhibits cell proliferation by targeting JAK2. Cell research.20(7):784-93.

159. de Souza Rocha Simonini P, Breiling A, Gupta N, Malekpour M, Youns M, Omranipour R, et al. (2010) Epigenetically deregulated microRNA-375 is involved in a positive feedback loop with estrogen receptor alpha in breast cancer cells. Cancer research.70(22):9175-84.

160. Jung HM, Patel RS, Phillips BL, Wang H, Cohen DM, Reinhold WC, et al. (2013) Tumor suppressor miR-375 regulates MYC expression via repression of CIP2A coding sequence through multiple miRNA-mRNA interactions. Molecular biology of the cell.24(11):1638-48, S1-7. 
161. Szczyrba J, Nolte E, Wach S, Kremmer E, Stohr R, Hartmann A, et al. (2011) Downregulation of Sec23A protein by miRNA-375 in prostate carcinoma. Molecular cancer research : MCR.9(6):791-800.

162. Selth LA, Townley S, Gillis JL, Ochnik AM, Murti K, Macfarlane RJ, et al. (2012) Discovery of circulating microRNAs associated with human prostate cancer using a mouse model of disease. International journal of cancer Journal international du cancer.131(3):652-61.

163. Wach S, Nolte E, Szczyrba J, Stohr R, Hartmann A, Orntoft T, et al. (2012) MicroRNA profiles of prostate carcinoma detected by multiplatform microRNA screening. International journal of cancer Journal international du cancer.130(3):611-21.

164. Cheng $\mathrm{HH}$, Mitchell PS, Kroh EM, Dowell AE, Chery L, Siddiqui J, et al. (2013) Circulating microRNA Profiling Identifies a Subset of Metastatic Prostate Cancer Patients with Evidence of Cancer-Associated Hypoxia. PloS one.8(7):e69239.

165. Nguyen HC, Xie W, Yang M, Hsieh CL, Drouin S, Lee GS, et al. (2013) Expression differences of circulating microRNAs in metastatic castration resistant prostate cancer and low-risk, localized prostate cancer. The Prostate.73(4):34654.

166. Costa VL, Henrique R, Jeronimo C. (2007) Epigenetic markers for molecular detection of prostate cancer. Disease markers.23(1-2):31-41.

167. Bettendorf O, Schmidt H, Staebler A, Grobholz R, Heinecke A, Boecker W, et al. (2008) Chromosomal imbalances, loss of heterozygosity, and immunohistochemical expression of TP53, RB1, and PTEN in intraductal cancer, intraepithelial neoplasia, and invasive adenocarcinoma of the prostate. Genes, chromosomes \& cancer.47(7):565-72. 